\title{
A revision of Litsea (Lauraceae) in Peninsular Malaysia and Singapore
}

\author{
R.P.J. de Kok \\ Honorary Research Associate, Singapore Botanic Gardens, \\ National Parks Board, 1 Cluny Road, 259569 Singapore \\ rogier.dekok@yahoo.com
}

\begin{abstract}
A revision of all species of the genus Litsea Lam. (Lauraceae) occurring in Peninsular Malaysia and Singapore is presented along with a summary of taxonomic history, notable features of morphology, and a key to species. A description, distribution map, and a proposed conservation assessment is presented for each species, together with notes on ecology and ethnobotany. Through this revision, 37 distinct species are recognised. Forty-three names are lectotypified (Cylicodaphne myristicifolia (Wall. ex Nees) Meisn. var. acutata Meisn., Lepidadenia magnifica Miq., Litsea accedens (Blume) Boerl., L. acrantha Ridl., L. amara Blume, L. angulata Blume, L. artocarpifolia Gamble, L. brachystachya (Blume) Boerl., L. brideliifolia Hayata, L. cinerascens Ridl., L. costalis (Nees) Kosterm., L. curtisii Gamble, L. elliptica Blume, L. erectinervia Kosterm., L. fenestrata Gamble, L. ferruginea (Blume) Blume, L. glabrifolia Ridl., L. glutinosa (Lour.) C.B.Rob., L. helferi Hook.f. var. ovata Gamble, L. hirsutissima Gamble var. geniculata Gamble, L. kunstleri Gamble, L. lancifolia (Roxb. ex Nees) Fern.-Vill. var. rufa Ridl., L. machilifolia Gamble var. montana Ridl., L. magnifica (Miq.) Fern.-Vill. var. pahangensis Ridl., L. maingayi Hook.f., L. monopetala (Roxb.) Pers., L. noronhae Blume, L. noronhae Blume var. hexandra Gamble, L. patellaris Gamble, L. penangiana Hook.f., L. petiolata Hook.f., L. quercina Gamble, L. robusta Blume, L. scortechinii Gamble, L. sessiliflora Hook.f., L. spathacea Gamble, L. spathacea Gamble var. tomentosa Gamble, L. sphaerocarpa Blume, L. terminalis Ridl., L. ujongensis Gamble, L. ujongensis Gamble var. nervosa Gamble, Tetranthera angusta Nees and T. cordifolia Meisn.), while three additional names are lectotypified in a second step (L. lancifolia (Roxb. ex Nees) Fern.-Vill., L. monticola Gamble and L. trunciflora Gamble) and eleven names are placed into synonymy for the first time (Cylicodaphne myristicifolia (Wall. ex Nees) Meisn. var. acutata Meisn., L. cinerascens Ridl., L. firma (Blume) Hook.f., L. foxiana Gamble, L. hirsutior Kosterm., L. magnifica (Miq.) Fern.-Vill., L. paludosa Kosterm., L. persella Ridl., L. rufofusca Kosterm., L. spathacea Gamble, and L. umbellata (Lour.) Merr. var. fuscotomentosa (Meisn.) I.M.Turner). Most species have a global conservation assessment of Least Concern, while a few species are either Vulnerable (L. acrantha and L. fenestrata), Endangered (L. claviflora Gamble, L. curtisii and L. penangiana), Critically Endangered (L. ridleyi Gamble) and one species considered to be Data Deficient (L. glabrifolia Ridl.).
\end{abstract}

Keywords. Conservation assessment, lectotypification, taxonomy

\section{Introduction}

The genus Litsea Lam. was first described in 1792 based on Litsea chinensis Lam. (= L. glutinosa (Lour.) C.B.Rob., a widespread species) (Lamarck, 1792: 574). The 
genus name is most likely a Latinisation of the Chinese term for chestnuts (li tse), and this may refer to the cupule at the base of the fruits of many species, which bears a superficial resemblance to those of many species of chestnuts (Fagaceae). However, the name could also refer to the chestnut-colour of the wood, leaves and nuts upon drying. The genus is one of the largest in the Lauraceae and comprises more than 300 species that are indigenous to tropical Asia, the Pacific, Australia and North and Central America. In almost all areas of Asia where it occurs, it comprises $25-30 \%$ of all species of Lauraceae. As these trees are very common, they are often collected and consequently they form a large part of the total number of Lauraceae specimens in each herbarium.

Recent molecular studies show the genus is part of the 'core' Lauraceae group (Rohwer \& Rudolph, 2005), but the genus itself is likely to be polyphyletic and its circumscription will change in the future ( $\mathrm{Li}$ et al., 2004). Litsea differs from Lindera Thunb. only in its 4-locular anthers (2-locular in Lindera), from Iteadaphne Blume by having more than one flower per umbel, and from Neolitsea (Benth. \& Hook.f.) Merr. by the latter having dimerous flowers. Consequently, fruiting specimens or specimens with female flowers are sometimes difficult to determine to genus.

The taxonomy of Litsea is not well known and only a few regional accounts have been published. These include revisions for the floras of China (Li et al., 2008), Australia (Le Cussan \& Hyland, 2007), and for Thailand (Ngernsaengsaruay et al., 2011), with notes on the species of Borneo ( $\mathrm{Ng}, 2005)$ and Peninsular Malaysia and Singapore (De Kok, 2017).

\section{Morphology}

\section{Habit}

All species are either trees or shrubs, usually of modest height, but some can be up to $50 \mathrm{~m}$ tall, with a dbh up to $90 \mathrm{~cm}$. The bark is either smooth or slightly fissured and is usually reported to be fragrant.

\section{Leaves and bracts}

The leaves of most species are alternate with only a few species having almost exclusively sub-opposite leaves (e.g., Litsea ferruginea (Blume) Blume, L. gracilipes Hook.f., L. lanceolata (Blume) Kosterm., L. lancifolia (Roxb. ex Nees) Fern.-Vill. and L. sessiliflora Hook.f.). The bracts that are situated at the base of the axillary inflorescences are scale-like and morphologically very different from the leaves. Several different types of leaf venation are present, but most species are pinninerved.

\section{Twigs and terminal buds}

Twigs and terminal leaf buds are generally important characters in species recognition in the Lauraceae (De Kok, 2015, 2016a, 2016b) but in Litsea they are considered to be of less significance. 


\section{Indumentum}

The density of hairs on the undersurface of the leaves is a useful character in species recognition in this group. Some species have velutinous leaf surfaces, while others have completely glabrous leaves.

Two types of simple hairs are present in Litsea and these are also common in the Lauraceae in general. The first type is of appressed and whitish to yellowish or reddish brown hairs, forming a dense to very sparse covering. In young leaves the hairs are very uniformly distributed, but they become patchier when the leaves become older. The second type is of erect, yellowish to reddish brown hairs and usually forms a dense indumentum.

In one species, Litsea castanea Hook.f., yellowish scales are present on the twigs which are very distinctive for this species.

\section{Inflorescences}

Litsea has umbellate inflorescences which are placed on 'shortshoots' which can be quite long (up to $20 \mathrm{~cm}$ ) in some species thereby giving the umbel-bearing shoot the appearance of a raceme of umbels (referred to in the text as 'inflorescences with the appearance of a raceme of umbels'). However, there is always a vegetative terminal bud indicating the 'raceme' is a twig bearing umbels rather than a terminal raceme. Other species have 'shortshoots' which are very short to the point of being hardly visible, making the inflorescences look like a cluster of umbels on the twigs (referred to in the text as 'inflorescences clusters of umbels').

Only in a single species, Litsea johorensis Gamble, are the flowers and fruits borne in clusters on the main trunk; in all other species they are borne on the twigs. Where on the twigs the inflorescences are placed is important: they can be borne strictly on young twigs, in the axils of young leaves, or on older parts of the twigs, below the leaves, or in the axils of leaf scars. In many cases there is some overlap between these arrangements, making this character difficult to use in keys.

\section{Fruits}

The size and shape of the fruits are very uniform but are used for recognition of some species. The major set of identification characters are provided by the cupule, where the size, woodiness, hairiness or smoothness, and how much of it covers the fruit when mature, are major identification characters.

\section{Material and methods}

This study is based mainly on observations of herbarium specimens from the following herbaria: BM, BO, IBK, K, KEP, L, MEL, P, PE and SING.

In the following descriptions:

i) all measurements and colour descriptions are from mature material;

ii) all measurements and all statements on the position of the veins relative to the remainder of the leaf are taken from dried herbarium material; 
iii) all collections of Litsea from Peninsular Malaysia and Singapore seen by the author are cited;

iv) selected specimens from outside Peninsular Malaysia and Singapore are cited when the material was used in writing the descriptions;

v) all synonyms of Litsea taxa from Peninsular Malaysia and Singapore are included. Synonyms from outside the area are included only in those cases where the type material has been seen by the author;

vi) scans of type material were seen on http://plants.jstor.org on 25 June 2019; barcode information is given for all specimens where available;

vii) for the IUCN conservation assessment, all Extents of Occurrence (EOO) and Areas of Occupancy (AOO) were calculated using http://geocat.kew. org on 25 June 2019;

viii) the global IUCN conservation assessment follows the IUCN Standards and Petitions Committee (2019) whereas the local conservation assessment for Singapore follows Davison et al. (2008).

\section{Taxonomic treatment}

Litsea Lam., Encycl. 3: 574 (1792), nom. cons.; Jussieu, Ann. Mus. Natl. Hist. Nat. 6: 207 (1805); Jussieu in Persoon, Syn. Pl. 2(1): 4 (1806), as 'Litsaea'; Blume, Mus. Bot. 1: 345 (1851), as 'Litsaea'; Meisner in DC., Prodr. 15: 220 (1864); Hooker, Fl. Brit. India 5: 155 (1886); Lecomte, Nouv. Arch. Mus. Hist. Nat., ser. 5, 5: 82 (1913); Lecomte, Fl. Indo-Chine 5: 130 (1914); Ridley, Fl. Malay Penins. 3: 112 (1924); Liou Ho, Laurac. Chine \& Indochine 162 (1932); Corner, Wayside Trees Mal. 347 (1940); Allen, J. Arnold Arbor. 26: 406 (1945); Kostermans, Reinwardtia 4: 240 (1957); Backer \& Bakhuizen van den Brink, Fl. Java (Spermatoph.) 1: 125 (1963); Kochummen in Ng, Tree Fl. Malaya 4: 149 (1989); Rohwer in Kubitzki, Fam. Gen. Vasc. P1. 2: 388 (1993); Kostermans, Revis. Handb. Fl. Ceylon 9: 145 (1995); Van der Werff, Blumea 46: 137 (2001); Ngernsaengsaruay et al., Thai Forest Bull., Bot. 39: 40 (2011). - TYPE: Litsea chinensis Lam. (= Litsea glutinosa (Lour.) C.B.Rob.).

Trees or shrubs; dioecious. Terminal leaf buds usually not perulate at maturity. Leaves alternate or rarely (sub)opposite, sometimes crowded towards the apex of branchlets, usually aromatic when crushed; blades pinnately veined. Inflorescences umbellate, usually forming clusters of umbels, or sometimes with the appearance of a short or long raceme of umbels, or sometimes umbels solitary, in the axils of leaves or along branchlets, sometimes at the apex of branchlets or rarely borne on the trunk (not in Singapore) or on leafless branches; involucral bracts surrounding the flowers 4-5(-6). Flowers unisexual, 3-8(-16) in each umbel, perianth lobes $(0-) 6(-12)$, in $(0-) 2(-4)$ whorls of 3, membranaceous, subequal. Male flowers: stamens (6-)9-12(-30) in (2)3-4(-10) whorls of 3, anthers 4-celled; the outer 2 whorls of filaments without glands, the third and inner whorls (when present) with 2 glands at or near the base; pistillode present or absent. Female flowers: ovary usually enclosed in the perianth tube, stigma 
peltate; staminodes equal in number to the stamens in male flowers or almost so, the outer 2 whorls without glands, the third and inner whorls (when present) with 2 glands at or near base. Fruit a one-seeded berry seated on the enlarged perianth tube (cupule), usually aromatic when crushed; cupule shallow or deeply cup-shaped, partly enclosing the fruit; stalk more or less thickened, or rarely fruits subsessile or sessile.

Distribution. About 350 species in tropical Asia, Australia, the western Pacific, and North and Central America. In Peninsular Malaysia and Singapore 37 species are recognised of which seven are endemic to this region and one, from Singapore, is insufficiently known.

Uses. Species of this genus are not known to be extensively used by local people in this region. From information on herbarium specimens, only one is mentioned as a good timber tree (Litsea gracilipes), while another is occasionally planted (L. glutinosa) and one species is said to be used medicinally (L. elliptica Blume).

Notes. The Indian, southern Chinese and Indo-Chinese species Litsea salicifolia (Roxb. ex Nees) Hook.f. is reported from the Gardens' Jungle of the Singapore Botanic Gardens (Ridley, 1900: 132). This is most likely a misidentification of Litsea umbellata (Lour.) Merr.

Ridley (1900: 132) also lists Litsea nitida Blume from Bukit Mandai in Singapore. I could not find any record that this name has been published and is likely a misidentification of another species of Litsea.

\section{Key to species of Litsea}

(Species of this genus are not blessed with many distinctive characters and most species are defined by unique combinations of characters. Consequently, some leads in the key unavoidably have slightly overlapping characters and on rare occasions the user may be forced to follow both leads to possible species and compare the specimen with the full descriptions of each.)

1a. Flowers and fruits borne in clusters on the main trunk 21. L.johorensis

1b. Flowers and fruits borne in clusters on the twigs 2

2a. Leaves (sub)opposite .................................................................................. 3

2b. Leaves alternate .................................................................................... 7

3a. Lower leaf surface sparsely to densely hairy, with dark or reddish brown hairs ...

3b. Lower leaf surface glabrous to sparsely hairy, with white to yellowish hairs ..... 5 
4a. Tree 6-25 $\mathrm{m}$ tall, dbh 26-90 cm; leaf apex acute to rounded, base cuneate, secondary veins $8-12$ pairs, looping near the margin; petiole swollen at the base .. 15. L. ferruginea

4b. Shrub or tree 1.5-6 m tall, dbh 5-12 cm; leaf apex acuminate, often with a sharp tip, base rounded or broadly cuneate, secondary veins 13-20 pairs, curving near the margin; petiole (slightly) swollen 34. L. sessiliflora

5a. Young twigs glabrous; leaf apex acute to sharply acute, often with a distinct tip .. .. 18. L. gracilipes

5b. Young twigs densely hairy; leaf apex acute to (shortly) acuminate 6

6a. Leaf apex acuminate with the tip 1-2.7 $\mathrm{mm}$ long; blade drying reddish brown, secondary veins clearly brochidodromous 22. L. lanceolata

6b. Leaf apex acute to short acuminate, sometimes with a long tip; blade drying greenish brown, secondary veins obscurely brochidodromous ...... 23. L. lancifolia

7a. Leaf base cordate 9. L. cordata

7b. Leaf base attenuate, cuneate or rounded .8

8a. Leaves hairy below 9

8 b. Leaves glabrous below 24

9a. Leaf surface below with dark or reddish brown hairs 10

9b. Leaf surface below with yellowish to light brown hairs 12

10a. Tree 5-30(-40) $\mathrm{m}$ tall; cupule woody and warty, covering up to half of the fruit .. 13. L. erectinervia

10b. Tree or shrub $1-5(-10) \mathrm{m}$ tall; cupule papery, smooth and velutinous, covering only the lower part of the fruit 11

11a. Leaves and twigs with curly hairs; leaf apex rounded to acute, sometimes acuminate, secondary veins $6-11$ pairs

2. L. acrantha

11b. Leaves and twigs with erect hairs, leaf apex acute to acuminate, always with a sharp tip, secondary veins 9-18 pairs 20. L. hirsutissima

12a. Inflorescences with the appearance of a raceme of umbels, 5-20 cm long 13

12b. Inflorescences clusters of umbels, $0.5-4.4 \mathrm{~cm}$ long 14

13a. Tree well-branched; twigs densely appressed hairy when young; leaf apex rounded to acute, sometimes with a very short tip; upper surface of blade glabrous; male flowers with perianth lobes 1.5-2 × 0.8-1 mm, apices acute; stamens 12, 13, 14 or 15 ; fruits globose, $10-27 \times 10-20 \mathrm{~mm}$ 32. L. robusta

13b. Tree monopodial; twigs velutinous with erect, curly hairs when young; leaf apex rounded to slightly emarginate; upper surface of blade glabrous, apart from 
densely hairy midrib; male flowers with perianth lobes $3.8-4.2 \times 1-1.2 \mathrm{~mm}$, apices acuminate; stamens 9 or 12; fruits ellipsoid, 33-50 $\times 20-30 \mathrm{~mm}$

4. L. artocarpifolia

14a. Leaves crowded at the apices of the twigs; petioles $10-55 \mathrm{~mm}$ long

36. L. tomentosa

14b. Leaves usually spaced along the twigs, rarely crowded at the apices of the twigs; petioles $8-25(-32) \mathrm{mm}$ long

15a. Terminal leaf bud 8-19 mm long (sequentially follow each lead if 8-12 $\mathrm{mm}$ long)

15b. Terminal leaf bud 2-12 $\mathrm{mm}$ long (follow this lead if 8-12 $\mathrm{mm}$ long and no match found in previous lead) 18

16a. Cupule at first completely enclosing fruit with a circular orifice, later covering only the lower half, glabrous; fruit stalk swollen 14. L. fenestrata

16b. Cupule shallow, never fully enclosing the fruit, sparsely pubescent; fruit stalk slightly swollen 17

17a. Leaves leathery, margins often wavy; tertiary veins prominent on both surfaces .. 19. L. grandis

17b. Leaves thinly leathery, margins flat; tertiary veins indistinct on both surfaces 11. L. curtisii

18a. Twigs glabrous to sparsely hairy when young 19

$18 \mathrm{~b}$. Twigs velutinous or densely hairy when young 20

19a. Terminal leaf bud lanceolate with acute apex; tertiary veins distinct on lower surface of the blade 26. L. monopetala

19b. Terminal leaf bud ovoid with acuminate apex; tertiary veins indistinct on lower surface of the blade 16. L. glabrifolia

20a. Cupule woody and warty, $8-10 \times 12-14 \mathrm{~mm}$, margins entire to lobed, covering the whole fruit when young to only the lower $1 / 3$ when mature ..... 29. L. penangiana

20b. Cupule membranous and smooth, 1.4-7.2 $\times 3-15 \mathrm{~mm}$, margins entire, covering only the lower part of the fruit

21a. Inflorescence 2-6 cm long, umbels with 9-15 flowers, 4-15 $\mathrm{mm}$ in diameter; bracts $3.5-7 \times 3-7 \mathrm{~mm}$, densely hairy outside; fruits $7-10 \times 10-12 \mathrm{~mm}$

17. L. glutinosa

21b. Inflorescence $0.5-4 \mathrm{~cm}$ long, umbels with 3-8 flowers, 2-7.5 $\mathrm{mm}$ in diameter; bracts $2-6.5 \times 2-6 \mathrm{~mm}$, sparsely to densely hairy outside; fruits $2.5-20 \mathrm{~mm}$ diameter 
22a. Twigs densely hairy when young, glabrescent; leaf surface above glabrous with a few hairs on midrib; inflorescences clusters of umbels 1-4 cm long; bracts 5-6.5 $\times 5-6 \mathrm{~mm}$; fruits $15-20 \times 11-14 \mathrm{~mm}$, apex acute, red or purplish when mature; cupule 13-15 $\mathrm{mm}$ in diameter, 5-7.2 $\mathrm{mm}$ high, glabrous ....... 35. L. sphaerocarpa

$22 \mathrm{~b}$. Twigs densely hairy to velutinous when young; leaf surface above glabrous to sparsely hairy, but midrib densely hairy or indumentum denser on and along the midrib and secondary veins; inflorescences clusters of umbels $0.1-2 \mathrm{~cm}$ long; bracts $2-4.5 \times 2-4 \mathrm{~mm}$; fruits $2.5-14 \times 0.6-2 \mathrm{~mm}$, apex rounded, dark red-purple or black when mature; cupule 3-8 $\mathrm{mm}$ in diameter, 1.4-3.6 $\mathrm{mm}$ high, glabrous or sparsely hairy 23

23a. Secondary veins more or less same colour as the blade on the lower surface, 5-17 pairs, curving towards the margin at a $45-90^{\circ}$ angle at base with midrib; fruits $2.5-10 \times 0.6-2 \mathrm{~cm}$ 37. L. umbellata

$23 \mathrm{~b}$. Secondary veins sharply contrasting in colour with the blade on the lower surface, 5-7 pairs, curving towards the margin at about a $45^{\circ}$ angle at base with midrib; fruits $1.3-1.4 \mathrm{~cm}$ in diameter 31. L. ridleyi

24a. Young twigs covered with yellowish scales, sometimes with a dense layer of short hairs 6. L. castanea

24b. Young twigs without scales, glabrous to densely hairy 25

25a. Terminal leaf bud glabrous 26

$25 \mathrm{~b}$. Terminal leaf bud velutinous or densely hairy 27

26a. Inflorescences appearing as short or long racemes of umbels, 2.5-10 cm long; leaf apex acuminate, often with a 10-20 mm long tip; secondary venation brochidodromous 24. L. machilifolia

26b. Inflorescences clusters of umbels, 1-2.8 cm long; leaf apex acute or obtuse; secondary venation not brochidodromous 27. L. myristicifolia

$27 \mathrm{a}$. Inflorescences with the appearance of a raceme of umbels, $0.3-20 \mathrm{~cm}$ long ...... 28 $27 \mathrm{~b}$. Inflorescences clusters of umbels $0.1-4.4 \mathrm{~cm}$ long 33

28a. Leaf apex acuminate with a distinct tip; midrib above raised to flattened 25. L. maingayi

28 b. Leaf apex rounded to acute or acuminate, rarely with a very short tip; midrib above sunken ... 29

29a. Petiole $\leq 12 \mathrm{~mm}$ long, if petiole $12 \mathrm{~mm}$ long then twigs velutinous

8. L. claviflora

29b. Petiole 12-70 $\mathrm{mm}$ long, if petiole $12 \mathrm{~mm}$ long, then twigs glabrous to densely hairy 
30a. Twigs densely hairy when young, terminal leaf bud 9-15 mm long; petiole slightly swollen, glabrous; cupule woody, 17-28 $\mathrm{mm}$ in diameter, patent to covering at least half of the mature fruit

32. L. robusta

30b. Twigs glabrous to sparsely hairy when young; terminal leaf bud 2.4-10 mm long; petiole slender to swollen, glabrous to sparsely hairy; cupule membranous or fleshy, 2.3-28 $\mathrm{mm}$ in diameter, shallow or covering only the base of the fruit when mature 31

31a. Trees; terminal leaf bud 5-10 mm long; petiole slender, glabrous ... 10. L. costalis 31b. Trees or shrubs; terminal leaf bud 2.4-4.5 mm long; petiole slender to swollen, glabrous to sparsely hairy

32a. Tree 12-30 m tall; twigs glabrous; leaves elliptc or elliptic-ovate; petiole slender, glabrous 5. L. brachystachya

32b. Tree or shrub, 6-15 m tall; twigs sparsely hairy; leaves oblanceolate; petiole swollen, sparsely hairy 28. L. noronhae

33a. Inflorescences, infructescences and bracts glabrous 34

33b. Inflorescences, infructescences and bracts hairy 35

34a. Twigs glabrous, sometimes with patches of hairs; leaves with 4-10 pairs of yellow secondary veins when dried; flowers 5-6 in each umbel; stamens 9-12; fruits globose to ellipsoid, $7-11 \times 6-7 \mathrm{~mm}$; cupule $2.6-5 \times 0-2 \mathrm{~mm}$..... 12. L. elliptica

$34 \mathrm{~b}$. Twigs densely hairy when young, quickly becoming glabrous; leaves with 5-7 pairs of greenish secondary veins when dried; flowers c. 7 in each umbel; stamens 6-9; fruits globose, 12-15 × 10-12 mm; cupule 7-10 × 1.5-3 mm

33. L. rubicunda

35a. Twigs glabrous when young; mature fruit with a short beak 1. L. accedens

35b. Twigs velutinous, densely to sparsely hairy when young; mature fruits acute, truncated or rounded at the apex 36

36a. Fruit cupule woody, warty, margins entire to lobed, covering whole fruit when young to only the lower $1 / 3$ when mature 29. L. penangiana

36b. Fruit cupule woody to membranous, smooth, margins entire to undulating, covering only base of fruit at most 37

37a. Twigs velutinous when young; terminal leaf bud 3.3-4.5 mm long, apex rounded 30. L. resinosa

$37 \mathrm{~b}$. Twigs sparsely hairy when young; terminal leaf bud $4.2-5.5 \mathrm{~mm}$ long, apex acute to acuminate 38

38a. Leaf apex obtuse to acute, lamina membranous to thinly leathery; fruit apex acute; fruiting stalk slightly swollen, 1.7-2.6 mm thick, densely to sparsely hairy 
38b. Leaf apex acute to acuminate, lamina leathery; fruit apex rounded to bluntly pointed; fruiting stalk slightly to strongly swollen, 2-6 mm thick, glabrous to sparsely hairy 39

39a. Tree or shrub 5-8 $\mathrm{m}$ tall; leaves with 5-6 pairs of secondary veins and distinct tertiary veins; petioles 6-15 mm long; inflorescences in axils of leaves; fruits globose, apex rounded 7. L. chewii

39b. Tree 12-18 m tall; leaves with 7-12 pairs of secondary veins and obscure tertiary veins; petioles 10-25 mm long; inflorescences on young twigs below the leaves; fruits ellipsoid, apex bluntly pointed 3. L. angulata

1. Litsea accedens (Blume) Boerl., Handl. Fl. Ned. Ind. 3: 145 (1900); Keng, Concise Fl. Singapore, vol. 1, Gymn. Dicot. 19 (1990); Ng, Gard. Bull. Singapore 57: 222 (2005). - Tetranthera accedens Blume, Mus. Bot. 1: 383 (1851). - TYPE: [Indonesia], Celebes [Sulawesi], Tondano, July 1840, Forsten s.n. (lectotype L [L0036569], designated by De Kok, Gard. Bull. Singapore 69: 173 (2017); isolectotypes L [L0036568, L0036570]). (Fig. 1).

Cylicodaphne costata Blume, Mus. Bot. 2(1): 13 (1856). - Litsea costata (Blume) Boerl., Handl. Fl. Ned. Ind. 3: 144 (1900); Kochummen in Ng, Tree Fl. Malaya 4: 154 (1989); Keng, Concise Fl. Singapore, vol. 1, Gymn. Dicot. 19 (1990). - TYPE: [Borneo], Korthals s.n. (lectotype L [L0036657], designated by Ng, Gard. Bull. Singapore 57: 222 (2005)).

Cylicodaphne ochracea Blume, Mus. Bot. 2(1): 13 (1856). - Litsea ochracea (Blume) Boerl., Handl. Fl. Ned. Ind. 3: 144 (1900); Gamble, J. Asiat. Soc. Bengal, Pt. 2, Nat. Hist. 75(1): 165 (1912); Ridley, Fl. Malay Penins. 3: 124 (1924); Kochummen in Ng, Tree Fl. Malaya 4: 162 (1989); Ng, Gard. Bull. Singapore 57: 222 (2005); Ngernsaengsaruay et al., Thai Forest Bull., Bot. 39: 82 (2011). - TYPE: [Indonesia], Sumatra, Korthals s.n. (lectotype K [K000815292], designated by Ng, Gard. Bull. Singapore 57: 222 (2005); isolectotype U [U0002834]).

Litsea singaporensis Gamble, Bull. Misc. Inform. Kew 1910: 358 (1910); Ridley, F1. Malay Penins. 3: 122 (1924); Keng, Concise F1. Singapore, vol. 1, Gymn. Dicot. 19 (1990). - TYPE: [Singapore], Gardens' Jungle, November 1892, Ridley 4135 (lectotype K [no barcode], designated by De Kok, Gard. Bull. Singapore 69: 176 (2017); isolectotypes BM [no barcode], SING [SING0000630]).

Litsea kunstleri Gamble, Bull. Misc. Inform. Kew 1910: 363 (1910); Ridley, F1. Malay Penins. 3: 125 (1924); Kochummen in Ng, Tree Fl. Malaya 4: 154 (1989). - TYPE: [Peninsular Malaysia], Perak, Gunung Pondo, April 1885, King's Collector 7527 (lectotype K [K000797074], designated here; isolectotypes BM [BM000799098], K [K000797073], P [P00745294]). 
Litsea perakensis Gamble, Bull. Misc. Inform. Kew 1910: 359 (1910); Ridley, Fl. Malay Penins. 3: 122 (1924); Kochummen in Ng, Tree Fl. Malaya 4: 154 (1989); Keng, Concise Fl. Singapore, vol. 1, Gymn. Dicot. 19 (1990). - TYPE: [Peninsular Malaysia], Perak, Larut, November 1883, King's Collector 5114 (lectotype K [K 000797091], designated by Ng, Gard. Bull. Singapore 57: 224 (2005); isolectotypes BM [BM000799063], E [E00393258], P [P00745239]).

Litsea patellaris Gamble, Bull. Misc. Inform. Kew 1910: 360 (1910); Ridley, Fl. Malay Penins. 3: 123 (1924); Kochummen in Ng, Tree Fl. Malaya 4: 154 (1989). TYPE: [Peninsular Malaysia], Perak, near Larut, February 1885, King 's Collector 7312 (lectotype K [K000797088], designated here; isolectotype BM [BM000799050]).

Litsea pustulata Gamble, Bull. Misc. Inform. Kew 1910: 359 (1910); Ridley, Fl. Malay Penins. 3: 122 (1924); Kochummen in Ng, Tree Fl. Malaya 4: 154 (1989). TYPE: [Peninsular Malaysia], Perak, Larut, November 1883, King's Collector 5140 (lectotype K [K0000797089], designated by De Kok, Gard. Bull. Singapore 69: 175 (2017); isolectotypes BM [BM000799104], K [no barcode]).

Litsea wrayi Gamble, Bull. Misc. Inform. Kew 1910: 319 (1910); Ridley, Fl. Malay Penins. 3: 122 (1924). - TYPE: [Peninsular Malaysia], Perak, Waterfall Hill, April 1892, Wray 4036 (lectotype SING [SING0055987], designated by Ng, Gard. Bull. Singapore 57: 224 (2005); isolectotype K [K000797094]).

Litsea oblanceolata Gamble, Bull. Misc. Inform. Kew 1910: 362 (1910); Ridley, F1. Malay Penins. 3: 125 (1924); Kochummen in Ng, Tree Fl. Malaya 4: 162 (1989). - Litsea ochracea (Blume) Boerl. var. oblanceolata (Gamble) Kochummen ex I.M.Turner, Novon 6: 222 (1996). - Litsea accedens (Blume) Boerl. var. oblanceolata (Gamble) Ng, Gard. Bull. Singapore 57: 224 (2005). - TYPE: [Peninsular Malaysia], Perak, Larut, July 1881, King's Collector 2020 (lectotype K [K000797076], designated by Turner, Novon 6: 222 (1996); isolectotypes BM [BM000799118], E [E00393259], $\mathrm{P}[\mathrm{P} 00745242])$.

Litsea penangiana auct. non Hook.f.: Ridley, J. Straits Branch Roy. Asiat. Soc. 33: 131 (1900); Ridley, Fl. Malay Penins. 3: 121 (1924).

Tree 3-24 m tall, dbh 5-10 cm; bark red to (greyish) brown, smooth to finely scaly; wood pale yellow to white, aromatic. Twigs slender, $2.7-5 \mathrm{~mm}$ thick, round to angular in cross-section, glabrous; terminal leaf bud elliptic, 5-8.6 mm long, apex acute to acuminate, velutinous; hairs appressed, yellow. Leaves alternate; leaf blade leathery, elliptic to lanceolate, sometimes obovate, 7-35 × 3-12 cm, apex obtuse to sharply acute, base cuneate to attenuate, often slightly asymmetric, drying dark to light brown or green; secondary veins 7-14 pairs, curved from the margin, sometimes brochidodromous; tertiary veins reticulate, occasionally with a few scalariform veins; surface above glabrous, main vein and secondary veins flattened to sunken or sometimes slightly raised at base, tertiary veins distinct, dark green, glossy; surface 

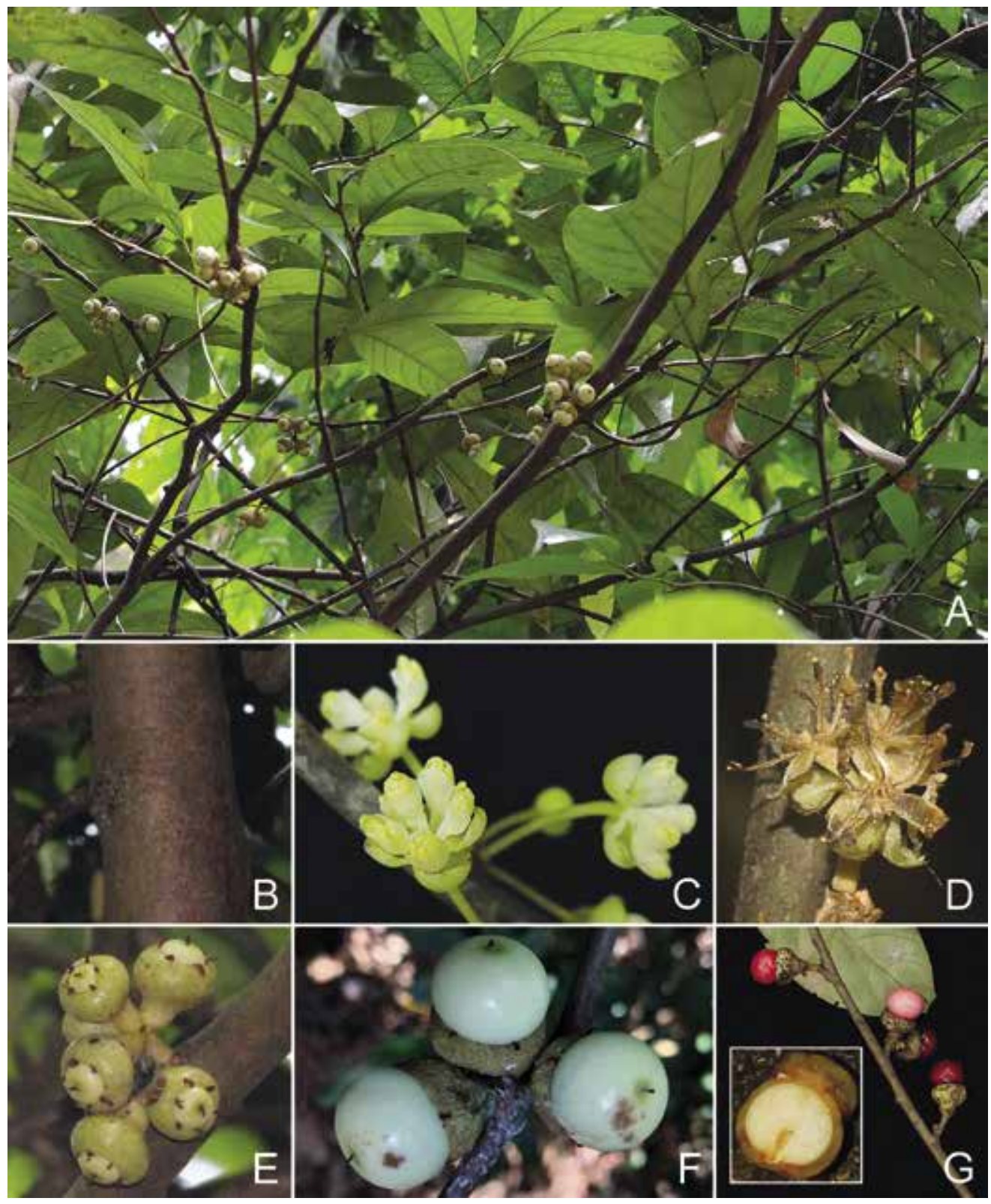

Fig. 1. Litsea accedens (Blume) Boerl. A. Habit. B. Trunk. C. Newly open flowers. D. Flower past anthesis. E. Young developing fruits. F. Unripe fruits. G. Ripened fruits. Inset: Cross-section of fruit and cupule. From Singapore; A from Bukit Timah Nature Reserve (BTNR), Niissalo et al. SING2019-563; B \& F, from BTNR, Lim et al. SING2018-731; C from MacRitchie, Leong et al. MR 2015-014; D from MacRitchie, Lua et al. SING2018-420; E from BTNR; G from MacRitchie, Lua SING2014-253. (Photos: A, C \& G, P.K.F. Leong; B, D-F, X.Y. Ng). 
below glabrous with a few hairs along the midrib, midrib and secondary veins raised, tertiary veins distinct, pale green-white, glaucescent; petiole half-terete, $12-30 \mathrm{~mm}$ long, glabrous, slightly swollen, wrinkled, black. Inflorescences clusters of umbels, $1-2.6 \mathrm{~cm}$ long, arranged along branchlets or in axils of leaves; umbels $1-1.2 \mathrm{~cm}$ in diameter, 3-6 flowers per umbel; bracts 4-5, imbricate, suborbicular to broadly ovate, concave, 4-7 $\times 3-5 \mathrm{~mm}$, coriaceous, hairy outside, glabrous inside, brown to brownish green; infructescence 1-2 cm long, with 1-4 fruits. Flowers yellowish white to yellow, lightly scented; male flowers 4-6 in each umbel, perianth lobes 6, linear-oblong, 2-5 $\times 0.8-2.2 \mathrm{~mm}$, densely to sparsely hairy, stamens light yellow, 9-16, unequal, 1.5-3 $\mathrm{mm}$ long, with a few hairs along the filaments, anthers 1-2 mm long, yellow; female flowers 4-6 in each umbel, perianth lobes 6 , elliptic to oblanceolate, $1.5-2.5 \times 0.8-1.2$ $\mathrm{mm}$, sparsely hairy, ovary ellipsoid, $0.8-1.2 \times 1-1.2 \mathrm{~mm}$, glabrous, style $1-2 \mathrm{~mm}$ long, stigma peltate. Fruits globose, 10-16 $\times 9-15 \mathrm{~mm}$, apex with a very short beak, surface smooth, glabrous, red when mature, glossy, smelling of cinnamon; cupule shallow, 10-18 $\mathrm{mm}$ in diameter, 5.3-7.3 $\mathrm{mm}$ deep, woody, margins entire with a few small remnants of the perianth lobes, covering up to half of the fruit, surface warty, dark green to straw-coloured; stalk 4-12 mm long, slightly swollen, pustulate.

Distribution. Peninsular Thailand, Peninsular Malaysia, Singapore, Sumatra and Borneo (see Fig. 2).

Ecology. Growing in lowland and hill forests, sometimes in swamps, from 0-600 m altitude. Flowering from December to May; fruiting from March to October.

Provisional IUCN conservation assessment. This species is known from numerous localities and has a very large extent of occurrence (EOO of 2,677,268 $\mathrm{km}^{2}$ ) and area of occupancy (AOO of $544 \mathrm{~km}^{2}$ ). Given this wide distribution and the number of localities from which it is known, an assessment of globally Least Concern is proposed.

Specimens examined. PENINSULAR MALAYSIA: Kedah: Koh Mai F.R., 7 Apr 1938, Kiah SFN 35208 (K). Perak: Larut, Jun 1881, King's Collector 1952 (K [2 sheets]); ibidem, Nov 1883, King's Collector 5114 (BM, K [2 sheets]); ibidem, Mar 1884, King's Collector 5666 (K [3 sheets]); ibidem, Dec 1884, King's Collector 6908 (BM, K [3 sheets]); ibidem, May 1885, King's Collector 7369 (K); Goping, May 1884, King's Collector 6069 (K [2 sheets], SING); ibidem, Apr 1884, King's Collector 5959 (K [3 sheets]); Gunong Bubu, Chew CWL 1208 (K); Wales Tall Hill, May 1888, Wray 1853 (K [2 sheets]); Sungai Krian estate, 23 Jan 1935, Spare SFN 34478 (SING [2 sheets]). Selangor: Ampang catchment area, 2 Mar 1982, Kochummen FRI 29465 (K). Johor: s.l., 10 Aug 1931, Holttum 24966 (BM, K); Sungai Berassau, MawaiJemaluang Road, 7 Feb 1935, Corner SFN 28973 (K [2 sheets], KEP); ibidem, 28 Apr 1935, Corner SFN 28993 (K [2 sheets]); ibidem, 6 Feb 1935, Corner SFN 29233 (K); ibidem, 28 Apr 1935, Corner SFN 29292 (K [2 sheets], KEP); ibidem, 28 Apr 1935, Corner SFN 29293 (KEP); Mawai, 9 Jan 1938, Ngadiman SFN 34709 (BM, K, SING [2 sheets]).

SINGAPORE: s.l., Ridley s.n. (BM); Botanic Garden, 14 Aug 1893, Ridley s.n. (K); Arboretum, 1 Mar 1918, Nur SFN 1451 (SING); Gardens Jungle, 1894, Ridley 6268 (BM, SING); Botanical Gardens' Jungle, Liane Road, 22 Jul 1955, Sinclair SFN 40679 (K, SING); Changi, 1892, Ridley 3803 (K, SING); Bukit Mandai, 1891, Ridley 4701 (K, BM [2 sheets]); 


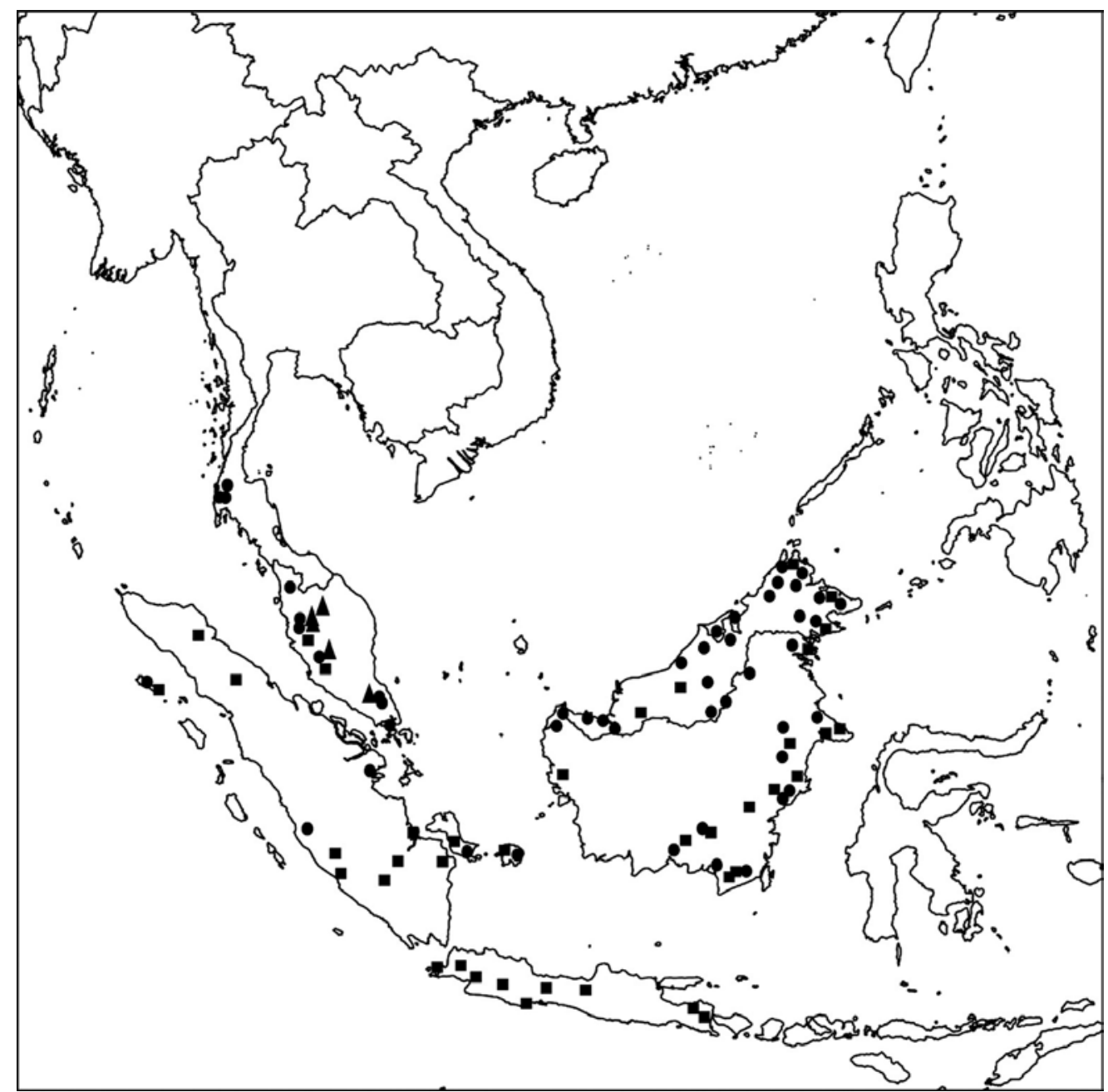

Fig. 2. Distribution of Litsea accedens $(\bullet)$, L. acrantha $(\boldsymbol{\Delta})$ and L. angulata ($(\mathbf{\square})$.

ibidem, 1892, Ridley 3836 (K, SING); ibidem, 1894, Ridley 5852 (K); ibidem, 1892, Ridley 4781 (SING); ibidem, 1893, Goodenough 5064 (BM, SING); Seletar Reservoir, Upper Mandai, 22 Aug 1953, Sinclair SFN 39998 (K); Bukit Timah, Mar 1909, Ridley 14135 (BM, K [2 sheets], SING); ibidem, 20 Sep 1890, Ridley s.n. (BM); ibidem, 3 Mar 1977, Ahmad SA 1436 (SING); ibidem, Ridley s.n. (SING); ibidem, 27 Jul 2018, Lim et al. SING2018-731 (SING); ibidem, Main Road Path, 11 Jun 2019, Niissalo et al. SING2019-563 (SING); MacRitchie Reservoir, 16 Jul 1937, Corner s.n. (SING); MacRitchie F.R., 11 Jul 2014, Lua SING2014-253 (SING); ibidem, 6 Jan 2015, Leong et al. MR 2015-004 (SING); ibidem, 17 Mar 2015, Leong et al. MR 2015-014 (SING); ibidem, between Sime Track and Petaling Boardwalk, 24 Apr 2018, Lua et al. SING2018-420 (SING); Tanglin, 1897, Ridley s.n. (BM).

Notes. In his notes on the Borneo species, Ng (2005: 222) recognised three varieties of Litsea accedens. One variety (Litsea accedens var. kinabaluensis (Kosterm.) $\mathrm{Ng}$ ) is restricted to Mt Kinabalu in Sabah, while the other two (L. accedens var. accedens and L. accedens var. oblanceolata (Gamble) $\mathrm{Ng}$ ) are more widespread. 
The differences between these two latter taxa are said to be that the type variety has reticulate intercostal venation and the leaves are elliptic or oblong-elliptic to obovate and lanceolate, whereas Litsea accedens var. oblanceolata has scalariform intercostal venation and the leaves are oblanceolate. However, among the Peninsular Malaysian and Singaporean specimens, I could not distinguish these two taxa. The variation in intercostal (tertiary) venation varies from reticulate to scalariform regardless of the shape of the leaves, and while the shape of the leaves is variable, even in the small number of specimens which have oblanceolate leaves, it is common to find on the same sheet some leaves that are more elliptic.

In the original description of Litsea kunstleri by Gamble (1910b: 363), two gatherings are mentioned: King's Collector 7527 and 7670 . There are morphologically very similar specimens of these gatherings in several herbaria (BM, E, K and P). One of the K specimens [K000797074] is designated here as the lectotype.

In the original description of Litsea patellaris by Gamble (1910b: 360), only one gathering is mentioned: King's Collector 7312. The K specimen of this gathering [K000797088] is designated here as the lectotype.

2. Litsea acrantha Ridl., J. Fed. Malay States Mus. 10: 152 (1920); Ridley, Fl. Malay Penins. 3: 123 (1924); Kochummen in Ng, Tree Fl. Malaya 4: 15 (1989). - TYPE: [Peninsular Malaysia], Kedah-Perak border, Gunung Bintang, June 1917, Native Collector FMS Museum s.n. (lectotype K [K000797079], designated here).

Litsea terminalis Ridl., Fl. Malay Penins. 5: 330 (1925); Kochummen in Ng, Tree Fl. Malaya 4: 151 (1989). - TYPE: [Peninsular Malaysia], Perak, Gunung Inas, 19 December 1899, Yapp 494 (lectotype K [K000797080], designated here).

\section{Litsea sp. '4', Kochummen in Ng, Tree Fl. Malaya 4: 167 (1989).}

Tree or shrub 2-5 m tall, dbh c. $15 \mathrm{~cm}$; bark brown. Twigs slender 2.5-5.7 mm thick, round to angled in cross-section, velutinous; hairs dark or reddish brown, curly; terminal leaf bud ovate, 3-7.3 mm long, apex acute, velutinous. Leaves alternate or spirally arranged; leaf blade leathery, elliptic to oblong or ovate, 3.5-12.5 $\times 2.2-7.2$ $\mathrm{cm}$, apex rounded to acute, sometimes acuminate, base cuneate to rounded, drying brownish; secondary veins 6-11 pairs, arching gradually towards the margin; tertiary veins scalariform-reticulate; hairs reddish to dark brown, curly; surface above glabrous except densely hairy on the main vein, main vein sunken to raised, secondary veins raised to flattened, tertiary veins distinct; surface below sparsely hairy (hairs reddish to dark brown), main vein and secondary veins raised, tertiary veins distinct; petiole halfterete, 4.4-17 mm long, slender or only (slightly) swollen, sometimes only at base, velutinous (hairs dark brown, curly). Inflorescences with the appearance of racemes of umbels, 1-8 cm long, terminal or in the axils of leaves or along the branchlets; hairs reddish brown, curly; umbels $0.3-0.9 \mathrm{~cm}$ in diameter; bracts $4-5$, suborbicular, concave, 3.3-5.7 × 3.2-4.6 mm, velutinous; infructescence with 1-10 fruits. Flowers white to yellowish green; male flowers few in each umbel, perianth lobes 6 , oblong, 
3-3.6 × 1.3-1.4 mm, apex rounded, hairy outside and inside, stamens 9-12, unequal, 3.6-4.5 mm long, sparsely hairy, anthers $0.6-1 \mathrm{~mm}$ long; female flowers c. 4 in each umbel, perianth lobes 6 , oblong, $2.7-2.9 \times 1.3-1.8 \mathrm{~mm}$, hairy outside and inside, ovary ellipsoid, 1-1.4 mm in diameter, glabrous, style 1-1.8 mm long, stigma minute. Fruits ellipsoid, 8-15 × 5-10 mm, apex acute, surface smooth, glabrous; cupule papery, 5-6 $\mathrm{mm}$ in diameter, 2-3 $\mathrm{mm}$ deep, covering only lower part of fruit, velutinous; stalk velutinous, 2-3 mm long, $1.5-1.8 \mathrm{~mm}$ thick.

Distribution. Endemic to Peninsular Malaysia, where it is recorded from Kedah, Kelantan, Perak, Pahang and Johor (see Fig. 2).

Ecology. Growing in primary and secondary montane forests, sometimes on peaty soil, at 1000-2100 m altitude. Flowering from April to November; fruiting in January.

Provisional IUCN conservation assessment. This species is only known from about eight localities and has a relatively small extent of occurrence (EOO of 31,318 $\mathrm{km}^{2}$ ) and a small area of occupancy (AOO of $56 \mathrm{~km}^{2}$ ). It grows in primary and secondary montane forests and these forests are under threat of deforestation and habitat destruction. Given that it is only known from eight localities, has a small AOO, and its habitat is threatened, it is assessed here as Vulnerable (B2ab(i,ii,iii)).

Specimens examined. PENINSULAR MALAYSIA: Perak: Gunung Korbu, 22 Jul 1933, Symington KEP 32222 (KEP). Kelantan: Gunung Stong, 10 Oct 1934, Symington KEP 37680 (KEP). Pahang: Central Highlands, 3 Jun 1933, Symington KEP 30968 (KEP); Cameron Highlands, Gunung Beremban, 15 Jan 1979, Cassein 803 (KEP); ibidem, 27 Oct 1972, Chan FRI 16831 (KEP); Gunung Brinchang, 20 Jan 2011, Imin FRI 71942 (KEP); Mt Beremban, 3 Oct 1963, Chew CWL 787 (KEP); Fraser's Hill, 24 Oct 1949, Anonymous 66576 (KEP); ibidem, 10 Jul 1930, Anonymous 22506 (KEP); ibidem, 14 Nov 1937, Symington KEP 45034 (KEP); ibidem, 29 Sep 1922, Burkill \& Holttum 8938 (SING); Gunung Jasar, 9 Sep1970, Whitmore FRI 15470 (KEP); ibidem, 7 Apr 1934, Symington KEP 36126 (KEP). Johor: Kluang, Gunung Blumut, 25 Sep 1970, Mhd Shah \& Sanusi MS 2201 (KEP); ibidem, 23 Sep 1970, Suppiah FRI 17815 (KEP).

Notes. In his treatment of this species, Kochummen (1989: 167) recognised an entity (species 4) from Gunung Blumut as distinct from Litsea acrantha, which was said to have leaves that are only sparsely hairy below and with a rounded base to the blade. After having seen more specimens of Litsea acrantha, I conclude that Kochummen's species 4 falls within the general variation of $L$. acrantha.

In the original description of Litsea acrantha by Ridley (1920: 152), only one gathering without a number is mentioned: Native Collector FMS Museum s.n. The K specimen of this gathering [K000797079] is designated here as the lectotype.

In the original description of Litsea terminalis by Ridley (1925: 330), only one gathering is mentioned: Yapp 494. The K specimen of this gathering [K000797080] is designated here as the lectotype. 
3. Litsea angulata Blume, Bijdr. Fl. Ned. Ind. 11: 563 (1826); Ridley, Fl. Malay Penins. 3: 120 (1924); Kochummen in Ng, Tree Fl. Malaya 4: 152 (1989). - Tetranthera angulata (Blume) Nees, Syst. Laur. 544 (1836). - TYPE: [Indonesia, Java], Salak, November, Blume s.n. (lectotype L [L0036587], designated here).

Tree 12-18 m tall, dbh 38-50 cm. Twigs slender, 3-4 mm thick, angular in crosssection, sparsely hairy when young; terminal leaf bud ovoid, 4.3-5.5 mm long, apex acute to acuminate, velutinous. Leaves alternate; leaf blade leathery, elliptic, ellipticoblong or obovate, 10-20 $\times 4-6 \mathrm{~cm}$, apex acute or acuminate, base cuneate, olive brown when dry; secondary veins 6-9 pairs, arching gradually towards the margin; tertiary veins scalariform-reticulate; surface above shining, glabrous, midrib sunken, secondary veins sunken, tertiary veins obscure; surface below glabrous, midrib and secondary veins raised, tertiary veins obscure; petiole half-terete, 10-25 mm long, slender, glabrous, drying black. Inflorescences clusters of umbels, $0.5-0.7 \mathrm{~cm}$ long, on young twigs below leaves, sparsely hairy; infructescence $3.6-5 \mathrm{~cm}$ long. Flowers unknown. Fruits ellipsoid, 20-25 × 10-12 mm, apex bluntly pointed, shiny, dark red when mature; cupule woody, shallow, 6-7 $\mathrm{mm}$ in diameter, smooth, sparsely hairy, patent, margins entire; stalk slightly swollen, 14-17 × 4-5 mm.

Distribution. Peninsular Malaysia, Sumatra, Borneo and Java (see Fig. 2).

Ecology. Growing in lowland forest at $30 \mathrm{~m}$ altitude. Flowering in July; fruiting in December.

Provisional IUCNconservation assessment. This species is known from many localities, mainly in Borneo, Sumatra and Java, and has a very large extent of occurrence (EOO of 2,770,455 $\mathrm{km}^{2}$ ) and area of occupancy (AOO of $256 \mathrm{~km}^{2}$ ). For these reasons, an assessment of globally Least Concern is proposed.

Specimens examined. PENINSULAR MALAYSIA: Perak: Larut, Dec 1883, King's Collector 5350 (BM, K). Selangor: Gua Batu, Jul 1897, Ridley 8505 (K).

Notes. In the original description of Litsea angulata by Blume (1826: 563), the only data given was that it had been collected in November, from Salak, and that it has the local name Huru Minjak, Huru Pantjan or Huru Merang. Of the six Blume specimens of this species from Salak available for lectotypification [L0036584, L0036585, L0036586, L0036587, L0036588, L0036589], only one [L0036587] mentions the month, locality and one of the local names, and therefore it is designated here as the lectotype.

Only very immature flowers of this species are known. 
4. Litsea artocarpifolia Gamble, Bull. Misc. Inform. Kew 1910: 316 (1910); Ridley, F1. Malay Penins. 3: 116 (1924); Kochummen in Ng, Tree Fl. Malaya 4: 152 (1989). TYPE: [Peninsular Malaysia], Perak, Relan Tujor, June 1888, Wray 2233 (lectotype K [K000797040], designated here; isolectotype BM [BM000799032]).

Tree 6-20 m tall, dbh 15-30 cm, monopodial; bark light brown, smooth, inner bark orange, sapwood white. Twigs stout, 5-10 $\mathrm{mm}$ thick, rounded to angular in crosssection, velutinous; hairs yellowish, curly, erect; terminal leaf bud 13-15 mm, apex acute, velutinous. Leaves alternate; leaf blade coriaceous, oblanceolate, 25-40 × 11-21 $\mathrm{cm}$, apex rounded to slightly emarginate, base attenuate; secondary veins 13-20 pairs, curving near the margin and brochidodromous at the margin; tertiary veins scalariform; surface above glabrous except midrib densely hairy, midrib and secondary veins sunken, tertiary veins distinct; surface below glaucous, densely hairy, midrib and secondary veins raised, tertiary veins distinct; hairs yellowish, curly; petiole channelled, 20-30 $\mathrm{mm}$ long, slender to swollen at base, pubescent. Inflorescences with the appearance of racemes of umbels, 5-8 cm long, axillary on twigs; densely hairy; umbels $0.5-0.6 \mathrm{~cm}$ in diameter; bracts 5, suborbicular, concave, 4-5 × 6-7 mm, velutinous; infructescence with 1-3 fruits. Flowers: male flowers 5 in each umbel, perianth lobes 6, lanceolate to linear, 3.8-4.2 $\times 1-1.2 \mathrm{~mm}$, apex acuminate, hairy outside and inside, stamens 9 or 12, unequal, 2.8-4.4 mm long, sparsely hairy, anthers $1-1.5 \mathrm{~mm}$ long; female flowers unknown. Fruits ellipsoid, 33-50 × 20-30 mm, apex acute, smooth, glabrous; cupule 25-31 × 14-24 mm, woody, warty, covering up to half of fruit, margins entire to lobed, perianth lobes $6.7-8 \times$ c. $4 \mathrm{~mm}$, apex rounded; stalk swollen, 5-10 $\times 3-8 \mathrm{~mm}$.

Distribution. Peninsular Malaysia, Sumatra and Borneo (see Fig. 3).

Ecology. Growing in primary and secondary hill forests. Flowering in June; fruiting from February to June.

Provisional IUCN conservation assessment. This species is known from about 15-20 localities and has a large extent of occurrence (EOO of 1,568,512 $\mathrm{km}^{2}$ ) and area of occupancy (AOO of $80 \mathrm{~km}^{2}$ ). Given this, and the fact that it can grow in secondary vegetation, an assessment of globally Least Concern is proposed.

Specimens examined. PENINSULAR MALAYSIA: Kedah: Bukit Bintang Bingsu, 22 Jan 1939, Yunus FMS 50004 (KEP). Perak: Gunung Bubu, 20 Jun 1967, Selvaraj FRI 11166 (K, KEP); Bubu F.R., 30 Dec 1932, Mhd Taha 29048 (KEP); Plus F.R., 17 Feb 1935, Yassim 39055 (KEP). Kelantan: Sungai Pelatan, 31 Oct 1933, Mohamaat 29111 (KEP). Pahang: Tioman, Gunung Kajang, 28 Apr 2012, Chew T213 5c (KEP). Selangor: Bukit Lagong, Unknown FRI 101 (KEP).

Notes. In the original description of Litsea artocarpifolia by Gamble (1910a: 316), only one gathering is mentioned: Wray 2233. The $\mathrm{K}$ specimen of this gathering [K000797040] is designated here as the lectotype. 


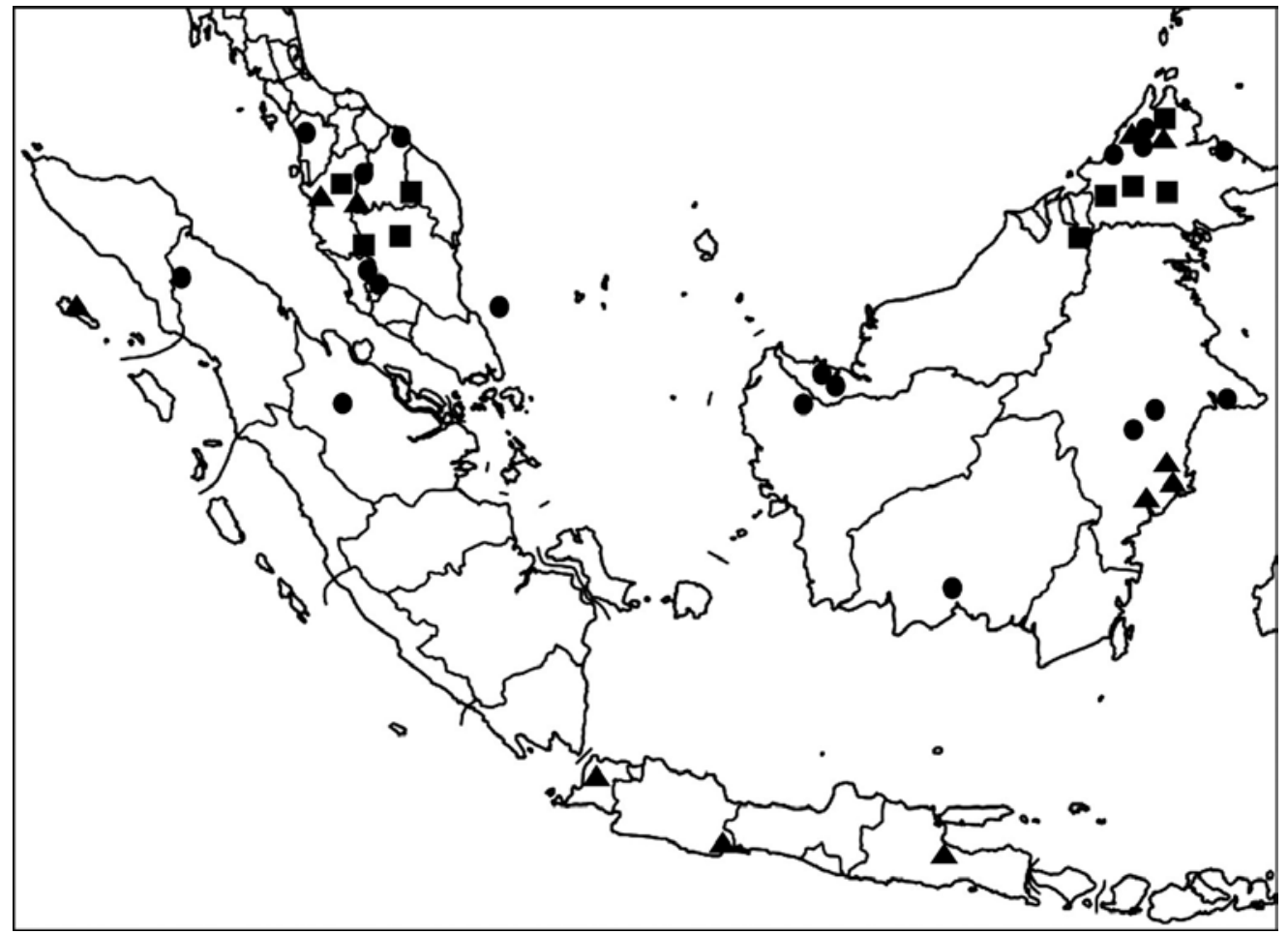

Fig. 3. Distribution of Litsea artocarpifolia $(\bullet)$, L. brachystachya $(\mathbf{\Delta})$ and L. chewii $(\mathbf{\square})$.

5. Litsea brachystachya (Blume) Boerl., Handl. Fl. Ned. Ind. 3: 143 (1900); Ridley, Fl. Malay Penins. 3: 119 (1924); Kochummen in Ng, Tree Fl. Malaya 4: 152 (1989). - Tetranthera brachystachya Blume, Mus. Bot. 1: 384 (1851). - TYPE: [Indonesia], Java, Blume s.n. (lectotype L [L0036630], designated here).

Tree 12-30 m tall, dbh 25-40 cm. Twigs slender, 3-3.7 mm thick, round in crosssection, glabrous; terminal leaf bud linear, 2.4-4.5 mm long, apex acuminate, velutinous; hairs appressed, yellowish. Leaves alternate; leaf blade thinly leathery, elliptic or elliptic-ovate, $10-14 \times 5-7 \mathrm{~cm}$, apex acute to acuminate, base cuneate to almost rounded, sometimes asymmetrical, margins recurved; secondary veins 7-9 pairs, curved towards the margin; tertiary veins scalariform-reticulate; surface above glabrous, glossy rich green, midrib and secondary veins sunken, tertiary veins distinct; surface below glabrous, glaucous, midrib and secondary veins raised, tertiary veins distinct; petiole half-terete, 12-28 $\mathrm{mm}$ long, slender, glabrous. Inflorescences with the appearance of a raceme of umbels, $1.4-4.2 \mathrm{~cm}$ long, in the axils of leaves, glabrous; umbels $0.3-0.5 \mathrm{~cm}$ in diameter; bracts 5, suborbicular, concave, 2.4-2.9 $\times 2-2.2$ $\mathrm{mm}$, glabrous. Flowers pale green; male flowers 5 in each umbel, perianth lobes 6 , lanceolate to linear, 1.7-1.9 ×0.4-0.6 mm, apex acuminate, hairy outside and inside, stamens (bright) yellow, 9, unequal, 1-1.6 mm long, sparsely hairy, anthers $0.5-0.6$ $\mathrm{mm}$ long; female flowers 5 in each umbel, perianth lobes 6 , oblong, $1.4-1.5 \times 0.5-0.7$ 
$\mathrm{mm}$, sparsely hairy outside and inside, ovary ellipsoid, c. $1 \mathrm{~mm}$ in diameter, glabrous, style c. $1 \mathrm{~mm}$ long, stigma minute. Fruits globose, 5.5-8 $\times 4.7-7 \mathrm{~mm}$, apex rounded, smooth, glabrous; cupule shallow, c. $2.3 \mathrm{~mm}$ in diameter, margins entire; stalk tapering distally, up to $1.4 \mathrm{~mm}$ thick.

Distribution. Peninsular Malaysia, Sumatra, Borneo and Java (see Fig. 3).

Ecology. Growing in lowland forests at 250-330 $\mathrm{m}$ altitude (and also montane forest to $1500 \mathrm{~m}$ in Borneo). Flowering from July to November; fruiting from July to August.

Provisional IUCN conservation assessment. This species is known from about 11-12 localities, mainly in Borneo, and has a large extent of occurrence (EOO of 2,316,832 $\mathrm{km}^{2}$ ) and a relatively large area of occupancy $\left(\mathrm{AOO}\right.$ of $\left.68 \mathrm{~km}^{2}\right)$. Because of these factors, an assessment of globally Least Concern is proposed.

Specimens examined. PENINSULAR MALAYSIA: Perak: Larut, Nov 1884, King's Collector 6855 (K [4 sheets]); Relau Tujor, Aug 1888, Wray 2886 (K); Mailung, Jul 1888, Wray 2178 (K [2 sheets]).

Notes. This species superficially resembles Lindera lucida (Blume) Boerl., but differs in having four anther flaps per anther and an infloresence that is more like a long spike than a fascicle. Fruiting data is taken from the Sumatran material.

In the original description of Tetranthera brachystachya (Blume 1851: 384), the only collection data given are that the plant came from Java. Of the four Blume specimens [L0036630, L0036631, L0036632, L0036633] from Java of this species available for lectotypification, [L0036630] is selected as the lectotype.

6. Litsea castanea Hook.f., Fl. Brit. India 5: 171 (1886); Ridley, Fl. Malay Penins. 3: 121 (1924); Corner, Wayside Trees Mal. 1: 384 (1988); Kochummen in Ng, Tree Fl. Malaya 4: 152 (1989); Ngernsaengsaruay et al., Thai Forest Bull., Bot. 39: 81 (2011). - TYPE: [Peninsular Malaysia], Malacca, 10 August 1866, Maingay 1779 [Kew distribution no. 1269] (lectotype K [K000797100], designated by Ngernsaengsaruay et al., Thai Forest Bull., Bot. 39: 81 (2011); isolectotype K [K000797101]). (Fig. 4).

Litsea quercina Gamble, Bull. Misc. Inform. Kew 1910: 318 (1910); Ridley, Fl. Malay Penins. 3: 121 (1924); Kochummen in Ng, Tree Fl. Malaya 4: 152 (1989). TYPE: [Peninsular Malaysia], Perak, Gunung Batu Putih, Wray 1174 (lectotype K [K000797099], designated here).

Tree 6-40 m tall; dbh 10-75 $\mathrm{cm}$; buttresses up to $1 \mathrm{~m}$ high; bark smooth, dark to reddish brown, inner bark cream or yellowish and orange mottled with pungent smell, sapwood (pale) yellow. Twigs slender, 2.5-5.3 mm thick, round in cross-section, smooth to slightly angled, covered with yellowish scales when young, sometimes 

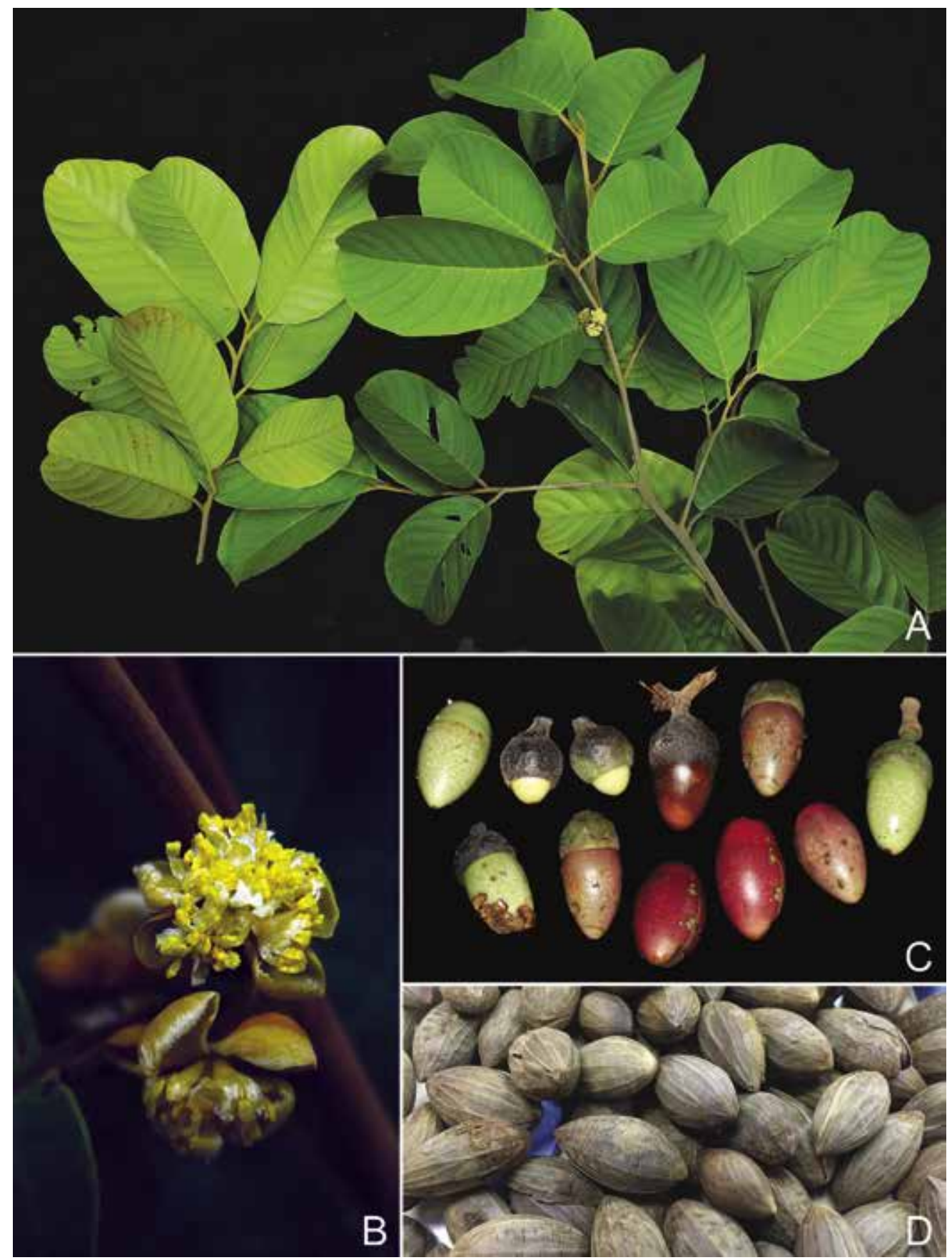

Fig. 4. Litsea castanea Hook.f. A. Leafy branch. B. Flowers. C. Fruits. D. Seeds. From Singapore; A \& B Thomson Road, Seet SING2018-790; C \& D from Lornie Trail. (Photos: A \& B, P.K.F. Leong; C \& D, X.Y. Ng). 
also with a dense layer of short hairs, glabrescent when mature; terminal leaf bud 5-6.5 mm long, covered with yellowish scales, sometimes with a dense layer of short hairs. Leaves alternate; leaf blade coriaceous, ovate to obovate or elliptic, 5-30 $\times$ $2.5-13 \mathrm{~cm}$, apex emarginate or rounded to shortly acute, base rounded to slightly cuneate, sometimes oblique; secondary veins $7-18$ pairs, brochidodromous; tertiary veins scalariform-finely reticulate; surface above glabrous or sparsely covered with yellowish scales on main veins, sometimes with a dense layer of short hairs, deep to dark green, main vein and secondary veins sunken, tertiary veins distinct; surface below glabrous or sparsely covered with yellowish scales on veins, sometimes with a dense layer of short hairs, paler green, midrib and secondary veins raised; petiole $10-30 \mathrm{~mm}$ long, densely to sparsely covered with yellowish scales, sometimes with a dense layer of short hairs. Inflorescences clusters of umbels, 1-2 cm long, along branchlets or in axils of leaves; umbels $1-1.2 \mathrm{~cm}$ in diameter, 4-8 flowers per umbel, densely covered with yellowish scales, sometimes with a dense layer of short hairs; bracts (4-)5, usually imbricate, suborbicular, broadly ovate or ovate, concave, 5-7.5 $\times$ 3-4.5 mm, coriaceous, brown, densely covered with yellowish scales, sometimes with a dense layer of short hairs. Flowers cream to light yellow; male flowers c. 4 in each umbel, perianth lobes 6, linear-oblong or oblong, 2.5-3.5 $\times 0.8-1 \mathrm{~mm}$, sparsely hairy, stamens light yellow, 12-16, unequal, 3-6 mm long, with a few hairs along the filaments, anthers $0.8-1.5 \mathrm{~mm}$ long; female flowers 4 in each umbel, perianth lobes 6 , elliptic to oblong, $1.8-2 \times 0.8-1 \mathrm{~mm}$, sparsely hairy, ovary ellipsoid, $1.8-2 \times$ 0.5-0.8 mm, glabrous, style 1.5-2 mm long, stigma peltate. Fruits ellipsoid, 14-35 × $10-30 \mathrm{~mm}$, glabrous, smooth; cupule woody, 6-10 $\mathrm{mm}$ high, $9-14.5 \mathrm{~mm}$ in diameter, sparsely hairy, margins entire; fruiting pedicels $3.7-10 \times 2.7-3 \mathrm{~mm}$, sparsely hairy; stalk 5-15 mm long, sparsely hairy.

Distribution. Peninsular Thailand, Peninsular Malaysia, Singapore, Sumatra, Borneo and Java (see Fig. 5).

Ecology. Growing in lowland and montane forests, at 0-1400 m altitude. Flowering from June to December; fruiting from August to February.

Vernacular names. Chestnut medang (Singaporean English); Medang telok, Medang bolokar, Medang perawas, Medang kunyit (Malay); Pi-au (Sakai); Durian landak (Temuan).

Provisional IUCN conservation assessment. This species is known from about 40-50 localities and has a large extent of occurrence (EOO of 2,734,393 km²) and area of occupancy (AOO of $172 \mathrm{~km}^{2}$ ). Given this, an assessment of globally Least Concern is proposed.

Specimens examined. PENINSULAR MALAYSIA: Perlis: Mata Ayer F.R., 3 Apr 1957, Whitmore 192 (SING). Kedah: Kedah Peak, Jun 1893, Ridley s.n. (SING). Perak: s.l., 1886, King's Collector s.n. (K, SING); Larut, Oct 1882, King's Collector 3509 (BM, K); Larut, Aug 


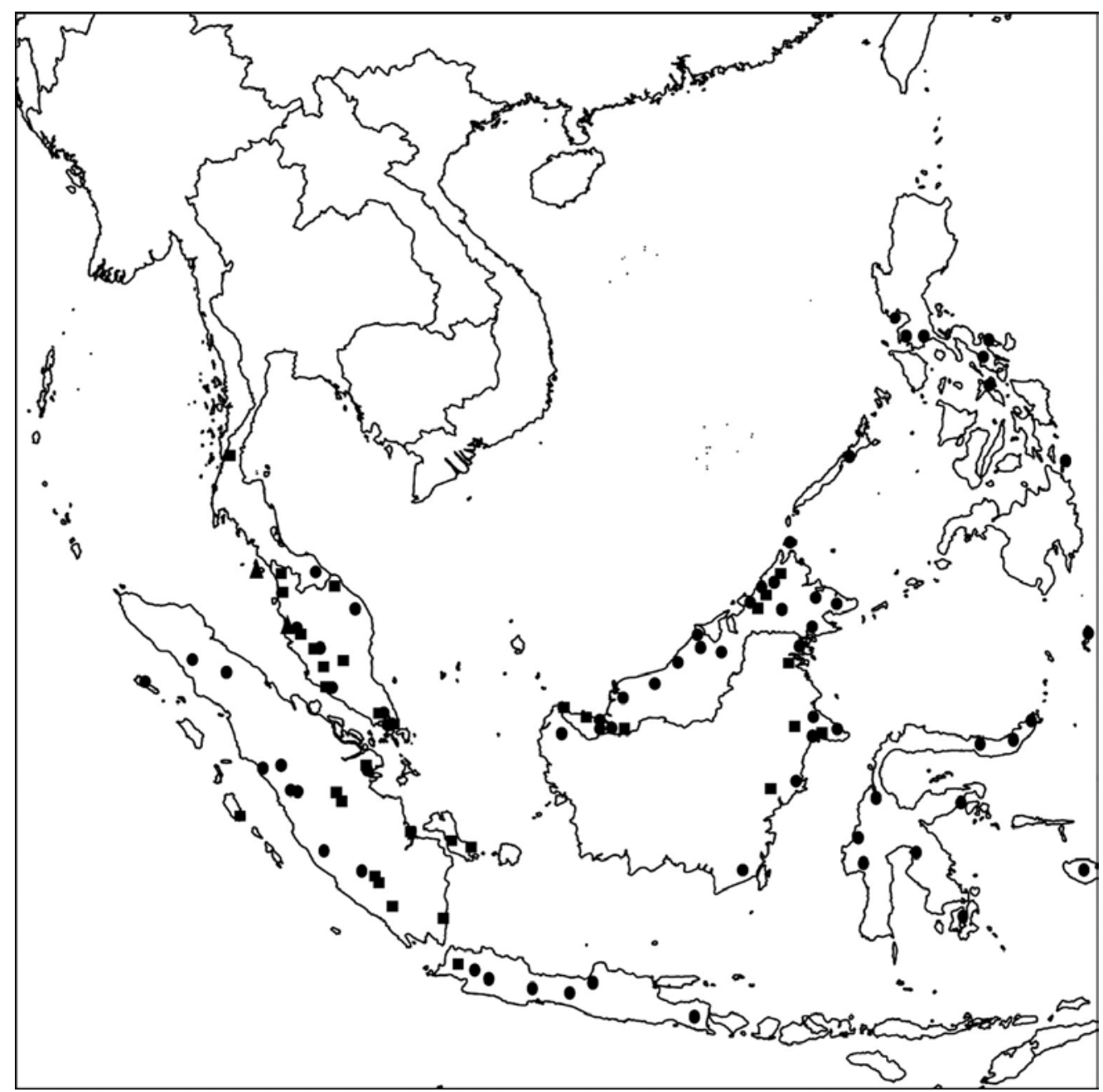

Fig. 5. Distribution of Litsea castanea $(\boldsymbol{\bullet})$, L. claviflora $(\boldsymbol{\Delta})$ and L. cordata $(\bullet)$.

1882, King's Collector 3296 (BM, K [2 sheets]); Larut, Sep 1883, King's Collector 4937 (K [2 sheets], SING [2 sheets]); Larut, Aug 1884, King's Collector 6497 (BM, K, SING); Larut, Jun 1888, Wray 2353 (BM, K); Larut, Aug 1888, Wray 2867 (K, SING [2 sheets]); Kota, Sep 1888, Wray 3119 (K [2 sheets]); Perak F.R., 6 Apr 1935, Symington KEP 39469 (K, KEP); Melintang F.R., 21 Sep 1937, Mhd Ali KEP 34134 (K, KEP). Kelantan: Kota Bahru, 20 Apr 1937, Corner SFN 33407 (SING). Pahang: Kemanusal Reserve, Temelok, 16 Sep 1925, Hamid 10593 (K, KEP, SING); Baloh F.R., 30 Sep 1957, Wyatt-Smith KEP 77970 (K, KEP); Rompin, 23 Oct 1929, Mohamed 17171 (KEP, SING [2 sheets]); Fraser's Hill, 16-30 Sep 1922, Burkill \& Holttum 7884 (SING); Gunung Benom, 15 Mar 1967, Whitmore FRI 3195 (KEP, SING). Selangor: s.l., 1908, Neal $12304 b$ (BM); Klang Gates, 1908 Ridley s.n. (BM); Ulu Bubong, Sep 1886, King's Collector 10926 (K); Ulu Langat, 13 Nov 1960, Gadoh anak Umbai KL 2208 (KEP). Kuala Lumpur: s.1., 1909, Hosking s.n. (K, SING); Mar 1908, Burunoch 13204 (K, KEP, SING); Weld Hill Reserve, 28 May 1920, Forest Department 5030 (SING); ibidem, 24 May 
1917, Curtis's Collector 989 (K, SING [2 sheets]); ibidem, 28 Sep 1920, Haskin 5045 (K, KEP, SING [2 sheets]); ibidem, Forest Department 7862 (SING); ibidem, 5 Jul 1966, Kochummen FRI 2030 (K, KEP, SING); ibidem, 8 Apr 1981, Kochummen FRI 29245 (K, KEP); ibidem, 20 May 1920, Ahmad 5030 (KEP, SING); Public Gardens, 19 Aug 1928, Kassim \& Jaamat 15345 (KEP, SING). Negeri Sembilan: 8 miles along road from Seremban to Kuala Pilah, 5 Nov 1982, Wong FRI 32321 (K, KEP, SING); Kuala Pilah, 2 Mar 1976, Mat Asri FRI 21673 (K, KEP, SING); Pasoh F.R., 19 Jul 1963, Hussain KEP 94054 (SING); Selaru, Forest Department 1870 (SING); Selaru, 22 Apr 1918, Go 1870 (KEP, SING). Malacca: Derry 921 (BM); Berisu, Jun 1892, Ridley 1047 (K, SING [2 sheets]); Bukit Beruang, Sep 1893, Goodenough 1422 (K, SING). Johor: Gunung Blumut, 26 May 1923, Holttum s.n. (SING); ibidem, 23 Sep 1970, Suppiah FRI 17815 (SING); ibidem, 25 Sep 1970, Mhd Shah \& Sanusi MS 2201 (SING); Bukit Badak, Layang, 28 Jan 1959, Hassan \& Kadim H 91 (K, SING); Selaru, 22 Apr 1918, Ludin 1870 (K); Melintang F.R., Kinta, 22 Jun 1964, Kochummen KEP 99921 (K, KEP, SING); Kota Tinggi, Gunung Panti, 6 Jan 2010, Lahiru SING2010-159 (SING).

SINGAPORE: Botanic Gardens, Liane Road [rainforest], 2 Nov 1957, Sinclair 9366 (BM, K, SING); Bukit Timah, 27 May 1953, Sinclair SFN 39650 (K, SING); ibidem, 22 Dec 1970, Noor MN 1492 (SING); ibidem, 15 Dec 1938, Ngadiman SFN 35782 (K, SING [2 sheets]); ibidem, 30 Aug 1938, Henderson SFN 34776 (K, SING [3 sheets]); ibidem, 23 Sep 1938, Ngadiman SFN 35904 (K, SING [3 sheets]); ibidem, 19 Feb 1929, Henderson SFN 36197 (K, SING [2 sheets]); ibidem, 15 Dec 1938, Henderson SFN 35872 (SING); ibidem, 8 Jan 1970, Noor MN 866 (SING); ibidem, Jungle Fall Path, 8 Jan 1970, Noor MN 855 (SING); ibidem, Jungle Fall Path, 16 Jan 1970, Noor MN 874 (SING); ibidem, Jungle Fall Path, 2 Feb 1970, Noor MN 923 (SING); ibidem, Hampstead Path, 22 Dec 1970, Noor MN 1514 (SING); ibidem, Hampstead Path, 22 Dec 1970, Noor MN 1499 (SING); ibidem, Hampstead Path, 22 Dec 1970, Noor MN 1502 (SING); MacRitchie Reservoir, 9 Feb 2010, Gwee SING2010-335 (SING); Thomson Road, 28 Aug 2018, Seet SING2018-790 (SING).

Notes. In the original description of Litsea quercina by Gamble (1910a: 318) only one gathering is mentioned: Wray 1174. The K specimen of this gathering [K000797099] is designated here as the lectotype.

7. Litsea chewii Kosterm., Reinwardtia 6: 287 (1962). - TYPE: [Malyasia], Sabah, Mt Kinabalu, 1 July 1961, Chew et al. 166 (holotype BO n.v.; isotype K [K000815155]).

Litsea helferi Hook.f. var. ovata Gamble, J. Asiat. Soc. Bengal, Pt. 2, Nat. Hist. 75: 168 (1912); Ridley, Fl. Malay Penins. 3: 125 (1924); Kochummen in Ng, Tree Fl. Malaya 4: 158 (1989). - TYPE: [Peninsular Malaysia], Perak, Ulu Batang Padang, Wray 1600 (lectotype K [K000797127], designated here).

Tree or shrub 5-8 m tall, dbh c. $6 \mathrm{~cm}$; bark brownish grey, inner bark pale yellow, sapwood yellow. Twigs slender, 1.6-3 mm thick, round in cross-section, sparsely hairy when young, soon glabrescent; terminal leaf bud ovoid, c. $4.2 \mathrm{~mm}$ long, apex acute to acuminate, densely hairy. Leaves alternate; leaf blade thinly to thickly leathery, elliptic, 4.6-21 × 2-12 cm, apex acute, base cuneate or almost rounded; secondary veins 5-6 pairs, brochidodromous; tertiary veins scalariform-reticulate; surface above 
glabrous, green, midrib and secondary veins sunken, tertiary veins distinct; surface below glabrous, glaucous, midrib and secondary veins raised, tertiary veins distinct; petiole half-terete, 6-15 mm long, slender to swollen, glabrous. Inflorescences clusters of umbels, 0.9-1 cm long, in axils of leaves; umbels $2.3-3.4 \mathrm{~cm}$ in diameter, sparsely hairy; bracts (4-)5, usually imbricate, suborbicular to broadly ovate, concave, 2.5-4.5 $\times 2-3 \mathrm{~mm}$, coriaceous. Flowers white; male flowers c. 6 in each umbel, perianth lobes 6, linear, $1.5-1.7 \times 0.7-1.5 \mathrm{~mm}$, glabrous, stamens 12 , unequal, $0.8-1.3 \mathrm{~mm}$ long, glabrous, anthers 0.6-0.9 mm long; female flowers unknown. Fruits globose, 10-35 × 12-35 mm, apex rounded, smooth, glabrous, pale maroon to red when mature; cupule shallow, 4-4.3 mm in diameter, margins entire, recurved, sparsely hairy; stalk slightly swollen, 2-2.2 $\mathrm{mm}$ thick.

Distribution. Peninsular Malaysia and North Borneo (Sabah and northern Sarawak) (see Fig. 3).

Ecology. Growing in lowland to montane forests at 300-2200 m altitude, sometimes along rivers. Flowering from March to September; fruiting from April to July.

Provisional IUCN conservation assessment. This species is known from at least 12 localities and has a relatively large extent of occurrence (EOO of 281,165 $\mathrm{km}^{2}$ ) and area of occupancy (AOO of $72 \mathrm{~km}^{2}$ ) and therefore an assessment of globally Least Concern is proposed.

Specimens examined. PENINSULAR MALAYSIA: Perak or Pahang: s.1., 8 Sep 1931, Jaamat 28107 (K). Terengganu: Tasik Kenyir, 7 Apr 2009, Kamarul Hisham FRI 67123 (K). Pahang: Cameron Highlands, Gunung Batu Brinchang, 17 Apr 1930, Henderson SFN 23591 (K); Tahan, Teku River, Jul 1911, Ridley 16289 (K).

Notes. In the original description of Litsea helferi var. ovata by Gamble (1912: 168), only one gathering is mentioned: Wray 1600. The $\mathrm{K}$ specimen of this gathering [K000797127] is designated here as the lectotype.

8. Litsea claviflora Gamble, Bull. Misc. Inform. Kew 1910: 363 (1910); Ridley, Fl. Malay Penins. 3: 125 (1924); Kochummen in Ng, Tree Fl. Malaya 4: 154 (1989). - TYPE: [Peninsular Malaysia], Perak, Taiping, February 1886, Kunstler 8492 (lectotype K [K000797070], designated here; isolectotypes BM [BM000799054], K [K000797069 plus specimen with no barcode], P [P00745301]).

Tree 9-15 m tall, dbh 10-15 cm; bark smooth, grey, inner bark pale brown. Twigs slender, 3-4 mm thick, angular to round in cross-section, velutinous; hairs brown, erect; terminal leaf bud lanceolate, 3.8-4.7 $\mathrm{mm}$, apex acute, velutinous. Leaves alternate; leaf blade papery, elliptic-lanceolate, 8.6-13 × 3.3-5.2 cm, apex rounded to broadly acute, base cuneate, sometimes asymmetrical, olive green when dry, 
margins straight; secondary veins 6-8 pairs, curved towards the margin; tertiary veins scalariform-reticulate; surface above glabrous, except densely hairy on midrib, dark green when fresh, midrib sunken, secondary veins sunken, tertiary veins faint; surface below glabrous with hairs on the midrib and secondary veins, midrib and secondary veins raised, tertiary veins distinct; petiole half-terete, 6.6-12 $\mathrm{mm}$ long, slender to slightly swollen at base, glabrous. Inflorescences with the appearance of a raceme of umbels, 11-20 cm long, in the axils of leaves or along branchlets; umbels 0.4$0.5 \mathrm{~cm}$ in diameter; bracts $4-5$, usually imbricate, suborbicular, concave, 3.8-5.7 $\times$ 4.4-6 mm, velutinous, pale waxy green. Flowers: male flowers 6-7 in each umbel, perianth lobes 6 , oblong, $1.8-2.4 \times 0.8-1 \mathrm{~mm}$, hairy outside, glabrous inside, stamens 9-12, yellow, unequal, $1-1.4 \mathrm{~mm}$ long, sparsely hairy, anthers $0.8-1 \mathrm{~mm}$ long; female flowers unknown. Fruits unknown.

Distribution. Endemic to Peninsular Malaysia, where it is recorded from Perak and Kedah (see Fig. 5).

Ecology. Growing in lowland forest, in rich soils, at 150-300 m altitude. Flowering from January and February.

Provisional IUCN conservation assessment. This species is only known from two localities along the west coast of Peninsular Malaysia. Little is known about its ecology. It was first collected in 1886 and then again in 2010. Given the small extent of occurrence and area of occupancy and few known localities, it is assessed here as Endangered (B2ab(ii,iii)).

Specimen examined. PENINSULAR MALAYSIA: Kedah: Sungai Badak, 23 Jan 2010, Teo \& Din KL 5706 (KEP).

Notes. Only one gathering (Kunstler 8492) was cited as type material for the name Litsea claviflora by Gamble (1910b: 363). There are three specimens of this gathering at $\mathrm{K}$, where Gamble worked at the time. All are morphologically very similar, but only two have a card with drawings and dissections typical of specimens worked on by Gamble. Of these, the specimen in K [K000797070] with the most detailed drawing is designated here as the lectotype.

9. Litsea cordata (Jack) Hook.f., Fl. Brit. India 5: 177 (1886); Ridley, Fl. Malay Penins. 3: 118 (1924); Kochummen in Ng, Tree Fl. Malaya 4: 154 (1989); Keng, Concise Fl. Singapore, vol. 1, Gymn. Dicot. 19 (1990); Ng, Gard. Bull. Singapore 57: 226 (2005); Ngernsaengsaruay et al., Thai Forest Bull., Bot. 39: 82 (2011); Chong et al., Nat. Singapore 9: 17 (2016). - Tetranthera cordata Jack, Malayan Misc. 2: 34 (1822); Meisner in DC., Prodr. 15: 196 (1864). - TYPE: [Thailand], Narathiwat, Sirindhorn Peat Swamp Forest, Ngernsaengsaruay \& Chantarasuwan 373 (neotype BKF n.v., designated by Ngernsaengsaruay et al., Thai Forest Bull., Bot. 39: 82 (2011); isoneotype BK n.v.). (Fig. 6). 
Tetranthera cordifolia Meisn. in DC., Prodr. 15: 196 (1864). - Litsea cordifolia (Meisn.) Fern.-Vill. in Blanco, Fl. Filip., ed. 3: 181 (1880). - TYPE: [Peninsular Malaysia], Malacca, 1845, Griffith s.n. [Kew distribution no. 4298] (lectotype K [K000797024], designated here; isolectotypes K [K000797023, K000797025]).

Tree or shrub, 3-36 m tall, dbh 45-60 cm; trunk with short buttresses and in swampy habitats with stilt roots and pneumatophores; bark smooth, greyish brown or (pale) grey, inner bark yellow-brown or brownish, sapwood white to yellowish. Twigs slender, 2.3-4.8 mm thick, round in cross-section, velutinous when young, glabrescent; hairs short, erect, brown; terminal leaf bud ovoid, c. $2.3 \mathrm{~mm}$ long, velutinous. Leaves spirally arranged; leaf blade thinly coriaceous, broadly ovate to oblong, 5.5-26 $\times 4-17 \mathrm{~cm}$, apex obtuse to acute, base deeply cordate to almost rounded, often unequal; secondary veins $6-17$, curving and looping near the margin; tertiary veins scalariform-reticulate; surface above glabrous, except densely hairy on midrib and secondary veins, glossy or bright or dark green with brown or yellowish veins, midrib and main secondary veins sunken, tertiary veins distinct; surface below sparsely hairy, dark green with brown or yellowish veins, glaucous, midrib and secondary veins raised, tertiary veins distinct; petiole 15-35 mm long, velutinous (hairs brown, short, erect). Inflorescences with the appearance of a raceme of umbels, (3-)4.5-20 cm long, terminal or in the axils of leaves or along branchlets; umbels $0.6-1.2 \mathrm{~cm}$ in diameter; bracts (4-)6, usually imbricate, suborbicular, broadly ovate or ovate, concave, 3-7 $\times 3-5 \mathrm{~mm}$, velutinous, pale green. Flowers greenish white; male flowers 6-8(-9) in each umbel, perianth lobes 6, ovate-oblong or ovate-lanceolate, 2-4 × 0.5-1 mm, hairy, stamens 9-12, unequal, 2-4 mm long, sparsely hairy, anthers $0.8-1.2 \mathrm{~mm}$ long; female flowers $6-8$ in each umbel, perianth lobes 6 , ovate-oblong or ovate-lanceolate, $1.5-2.5 \times 0.5-0.8$ $\mathrm{mm}$, hairy, ovary ellipsoid, $1-1.5 \mathrm{~mm}$ in diameter, glabrous, style $1-1.5 \mathrm{~mm}$ long, stigma peltate. Fruits ellipsoid to oblong, 12-25 × 6-10 mm, apex acute, glabrous, blackish purple, black or reddish when mature; cupule shallow or almost flat, 3-5.6 $\mathrm{mm}$ in diameter, margins entire, sparsely hairy; stalk 6-18 $\times 2.5-5 \mathrm{~mm}$, sparsely hairy.

Distribution. Peninsular Thailand, Peninsular Malaysia, Singapore, Sumatra, Borneo, Java, Sulawesi, Moluccas and Philippines (see Fig. 5).

Ecology. Growing in forests and in open vegetation, sometimes along rivers and in (peat) swamp forests, sometimes over limestone, at 0-200 m altitude. Flowering from May to October; fruiting from August to March.

Vernacular names. Heart-shaped medang (Singaporean English); Madang tempong, Madang muitayek (Malay); Madang kehangi (Temuan).

Provisional IUCN conservation assessment. This species is known from many localities and has a very large extent of occurrence (EOO of 5,909,371 km²) and area of occupancy (AOO of $456 \mathrm{~km}^{2}$ ). Because of this, and the fact that it can grow in open vegetation, an assessment of globally Least Concern is proposed. 


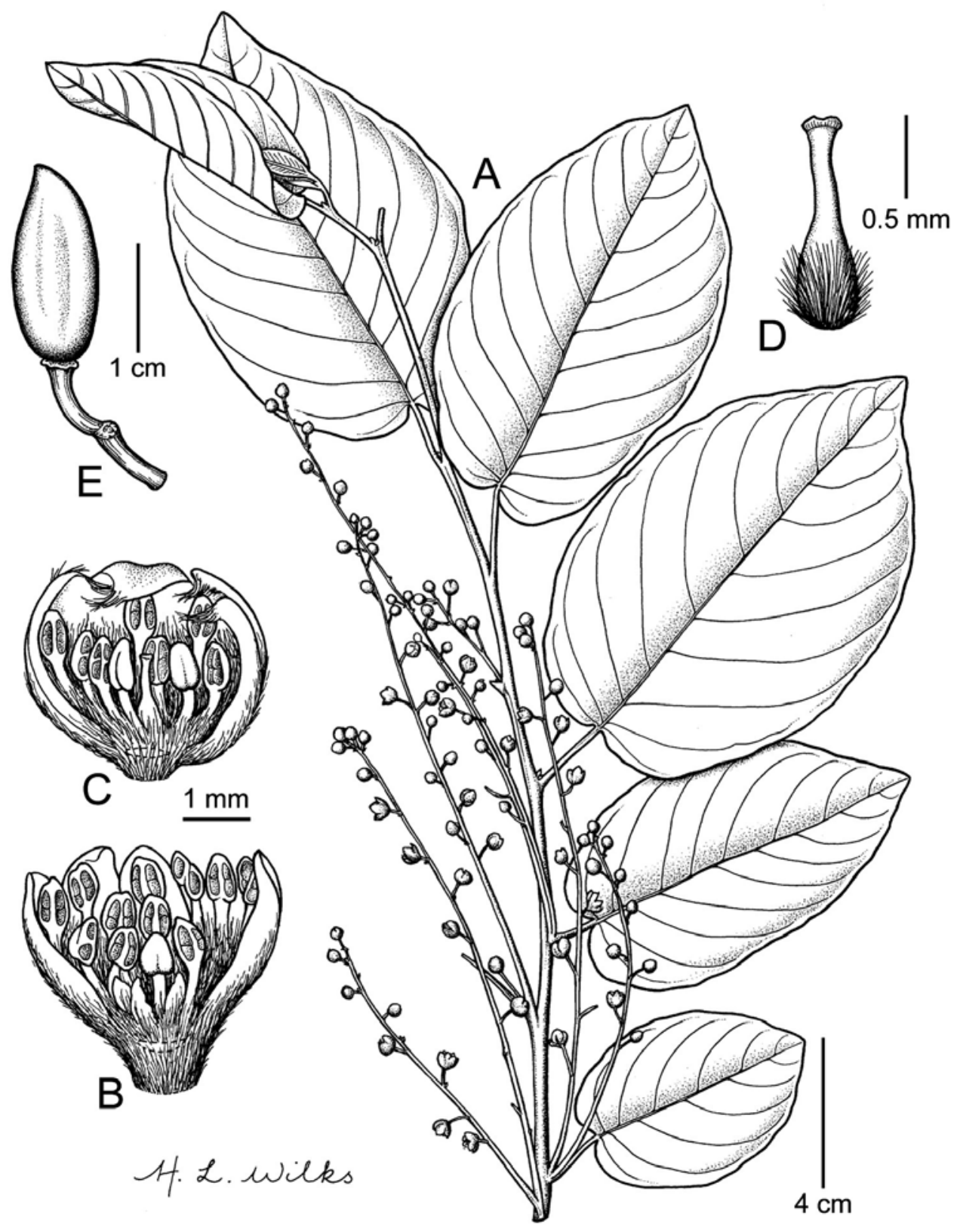

Fig. 6. Litsea cordata (Jack) Hook.f. A. Portion of leafy twig with inflorescences with the appearance of a raceme of umbels. B. Mature opened male flower showing the androecium. C. Mature opened female flower showing the ovary and staminodes. D. Ovary with style and stigma. E. Fruit with stalk. A \& B from Peninsular Malaysia, Taiping, Wray 3045; C \& D from Peninsular Malaysia, Sungai Larut, Wray 2462; E from Peninsular Malaysia, Gua Musang, Kamarudin FRI 31463. Drawn by H. Wilks. 
Specimens examined. PENINSULAR MALAYSIA: Perak: Ipoh, Dec 1895, Curtis 3169 (SING [2 sheets]); ibidem, Sep 1883, King's Collector 8269 (BM); ibidem, Aug 1882, King's Collector 3176 (BM); Larut, Mar 1883, King's Collector 3962 (K, SING [2 sheets]); ibidem, Sep 1884, King's Collector 6529 (K, SING [2 sheets]); ibidem, Nov 1883, Kunstler 5186 (K); ibidem, Scortechini s.n. (K [2 sheets]); Sungai Krian, 10 Oct 1939, Spare 36330 (SING); Kuala Dipang, Sep 1898, Ridley 9597 (K [2 sheets], SING); Taiping, Sep 1888, Wray 3045 (K [2 sheets]); Sungai Larut, Aug 1888, Wray 2871 (K); ibidem, Jul 1888, Wray 2462 (K); ibidem, Jun 1888, Wray 2126 (K); ibidem, Wray 3045 (SING [2 sheets]); Ulu Bera, 1886, King's Collector 10824 (K). Kelantan: Gua Musang, 9 Oct 1990, Kamarudin FRI 31463 (K); Hutan Kusial, 19 Oct 1937, SFO Kelatan 38457 (KEP). Terengganu: Ulu Terengganu, 27 mile Jerangau Road, 22 Sep 1955, Sinclair \& Kiah SFN 40927 (K, SING). Selangor: Kerling, 10 Oct 1899, Goodenough 10537 (SING); Kuala Kepong, Sep 1885, Kunstler 8269 (K); Ulu Langat, 22 Sep 1959, Gadoh anak Umbai KL 1793 (K [2 sheets], SING); Klang River, 29 Jun 1937, Symington KEP 43733 (K, SING); Kerling, 1894, Ridley 10537 (K). Negeri Sembilan: Bukit Tangga, 1 Dec 1923, Nur SFN 11840 (BM, K, SING); Taupie, Aug 1915, Nur s.n. (K, SING). Malacca: s.l., Griffith s.n. (BM); Sungai Uday, Aug 1893, Goodenough 1353 (SING). Johor: Mersing, 23 May 1925, Rauger \& Rahim 5931 (K, SING); Bukit Murdon, Bata Pakat, 9 Nov 1892, Ridley 4027 (K, SING); Kota Tinggi, Dec 1892, Ridley 4226 (SING).

SINGAPORE: s.l., Ridley s.n. (BM); Bukit Timah, Aug 1880, King's Collector 353 (K [2 sheets]); Kranji, Apr 1895, Mat 4743 (SING); Western Catchment, 27 Apr 2004, Samsuri et al. WC 57 (SING); Nee Soon Swamp Forest, 8 Jul 2003, Samsuri et al. NES 86 (SING).

Notes. Only one gathering was cited as type material for the name Tetranthera cordifolia by Meisner (1864): Griffith s.n. [Kew distribution no. 4298] from Malacca. Three sheets of this gathering are present at K and the specimen [K000797024] is designated here as the lectotype.

10. Litsea costalis (Nees) Kosterm., Reinwardtia 7: 501 (1969); Kochummen in Ng, Tree Fl. Malaya 4: 154 (1989); Keng, Concise Fl. Singapore, vol. 1, Gymn. Dicot. 19 (1990); Ng, Gard. Bull. Singapore 57: 226 (2005). - Alseodaphne costalis Nees in Wallich, Pl. Asiat. Rar. 2: 72 (1831); Ridley, Fl. Malay Penins. 3: 100 (1924). - TYPE: Singapore, 1822, Wallich s.n. [EIC 2594B] (lectotype K [K000797144], designated here; isolectotypes BM [BM000799072], K-W [K001116521]). (Fig. 7).

Litsea megacarpa Gamble, Bull. Misc. Inform. Kew 1910: 364 (1910); Ridley, Fl. Malay Penins. 3: 127 (1924); Corner, Wayside Trees Mal. 347 (1940); Keng, Concise Fl. Singapore, vol. 1, Gymn. Dicot. 19 (1990). - TYPE: [Singapore], Toas [Tuas], 1894, Ridley 6456 (lectotype K [no barcode], designated by De Kok, Gard. Bull. Singapore 69: 175 (2017); isolectotypes BM [no barcode], SING [SING0013205]).

Litsea nidularis Gamble, Bull. Misc. Inform. Kew 1910: 365 (1910); Ridley, Fl. Malay Penins. 3: 127 (1924); Ng, Gard. Bull. Singapore 57: 226 (2005). - Litsea costalis (Nees) Kosterm. var. nidularis (Gamble) Ng, Gard. Bull. Singapore 57: 226 (2005). - TYPE: [Peninsular Malaysia], Perak, Larut, 15 November 1884, King's Collector 6883 (lectotype K [K000815138], designated by Ng, Gard. Bull. Singapore 57: 226 (2005); isolectotypes BM, E [E00393260], P [P00745243], SING [SING0229218]). 

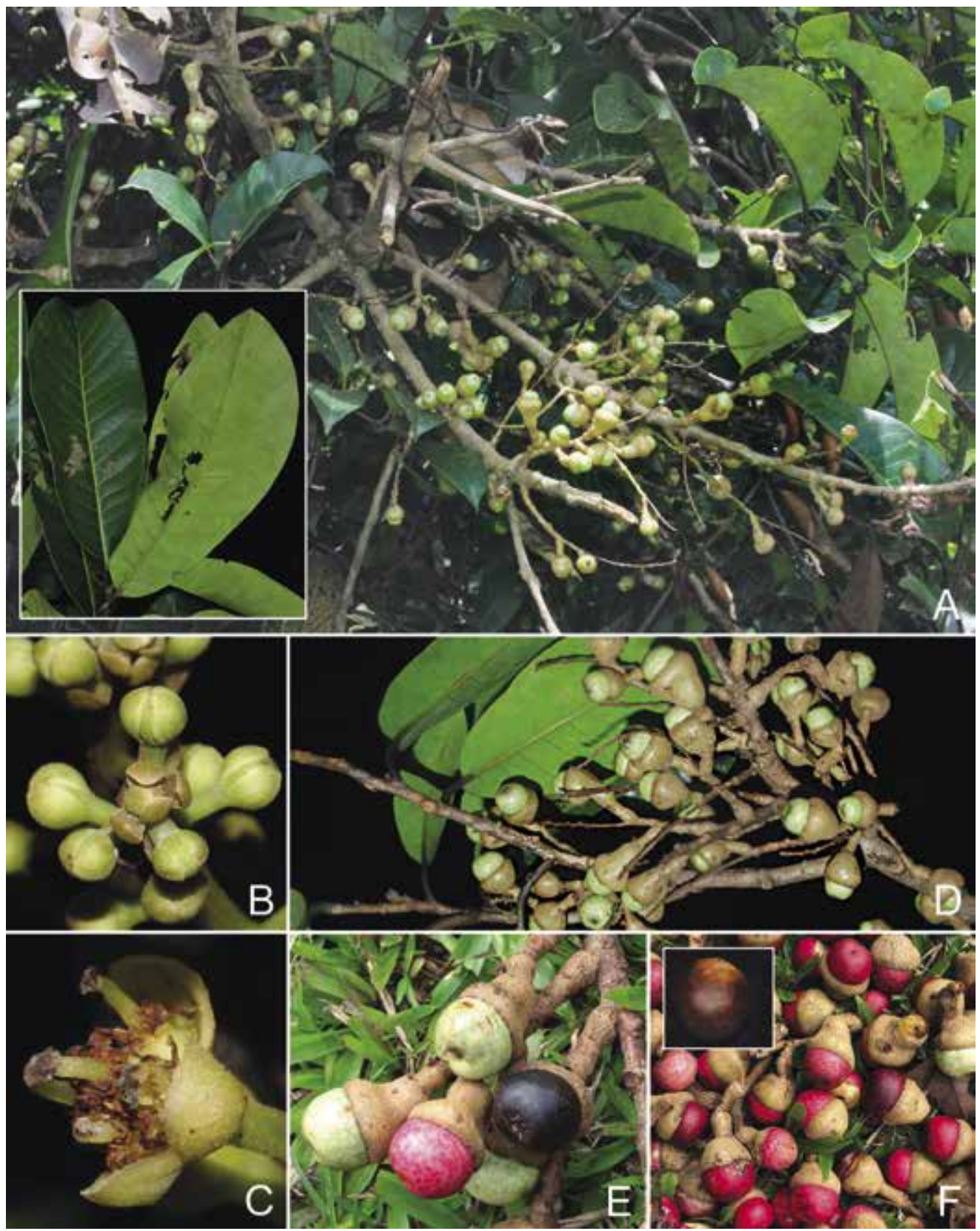

Fig. 7. Litsea costalis (Nees) Kosterm. A. Habit. Inset: Leaves. B. Flower buds. C. Flower showing anthers and stigma. D. Branch with young fruits. E. Fruits in different stages of maturity. F. Fallen fruits. Inset: Seed. From Singapore, Nee Soon Swamp Forest; A inset from Leong et al. SING2011-374; D from Ng et al. SING2017-771. (Photos: A-F, X.Y. Ng; A inset, P.K.F. Leong). 
Tree 5-30 m tall; dbh 15-60 cm; trunk rarely with stilt roots, white sap present; bark light brown or grey to reddish brown, smooth, inner bark pale yellow to yellowish brown or pale orange, slightly mottled, with a strongly fragrant smell, sapwood yellowish. Twigs stout, 4.3-13 mm thick, rounded to strongly angled in cross-section, sparsely hairy when young, soon glabrescent; terminal leaf bud 5-10 mm long, apex acute, velutinous. Leaves alternate, young leaves purple or red, fragrant when crushed; leaf blade leathery, obovate to oblanceolate, 10-47 $\times 4.5-20 \mathrm{~cm}$, apex acute with a short point, base cuneate to attenuate; secondary veins 12-16 pairs, arching near the margin; tertiary veins scalariform-reticulate; surface above glabrous, deep green, glossy, midrib sunken, secondary veins sunken to raised, tertiary venation faint to distinct; surface below glabrous, sometimes glaucous, midrib and secondary veins raised, tertiary venation distinct; petiole half-terete to channelled, 17-70 mm long, slender, glabrous. Inflorescences resembling a raceme, $0.3-1.5 \mathrm{~cm}$ long, sparsely hairy to glabrous, borne in axils of leaves along branchlets or terminal; umbels 5-6 mm in diameter, velutinous; bracts 4-5, decussate, suborbicular or broadly ovate, concave, 2.4-6 × 1.2-4 mm, sparsely hairy outside, glabrous inside. Flowers yellowish white; male flowers 5-6 in each umbel, perianth lobes 6 , oblanceolate, $2.5-3 \times 0.8-1 \mathrm{~mm}$, hairy, stamens 9-12, unequal, 3-5 mm long, glabrous, anthers 0.8-1 mm long; female flowers 5 in each umbel, perianth lobes 6, oblanceolate, 1-1.3 $\times 0.5-1 \mathrm{~mm}$, hairy, ovary globose, c. $0.5 \mathrm{~mm}$ in diameter, glabrous, style $1.5-2 \mathrm{~mm}$ long, stigma peltate. Fruits globose to ellipsoid, $8-30 \times 10-26 \mathrm{~mm}$ in diameter, apex round, glabrous, smooth, reddish when mature; cupule shallow when mature, 14-28 $\mathrm{mm}$ in diameter, 6-10 mm high, margins entire, glabrous, fleshy, patent and only covering the base of the fruit, green; stalk 4.8-11 mm long, 5.5-8.8 mm thick, smelling strongly of resin.

Distribution. Peninsular Malaysia, Singapore, Sumatra and Borneo (see Fig. 8).

Ecology. Growing in primary and secondary forests, at 30-1250 m altitude. Flowering from May to November; fruiting from July to January.

Vernacular names. Ribbed medang (Singaporean English); Medang Lempong, Medang pisang, Medang serai puteh, Medang kuning, Medang tandok, Medang Kaladi (Malay).

Provisional IUCN conservation assessment. This species is known from about 15-20 localities and has a large extent of occurrence (EOO of 1,592,667 $\mathrm{km}^{2}$ ) and a relatively small area of occupancy (AOO of $92 \mathrm{~km}^{2}$ ). Given these factors and its ability to grow in secondary vegetation, an assessment of globally Least Concern is proposed.

Specimens examined. PENINSULAR MALAYSIA: Kedah: Tualang, 1 Jun 1950, Hamzah KEP 63262 (K, KEP). Penang: Province Wellesley, Jul 1890, Curtis s.n. (BM); ibidem, Nov 1890, Curtis s.n. (SING); ibidem, Nov 1890, Curtis 2511 (K, SING [2 sheets]); Government Hill, Apr 1897, Curtis 3279 (K). Perak: Jun 1888, Wray 2337 (SING [2 sheets]); Selama, 22 Aug 1924, Salleh 8804 (KEP); Larut, Aug 1888, Wray 2730 (K); ibidem, Dec 1883, 


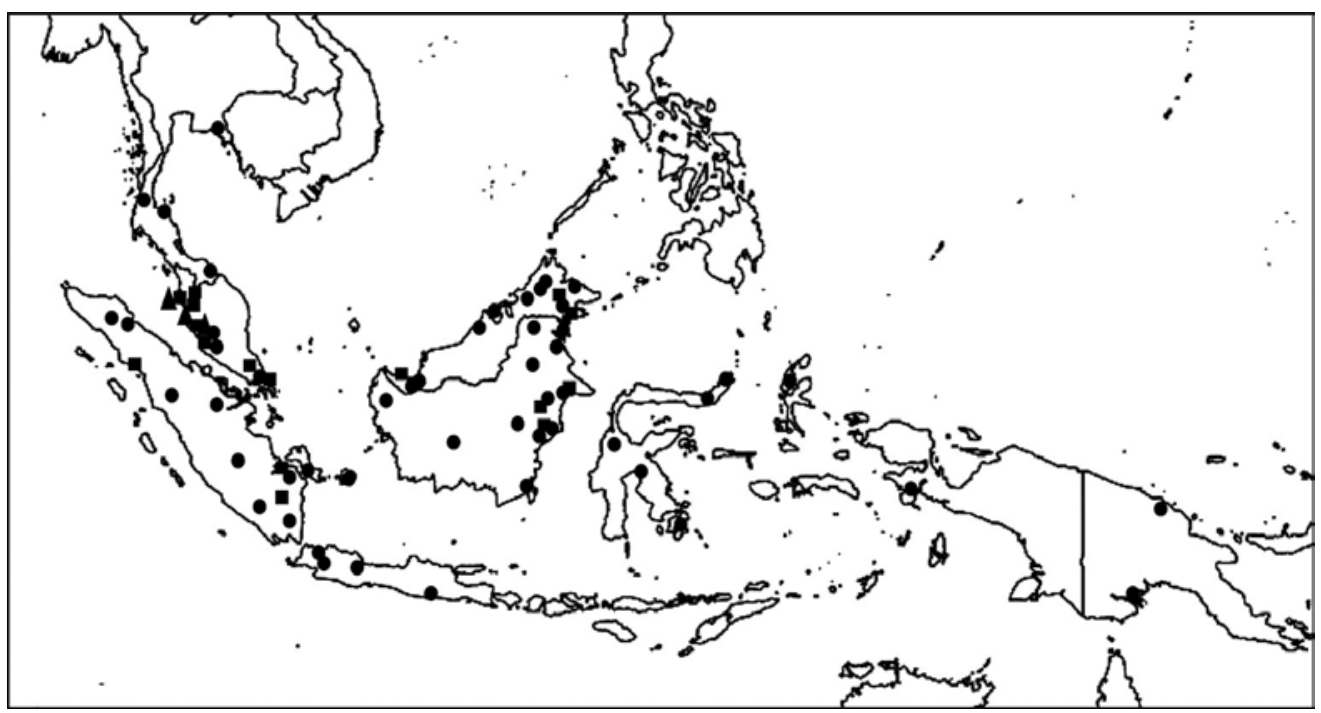

Fig. 8. Distribution of Litsea costalis $(\boldsymbol{\bullet})$, L. curtisii $(\boldsymbol{\Delta})$ and L. elliptica $(\bullet)$.

King's Collector 3697 (K); ibidem, May 1884, King's Collector 6124 (BM, SING); ibidem, Sep 1884, King's Collector 6567 (SING [2 sheets]); ibidem, Sep 1884, King's Collector 6613 (BM, K [2 sheets]); ibidem, Nov 1884, King's Collector 6866 (K, SING); ibidem, Oct 1884, King's Collector 6689 (BM, K [3 sheets]); Larut, Goping, May 1884, King's Collector 6076 (K); ibidem, May 1884, King's Collector 6155 (BM, K [2 sheets]); ibidem, Jun 1884, King's Collector 6237 (SING [2 sheets]); ibidem, Jul 1884, King's Collector 6409 (SING); ibidem, Aug 1884, King's Collector 6443 (BM, K); Larut, Taiping, Oct 1884, King's Collector 6774 (K [2 sheets]); Larut, Kieta, Jan 1885, King's Collector 7204 (BM, K); Grik, 3 Nov 1961, Young KEP 94654 (K, KEP); Babu F.R., 30 Dec 1932, Mhd Paha 29047 (KEP, SING); Serigala, 26 Jan 1930, Ahmad 14360 (KEP, SING); Pondok Tanjung, 30 Aug 1925, Strugnell 9659 (KEP, SING); ibidem, 12 Aug 1934, Symington KEP 37881 (K, KEP). Terengganu: Ulu Dungun near Sungai Bebir, 6 Jul 1968, Wong FRI 9547 (K). Pahang: Gunung Tapis, 29 Sep 1971, Chan FRI 19888 (K, KEP, SING); Chikus F.R., 2 Apr 1952, Saari KEP 51567 (K, KEP). Selangor: Ulu Gombak, 25 Oct 1937, Nur SFN 34228 (BM, K, SING); Ulu Selangor, 10 May 1932, Raman KEP 24880 (K, KEP); Bukit Cherakah F.R., 25 May 1932, Somerville KEP 29209 (K, KEP); ibidem, 14 Apr 1932, Watson 24260 (KEP); ibidem, 13 Apr 1923, Ki-Ai FMS 8280 (KEP, SING); Kelambu F.R., 28 Jul 1919, Hamin 4755 (K, KEP, SING); Rantau Panjang, 4 Jun 1921, Hume 7583 (SING); ibidem, 30 Apr 1907, Hamid 7973 (KEP [2 sheets], SING); Klang Gates, 1909, Burkill 277 (SING); Dusum Tua, May 1896, Ridley 7621 (K, SING). Kuala Lumpur: Weld Hill, 3 Jun 1917, Hamid 2914 (KEP); ibidem, 5 May 1920, Ahmad 5115 (KEP); ibidem, 30 Apr 1918, Hamid 251 (KEP); Kuala Lumpur, Public Gardens, May 1902, Curtis 3770 (K, SING [3 sheets]). Negeri Sembilan: Tampin, Nov 1932, Corner s.n. (SING). Johor: Bandar Tenggara, Linggiu, 23 Jul 1991, Lesmy FRI 35922 (K, KEP, SING); 7th mile Kota TinggiMawai Road, 4 Feb 1935, Corner SFN 28715 (K, KEP); Kuantan, 16 Nov 1921, Mohammed 6658 (SING).

SINGAPORE: s.l., 1930, Corner s.n. (K); Reservoir Jungle, 21 Dec 1930, Corner s.n. (SING); Reservoir Jungle, 8 Jan 1937, Corner s.n. (SING); Nee Soon Firing Range, 11 Sep 2011, Leong et al. SING2011-374 (SING); edge of 2nd range at Nee Soon, 5 Apr 1992, Turner et al. 128 (SING); Nee Soon Swamp Forest, forest edge of range 2, 15 Dec 2017, Ng et al. SING2017- 
771 (SING); Bukit Timah, Hampstead Path, 22 Dec 1970, Noor MN 1512 (SING); Kamang, 15 Nov 2006, Teo \& Din KL 5325 (KEP); Kuala Lipis, 25 May 2006, Teo \& Din KL 5247 (KEP).

Notes. When the flowers were boiled for dissection, they produced a copious amount of a gelatinous material which was not found when flowers of other species were boiled.

Corner (1940: 348) reported that this species has a slight amount of white latex which discolours quickly to yellow when exposed to air.

According to $\mathrm{Ng}$ (2005), Litsea costalis var. nidularis differs from the typical variety in having smaller and narrower leaves and less prominent venation. However, he also said that intermediates between these two forms occur, and at least one specimen from Brunei (Dransfield ID 7249) has leaves of both types. I found no clear difference between these two varieties in the material from Peninsular Malaysia and do not recognise the infraspecific taxa.

Only one gathering was cited as type material for the name Alseodaphne costalis by Nees von Esenbeck in Wallich (1831: 72): Wallich s.n. [EIC 2594B] from Singapore. Three sheets of this gathering are known and the K specimen [K000797144] is designated here as the lectotype.

11. Litsea curtisii Gamble, Bull. Misc. Inform. Kew 1910: 363 (1910); Ridley, F1. Malay Penins. 3: 127 (1924); Kochummen in Ng, Tree Fl. Malaya 4: 155 (1989). - TYPE: [Peninsular Malaysia], Perak, Larut, May 1884, King's Collector 6161 (lectotype K [K000815141], designated here; isolectotypes BM [BM000799080], K [no barcode], P [P00745268]).

Tree 7-36 m tall; dbh 30-80 cm; bark smooth, flaking in places to leave large scroll marks, fawn or pale pink, inner bark light yellow-brown rapidly darkening to light redbrown, with an aromatic smell, sapwood greenish white. Twigs slender, 2.8-3.3 mm thick, rounded to angled in cross section, glabrous; terminal leaf bud 8-10 mm long, apex acute, velutinous. Leaves alternate; leaf blade thinly leathery, elliptic to obovate, $7-30 \times 2.3-12.5 \mathrm{~cm}$, apex acute to acuminate, base cuneate to attenuate; secondary veins 10-15 pairs, arching and brochidodromous near the margin; tertiary venation scalariform; surface above glabrous, midrib and secondary veins sunken, tertiary venation indistinct; surface below glabrous, slightly glaucous, midrib and secondary veins raised, tertiary venation indistinct; petiole $15-37 \mathrm{~mm}$ long, half-terete, glabrous. Inflorescences clusters of umbels, $15-20 \mathrm{~cm}$ long, along branchlets or in axils of leaves, sparsely hairy when young, glabrescent; hairs light brown, appressed; bracts 4 , suborbicular, concave, $4.3-4.8 \times 3.1-4.2 \mathrm{~mm}$, sparsely hairy outside, glabrous inside; infructescence with 1-3 fruits. Flowers: male flowers 5-8 in each umbel, perianth lobes 6 , oblong, apex acute to rounded, 1.5-2.3 $\times 0.5-0.9 \mathrm{~mm}$, glabrous, stamens 6 , unequal, 2.4-3.7 mm long, sparsely hairy, anthers $0.9-1.3 \mathrm{~mm}$ long; female flowers unknown. Fruits globose to ellipsoid, 9-10 × 5-6.7 mm, apex rounded, smooth, glabrous; cupule shallow, $8-9 \mathrm{~mm}$ in diameter, margins entire; stalk 7-10 $\times 1.8-2$ $\mathrm{mm}$, swollen. 
Distribution. Endemic to Peninsular Malaysia, where it is recorded from Penang and Perak (see Fig. 8).

Ecology. Growing in lowland and hill forests, at 360-480 m altitude. Flowering from May to June; fruiting in August.

Vernacular name. Medang telor.

Provisional IUCN conservation assessment. This species is known from only four localities and no new collections have been made since 1934. There are threats of deforestation and habitat destruction to the known locations and given these threats and its restricted range (extent of occurrence is $1936 \mathrm{~km}^{2}$ ), it is assessed here as Endangered (B1ab(i,ii,iii)).

Specimens examined. PENINSULAR MALAYSIA: Penang: Goverment Hill, Cooly lines, Jun 1890, Curtis 2449 (BM, K, KEP). Perak: s.l., Scortechini 162 (K); Taiping, 21 Aug 1916, Burkill SFN 2178 (KEP); Ijok F.R., 10 Aug 1934, Symington KEP 37391 (KEP).

Notes. Three gatherings were cited as type material for the name Litsea curtisii by Gamble (1910b: 363): Curtis 2449, King's Collector 6161 and Scortechini 162. These gatherings are duplicated in several herbaria. The specimen in K [K000815141] of King's Collector 6161 is designated here as the lectotype as it has numerous flowers and a card with the characteristic drawings and dissection made by Gamble.

12. Litsea elliptica Blume, Bijdr. Fl. Ned. Ind. 11: 563 (1826); Kochummen in Ng, Tree Fl. Malaya 4: 155 (1989); Keng, Concise Fl. Singapore, vol. 1, Gymn. Dicot. 19 (1990). - Tetranthera elliptica (Blume) Nees, Syst. Laur. 550 (1836); Meisner in DC., Prodr. 15: 188 (1864); Ng, Gard. Bull. Singapore 57: 230 (2005); Ngernsaengsaruay et al., Thai Forest Bull., Bot. 39: 51 (2011). - TYPE: [Indonesia], Java, Mt Salak, Unknown s.n. (lectotype L [L0036670], designated here; isolectotypes BO [sheet no. BO-1274910], U [U0002803]). (Fig. 9).

Litsea petiolata Hook.f., Fl. Brit. India 5: 171 (1886); Ridley, J. Straits Branch Roy. Asiat. Soc. 33: 132 (1900); Ridley, Fl. Malay Penins. 3: 119 (1924); Keng, Concise Fl. Singapore, vol. 1, Gymn. Dicot. 19 (1990). - TYPE: [Peninsular Malaysia], Malacca, 1865, Maingay 1998 [Kew distribution no. 1265] (lectotype K [K000797128], designated here).

Litsea scortechinii Gamble, Bull. Misc. Inform. Kew 1910: 362 (1910); Ridley, Fl. Malay Penins. 3: 124 (1924); Kochummen in Ng, Tree Fl. Malaya 4: 164 (1989). - TYPE: [Peninsular Malaysia], Perak, Haram Parak, June 1884, Scortechini 866 (lectotype K [K000797077], designated here; isolectotypes K [no barcode], SING [SING0055943]). 

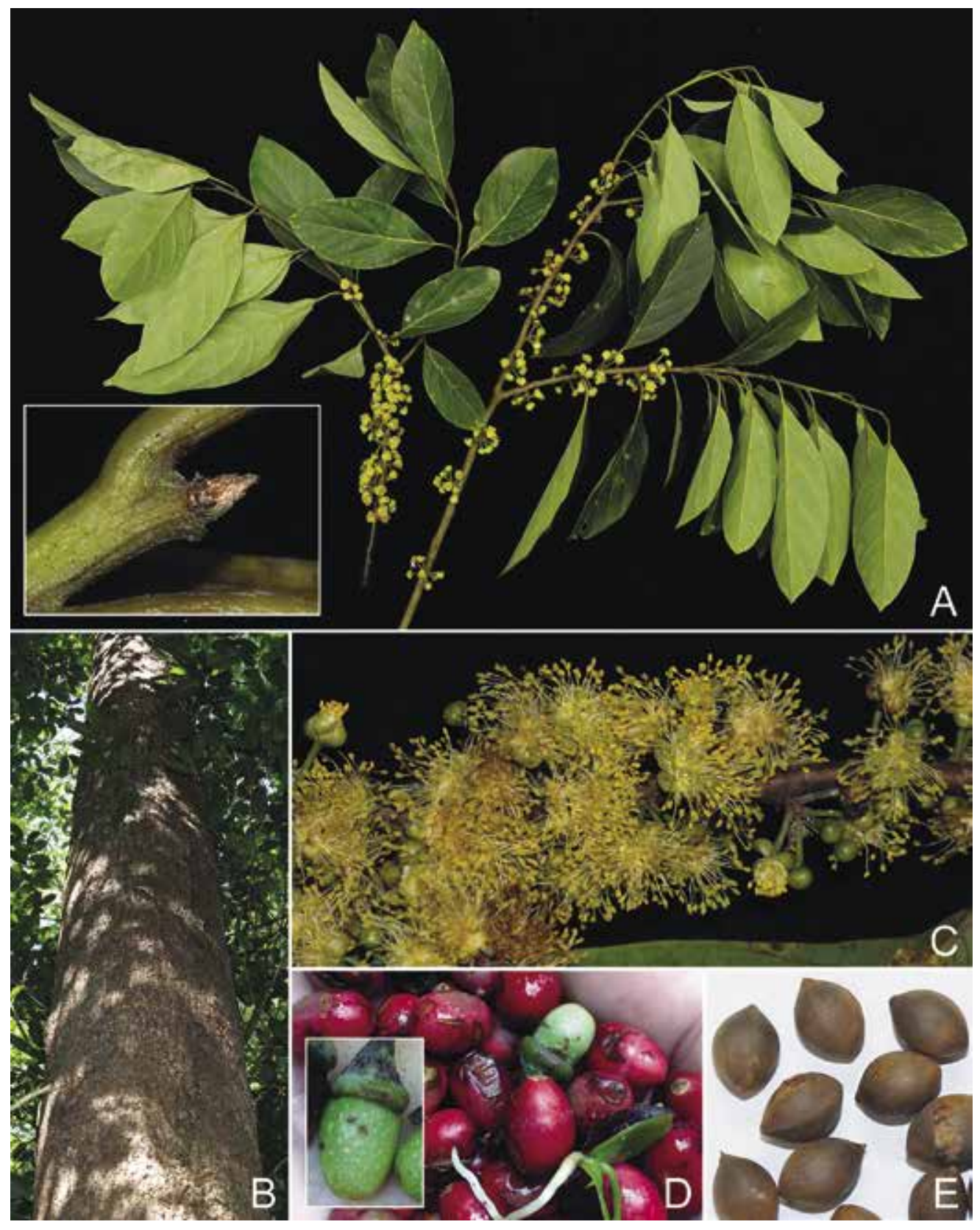

Fig. 9. Litsea elliptica Blume A. Leafy branch with flowers. Inset: Terminal leaf bud. B. Tree trunk. C. Flowers showing numerous anthers. D. Fallen fruits. Inset: Unripe fruit with cupule. E. Seeds. From Singapore; A from Admiralty Forest, Lua SING2014-106; B from Chestnut Peninsula, Lim SING2020-436; A inset, C-E from Pasir Panjang Nursery. (Photos: A, P.K.F. Leong; B, R.C.J. Lim; A inset, C-E, X.Y. Ng). 
Tree 4.5-45 m tall; dbh 20-80 cm; trunk with short buttresses, up to $1 \mathrm{~m}$ high; bark smooth, rarely fissured or scaly, lenticellate, greyish brown or grey, inner bark pinkish with a strong spicy smell, sapwood pale yellow. Twigs slender to stout, 1.7-7.7 mm thick, rounded in cross-section, glabrous, sometimes with patches of hairs; terminal leaf bud ovoid, 3.8-5.1 mm long, apex acuminate, velutinous; hairs long, appressed, yellowish. Leaves alternate; leaf blade thinly coriaceous, pungent when crushed, elliptic to lanceolate, $6-20 \times 2-7.8 \mathrm{~cm}$, apex acute to rounded or acuminate, base cuneate, sometimes oblique; secondary veins 4-10 pairs, curving near the margin, yellow; tertiary veins scalariform-reticulate; surface above glabrous except for a few hairs on midrib, dark green, midrib sunken, secondary veins sunken to flattened, tertiary veins distinct; surface below glabrous or sometimes sparsely hairy on veins, glaucous, grey-green, midrib and secondary veins raised, veins sometimes reddish, tertiary veins distinct; petiole half-terete, 7-32 mm long, slender, glabrous or sometimes with some hairs on upper surface. Inflorescences clusters of umbels, 1-3 cm long, arranged along branchlets, in axils of leaves or arising from bare twigs, glabrous, umbels $2.7-10 \mathrm{~mm}$ in diameter, light green; bracts 4-5, decussate, suborbicular or broadly ovate, concave, 2.5-5.5 × 1.9-4 mm, glabrous to sparsely pubescent outside, glabrous inside, pale green. Flowers white; male flowers 5-6 in each umbel, perianth lobes 6, obovate to lanceolate, 1.8-4 × 0.9-1.5 mm, apex acute, sparsely hairy, stamens 9-12, unequal, 2-7 mm long, sparsely hairy, yellow, anthers 1-2 mm long; female flowers 5-6 in each umbel, perianth lobes 6 , obovate-oblong, 2.5-3 × 1-1.5 mm, hairy, ovary globose, c. $1 \mathrm{~mm}$ in diameter, glabrous, style $2-2.5 \mathrm{~mm}$ long, stigma peltate. Fruits globose to ellipsoid, 7-11 × 6-7 mm, apex acute, smooth, glabrous, dark pink to purple or black when mature; cupule 2.6-5 $\mathrm{mm}$ in diameter, $0-2 \mathrm{~mm}$ high, margins entire, patent to covering only the base, smooth, glabrous; fruiting pedicels 5-7 $\mathrm{mm}$ long, glabrous; stalk 5-8 mm long, slightly swollen, $1.2-1.5 \mathrm{~mm}$ thick, glabrous.

Distribution. Thailand, Peninsular Malaysia, Singapore, Sumatra, Borneo, Java, Sulawesi, Moluccas and New Guinea (see Fig. 8).

Ecology. Growing in primary and secondary lowland forests, rarer in hill or montane forests, at 0-600 $\mathrm{m}$ altitude. Flowering throughout the year; fruiting from December to May.

Vernacular names. Common medang, Perawas (Singapore).

Uses. Ridley (1924: 119) reported that it is highly valued in local medicines.

Provisional IUCN conservation assessment. This species is known from numerous localities and has a very large extent of occurrence (EOO of 7,122,536 $\mathrm{km}^{2}$ ) and area of occupancy (AOO of $400 \mathrm{~km}^{2}$ ). Given this wide distribution, the number of known localities, and the fact that it can grow in secondary vegetation, an assessment of globally Least Concern is proposed. 
Specimens examined. PENINSULAR MALAYSIA: Perak: s.l., Jul 1883, King's Collector 7761 (BM). Kelantan: Sungai Jenat, 28 Jan 1935, SFO Kelantan 33355 (KEP). Selangor: Fraser's Hill, 16-30 Sep 1922, Burkill \& Holttum 7857 (KEP); Weld Hill, 10 Dec 1925, Hamid 10938 (KEP); Bukit Lagong, 6 Mar 1969, Suppiah KEP 108883 (KEP); Lagong F.R., 2 Dec 1961, Kochummen KEP 94384 (KEP). Johor: Keluang, 20 Nov 1990, Remy KL 3970 (KEP). SINGAPORE: s.l., Cantley's Collector s.n. (SING [3 sheets]); s.l., Cantley's Collector 2977 (SING); Gardens' Jungle, 1890, Ridley 56 (BM, SING); ibidem, 1892, Ridley 3368 (BM); ibidem, Ridley s.n. (BM); ibidem, 5 Jan 1916, Burkill 1388 (KEP); Gardens, 1895, Ridley 6821 (BM); ibidem, 1902, Ridley 11337 (BM); Bukit Timah, 8 Aug 1900, Ridley s.n. (BM); ibidem, 15 Dec 1937, Corner SFN 34620 (K, SING [2 sheets]); ibidem, 23 Dec 1937, Corner SFN 34631 (SING [2 sheets]); ibidem, 14 Jun 1939, Ngadiman SFN 36455 (K, SING [2 sheets]); Bukit Timah Reserve, 2 Nov 1938, Ngadiman SFN 35935 (KEP, SING [2 sheets]); ibidem, 16 Feb 1939, Ngadiman SFN 36196 (BM, KEP, SING); ibidem, 15 Dec 1939, Ngadiman SFN 36131 (KEP, SING); ibidem, 15 Dec 1939, Ngadiman SFN 35508 (KEP, SING [2 sheets]); Reservoir Jungle, 29 Feb 1940, Corner SFN 36132 (KEP, SING [2 sheets]); Chan Chu Kang, 1896, Ridley 8056 (SING); Admiralty Road West, 26 Mar 2014, Lua SING2014-106 (SING); between Upper and Lower Peirce Reservoirs, 11 Feb 1982, Maxwell 82-36 (SING); Nassim Hill, Ridley 1183? (SING); Cluny Road, 1899, Ridley 10640 (SING); ibidem, 12 May 1992, Khng et al. 936 (SING); Temple Trail of Chestnut Avenue, 28 Dec 2010, Dempsey SING2010924 (SING); Chestnut Peninsula, Butterfly Trail, 13 Mar 2020, Lim SING2020-436 (SING); Mandai Forest, 17 Feb 2011, Lua \& Hassan SING2011-034 (SING); Upper Seletar Reservoir, 22 Feb 2011, Leong et al. SING2011-053 (SING); Mandai Road, near Upper Seletar Reservoir, 15 Feb 2011, Leong et al. SING2011-066 (SING); Seletar track, 16 Dec 2008, Gwee et al. SING2011-537 (SING); MacRitchie Reservoir, 15 Sep 2011, Boo SING2011-357 (SING); Dairy Farm Flyover, 1 Oct 2012, Yeo SING2012-419 (SING); Old Upper Thomson Road, 25 Aug 1994, Tang \& Sidek 7 (SING); Nee Soon Swamp, 8 Mar 1977, Samsuri SA 1446 (SING); Pulau Tekong, 3 Jan 2002, Samsuri et al. 278 (SING); ibidem, Reservoir Hill, 22 Feb 2001, Samsuri et al. 389 (SING); Pulau Brani, 1902, Ridley 11319 (SING).

Notes. This species is completely glabrous on the leaves and twigs in Peninsular Malaysia and Singapore, but in Borneo there are specimens with sparse, erect hairs on the undersides of the leaves and on the twigs.

Only one gathering was cited as type material for the name Litsea scortechinii by Gamble (1910b: 362): Scortechini 866. The specimen in K [K000797077] is designated here as the lectotype as it has numerous flowers and the card with characteristic drawings and dissection made by Gamble.

In the original description of Litsea elliptica by Blume (1826: 563) the only data given was that it had been collected in August, from Salak, and that it has the local name Huru Merang. Only three Blume specimens of this species from Salak are available for lectotypification, one from L [L0036670], one from U [U0002803], and one from BO [sheet no. BO-1274910]. The L specimen from this gathering is designated here as the lectotype.

Only one gathering was cited as type material for the name Litsea petiolata by Hooker (1886: 171): Maingay 1998 [Kew distribution no. 1265]. The K sheet of this gathering [K000797128] is designated here as the lectotype. 
13. Litsea erectinervia Kosterm., Reinwardtia 8: 94 (1970); Kochummen in Ng, Tree Fl. Malaya 4: 155 (1989). - TYPE: [Indonesia], Sumatra, Simaloer Islands, Tapah (Defajan), 26 August 1919, Achmad 1338 (lectotype BO [sheet no. BO-1276855], designated here; isolectotypes BO [sheet no. BO-1276856, BO-1278280]). (Fig. 10A).

Litsea ferruginea auct. non (Blume) Blume: Ridley, J. Straits Branch Roy. Asiat. Soc. 33: 132 (1900); Gamble, J. Asiat. Soc. Bengal, Pt. 2, Nat. Hist. 75: 186 (1912); Keng, Concise Fl. Singapore, vol. 1, Gymn. Dicot. 19 (1990).

Tree 5-30(-40) $\mathrm{m}$ tall, dbh 15-60 $\mathrm{cm}$. Twigs slender, 2.3-4.8 $\mathrm{mm}$ thick, round to angled in cross-section, velutinous; hairs reddish brown, erect; terminal leaf bud ovate, 7.9-8.8 mm long, apex acute, velutinous. Leaves alternate, with a strong smell when crushed; leaf blade leathery, elliptic to oblanceolate, 7.8-23 × 3.4-9 cm, apex acute, base cuneate, often asymmetric, drying dark to light brown; secondary veins 6-12 pairs, arching gradually towards the margin; tertiary veins scalariform; surface above glossy bright to dark green when fresh, glabrous with some hairs on the main vein, main vein and secondary veins flat to sunken, tertiary veins distinct; surface below glaucous, densely to sparsely hairy, main vein and secondary veins raised, tertiary veins faint; hairs reddish brown, erect; petiole half-terete to channelled, 7-25 mm long, sparsely to densely hairy (hairs erect). Inflorescences clusters of umbels, 1.3-1.5 $\mathrm{cm}$ long, arranged along branchlets or in axils of leaves, velutinous (hairs dark brown, erect); bracts $2-5$, suborbicular or broadly ovate, concave, 3-4×2-3.5 mm, velutinous outside, sparsely hairy inside; infructescence with $2-5$ fruits. Flowers cream to dark yellow, rarely pink; male flowers $6-8$ in each umbel, perianth lobes 6 , oblong, apex acute to rounded, 1.5-3 $\times 0.5-1 \mathrm{~mm}$, velutinous, stamens 6 , unequal, $1-4 \mathrm{~mm}$ long, hairy, anthers $0.5-1 \mathrm{~mm}$ long; female flowers c. 5 in each umbel, perianth lobes 6 , $1-3 \times 0.8-1 \mathrm{~mm}$, velutinous, ovary c. $1 \mathrm{~mm}$ in diameter, glabrous, style $1-2 \mathrm{~mm}$ long, stigma peltate. Fruits globose, $10-17 \mathrm{~mm}$ in diameter, apex rounded, surface warty except smooth at apex, yellow to red when mature; cupule woody, $12.5-20 \mathrm{~mm}$ in diameter, 4-9.5 $\mathrm{mm}$ deep, covering up to half of fruit, surface warty, grey; stalk unknown.

Distribution. Peninsular Malaysia, Singapore, Sumatra and Borneo (see Fig. 11).

Ecology. Growing in wet areas in lowland forest or swamps, at 0-280 m altitude. Flowering from April to May; fruiting from November to January.

Provisional IUCN conservation assessment. This species is known from about 11-15 localities and has a relatively large extent of occurrence (EOO of 726,928 $\left.\mathrm{km}^{2}\right)$ and area of occupancy (AOO of $56 \mathrm{~km}^{2}$ ) and therefore an assessment of globally Least Concern is proposed. 

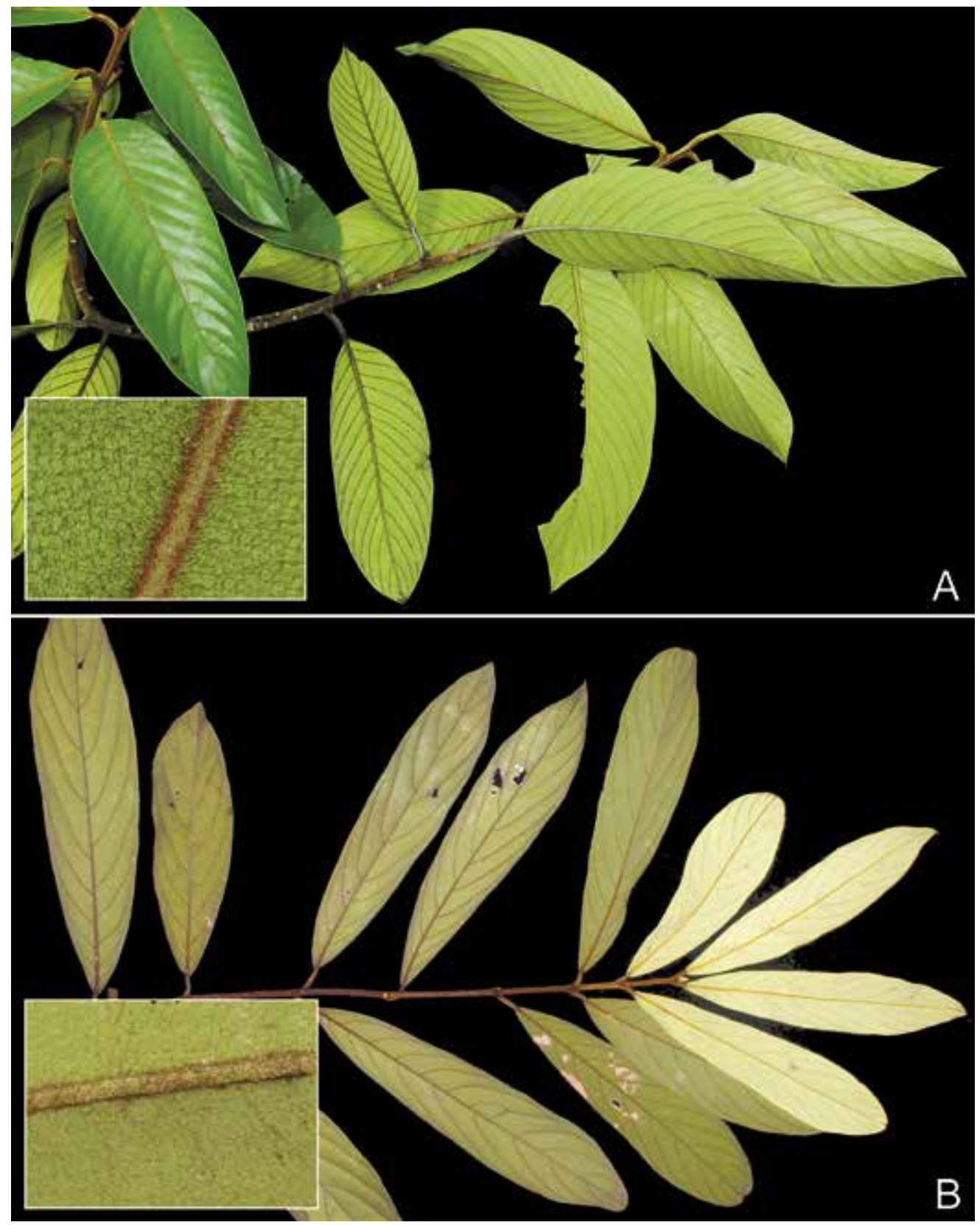

Fig. 10. A. A leafy branch of Litsea erectinervia Kosterm. showing alternate leaf arrangement. Inset: Close up of hairy vein on leaf. B. A leafy branch of Litsea ferruginea (Blume) Blume showing alternate leaf arrangement. Inset: Close up of hairy vein on leaf. From Singapore; A from Bukit Timah Nature Reserve, Niissalo SING2019-912; B from Rifle Range Road area. (Photos: A, P.K.F. Leong; B, X.Y. Ng). 


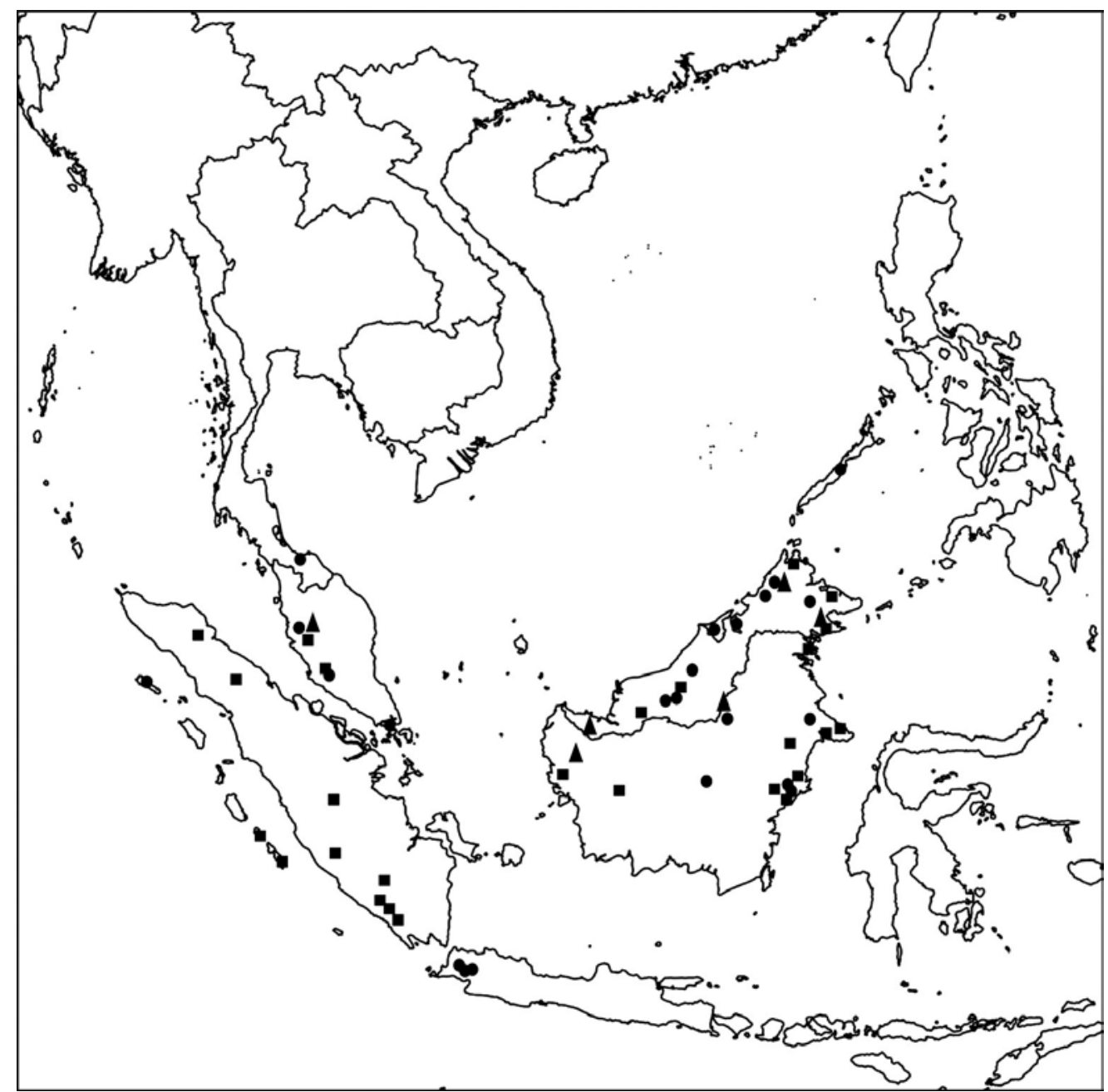

Fig. 11. Distribution of Litsea erectinervia $(\boldsymbol{\bullet})$, L. fenestrata $(\boldsymbol{\Delta})$ and L. ferruginea $(\bullet)$.

Specimens examined. PENINSULAR MALAYSIA: Perak: Taiping, Jan 1886, King's Collector 8437 (BM, K); ibidem, Pondok Tanjung, 22 Jul 1927, Payee 8045 (KEP); Larut, Apr 1885, King's Collector 7546 (K [2 sheets]); ibidem, Nov 1884, King's Collector 6826 (BM, K [3 sheets], SING); ibidem, Goping, May 1884, King's Collector 6039 (K [3 sheets], SING [3 sheets]). Pahang: Sungai Taku, 21 Feb 1968, Mhd Shah MS 1383 (K, KEP); Tahan Woods, 21 Feb 1968, Whitmore FRI 4790 (KEP).

SINGAPORE: s.l., Cantley's Collector s.n. (SING); Mandai Road, 25 Jul 1940, Corner SFN 37132 (SING); ibidem, 25 Apr 1934, Corner SFN 28093 (BM, K [2 sheets], KEP, SING); Bukit Arang, 1894, Ridley 5854 (BM, K, SING); Bukit Timah Reserve, 6 Apr 1938, Ngadiman SFN 36391 (BM, K, KEP [2 sheets], SING); Bukit Timah Nature Reserve, Tiup Tiup stream, 18 Sep 2019, Niissalo SING2019-912 (SING); Seletar Road, Apr 1894, Ridley 6151 (K [2 sheets], SING); Seletar Forest, Nee Soon, rifle range, 8 May 1954, Sinclair SFN 40279 (K, SING); Nee Soon Swamp Forest, 3 Aug 2010, Gwee SING2010-440 (SING); Nee Soon Pipeline, 24 Jan 2005, Lee et al. SING2005-07 (SING). 
Notes. This species is part of a small group with densely hairy brown twigs, terminal leaf buds, leaf undersurfaces and inflorescences. In Peninsular Malaysia and Singapore there are only two representatives of this group (Litsea erectinervia and L. ferruginea) and the differences between them are set out in Table 1.

Both Ridley (1900) and Gamble (1912) referred to this species as Litsea ferruginea, whereas Kostermans (1970), in his original description of L. erectinervia, stated that the differences between his new species and L. ferruginea were in the leaf arrangement, the midrib on the upper surface and the cupule. Keng (1990) in his Concise Flora of Singapore mistakenly reversed the two names. Chong et al. (2016), in their key to the Lauraceae species of Nee Soon Swamp Forest, discussed some of the characters. This confusion was compounded by Kostermans who named many specimens of this species in the late 1960s and early 1970s in various herbaria either as L. ferruginea or "L. ferruginiopsis", a name that he never published.

In the original description of Litsea erectinervia (Kostermans, 1970: 94) only one gathering is mentioned: Achmad 1338. There are three specimens [BO-1276855, BO-1276856, BO-1278280] of this gathering in BO, where Kostermans worked. The last one is sterile, while the first two have mature fruits. The specimen [BO-1276855], with the most complete label data, is designated here as the lectotype.

14. Litsea fenestrata Gamble, Bull. Misc. Inform. Kew 1910: 360 (1910); Ridley, Fl. Malay Penins. 3: 123 (1924); Kochummen in Ng, Tree Fl. Malaya 4: 156 (1989). - TYPE: [Peninsular Malaysia], Perak, Larut, April 1884, King's Collector 5938 (lectotype K [K000797087], designated here; isolectotypes BM [BM000799102], K [K000797086, plus specimen with no barcode]).

Tree 25-30 m tall, dbh 18-80 cm; bark smooth, greyish, with large lenticels, inner bark yellowish, aromatic, sapwood pale yellow. Twigs stout, 4.5-5.5 mm thick, round to strongly angular in cross-section, glabrous, pale brown; terminal leaf bud 12-16 mm long, lanceolate, apex acute, glabrous. Leaves alternate; leaf blade thickly leathery, elliptic or obovate, $15-35 \times 6-12.5 \mathrm{~cm}$, apex obtuse to acute, base cuneate, sometimes unequal, drying yellowish green; secondary veins $10-15$ pairs, curving near the margin; tertiary veins reticulate; surface above glabrous, midrib sunken, secondary veins flattened to sunken, tertiary veins indistinct; surface below glabrous, slightly glaucous, midrib and secondary veins raised, tertiary veins faintly visible; petiole half-terete, 13-21 mm long, swollen at the base, glabrous, wrinkled when dried. Inflorescences clusters of umbels, $0.7-1.8 \mathrm{~cm}$ long, arranged along the branchlets, glabrous; bracts suborbicular, concave, 6-7 $\times 3.7-4.5 \mathrm{~mm}$, velutinous; infructescence with 1-5 fruits. Flowers white; male flowers 6-7 in each umbel, perianth lobes 6 , oblong, 3.7-4 × 1-1.2 mm, apex rounded, sparsely hairy, stamens 12, unequal, 1.6-3.7 mm long, hairy, anthers 1-1.5 mm long; female flowers unknown. Fruits globose, 19-23 mm in diameter, apex rounded, smooth, glabrous, white; cupule 14-31 × 12-19 $\mathrm{mm}$, woody, surface pustulate, at first completely enclosing fruit with circular orifice at apex, later covering only lower half; stalk 5-6 5 5.6-6 mm, swollen. 
Table 1. Differences between Litsea erectinervia and L. ferruginea s.s.

\begin{tabular}{llll}
\hline & $\begin{array}{l}\text { Leaf } \\
\text { arrangement }\end{array}$ & $\begin{array}{l}\text { Terminal leaf } \\
\text { bud }\end{array}$ & Leaf colour when dried \\
\hline L. erectinervia & Alternate & Ovoid & Dark green \\
L. ferruginea s.s. & Opposite & Elliptic & Light yellowish green \\
\hline
\end{tabular}

Distribution. Peninsular Malaysia and Borneo. In Peninsular Malaysia, it is only known from Perak (see Fig. 11).

Ecology. Growing in lowland forest, including swamps. Flowering in April; fruiting in July.

Provisional IUCN conservation assessment. This species is only known from six scattered localities and has a relatively large extent of occurrence (EOO of 683,061 $\mathrm{km}^{2}$ ), but a small area of occupancy $\left(\mathrm{AOO}\right.$ of $\left.24 \mathrm{~km}^{2}\right)$. The lowland forest where it grows is under threat of deforestation and destruction. Given these facts, it is assessed here as Vulnerable (B2ab(i,ii,iii)).

Specimen examined. PENINSULAR MALAYSIA: Perak: Larut, King's Collector 6859 (BM, $\mathrm{K})$.

Notes. Three gatherings were cited in the protologue for the name Litsea fenestrata by Gamble (1910b: 360): King's Collector 5938, 6859 and Haviland 3088. The specimen in K [K000797087] of King's Collector 5938 is designated here as the lectotype as it has numerous flowers and the card with characteristic drawings and dissection made by Gamble.

15. Litsea ferruginea (Blume) Blume, Bijdr. Fl. Ned. Ind. 11: 561 (1826); Ridley, Fl. Malay Penins. 3: 129 (1924); Kostermans, Reinwardtia 8: 96 (1970). - Cryptocarya ferruginea Blume, Cat. Gew. Buitenzorg 65 (1823). - Tetranthera blumei Wall., Pl. Asiat. Rar. 2: 65 (1831), nom. illeg. - Actinodaphne blumei Nees, Syst. Laur. 598 (1836), as 'blumii', nom. illeg. - Cylicodaphne ferruginea (Blume) Blume, Mus. Bot. 2: 11 (1856). - Lepidadenia ferruginea (Blume) Miq., Fl. Ned. Ind. 1: 935 (1858). - Litsea blumei Hook.f., Fl. Brit. India 5: 160 (1886), nom. illeg.; Ridley, Fl. Malay Penins. 3: 129 (1924). - Malapoenna ferruginea (Blume) Kuntze, Revis. Gen. Pl. 2: 572 (1891). - TYPE: [Indonesia], Java, Salak, January 1823, Blume s.n. (lectotype L [L0036676], designated here). (Fig. 10B). 
Litsea griffithii Gamble, J. Asiat. Soc. Bengal, Pt. 2, Nat. Hist. 75: 187 (1912); Ridley, Fl. Malay Penins. 3: 129 (1924); Keng, Concise Fl. Singapore, vol. 1, Gymn. Dicot. 19 (1990). - TYPE: Singapore, Reservoir Woods, 1893, Ridley 4823 [mistakenly as 5823 in protologue] (lectotype K [no barcode], designated by De Kok, Gard. Bull. Singapore 69: 174 (2017); isolectotype SING [SING0043342]).

Litsea erectinervia auct. non Kosterm.: Keng, Concise Fl. Singapore, vol. 1, Gymn. Dicot. 19 (1990).

Tree 6-25 m tall, dbh 26-90 cm, buttresses to $1 \mathrm{~m}$ high; bark dark grey or dark brown, smooth, inner bark yellow to orange-yellow, rarely brown. Twigs slender to stout, 2.7-6.5 mm thick, round to angular in cross-section, velutinous; hairs erect, dark brown, short; terminal leaf bud ellipsoid, 5.6-9 $\mathrm{mm}$ long, velutinous. Leaves opposite; young leaves pinkish orange; leaf blade elliptic to obovate, $(6-) 8.3-42 \times(2-) 5-15$ $\mathrm{cm}$, apex acute to rounded, base cuneate, drying greenish yellow; secondary veins 8-12 pairs, looping near the margin; tertiary veins reticulate; surface above glabrous, dark or bright green, midrib and secondary veins raised to flattened, tertiary veins inconspicuous; surface below sparsely to densely hairy (hairs reddish brown, erect), glaucous, midrib and secondary veins raised, tertiary veins visible; petiole half-terete, swollen at base, 5-25 mm long, densely hairy (hairs reddish brown). Inflorescences clusters of umbels, $1.1-1.5 \mathrm{~cm}$ long, along branchlets or in axils of leaves, densely hairy, hairs dark brown, erect; bracts 5 , suborbicular or broadly ovate, concave, 5-6 $\times 3.5-6 \mathrm{~mm}$, velutinous outside, sparsely hairy inside; infructescence with $1-4$ fruits. Flowers cream to (pale) green or (bright) yellow; male flowers 6-8 in each umbel, perianth lobes $6,2-3 \times 0.5-1 \mathrm{~mm}$, oblong, apex acute to rounded, velutinous, stamens 6, unequal, 1-4 mm long, anthers 0.5-1 mm long; female flowers 6-7 in each umbel, perianth lobes $6,1-1.5 \times 0.5-0.7 \mathrm{~mm}$, velutinous, ovary $0.6 \mathrm{~mm}$ in diameter, glabrous, style 3-4 mm long, stigma peltate. Fruits globose to ellipsoid, 8-25 × 13-14 mm, apex rounded, surface warty except smooth at apex, dull red becoming black when mature; cupule fleshy, 15.6-19 $\mathrm{mm}$ in diameter, 11-16 $\mathrm{mm}$ deep, covering almost the entire fruit, surface smooth to warty.

Distribution. Peninsular Thailand, Peninsular Malaysia, Singapore, Sumatra, Java and Philippines (Palawan) (see Fig. 11).

Ecology. Growing in primary and secondary lowland and hill forests, from sea-level up to $330 \mathrm{~m}$ altitude. Flowering from September to June; fruiting from May to August.

\section{Vernacular name. Medang pinang.}

Provisional IUCN conservation assessment. This species is known from at least 15-30 localities and has a relatively large extent of occurrence (EOO of 417,910 $\mathrm{km}^{2}$ ) and area of occupancy (AOO of $60 \mathrm{~km}^{2}$ ). For these reasons, an assessment of globally Least Concern is proposed. 
Specimens examined. PENINSULAR MALAYSIA: Perak: Taiping, Feb 1886, King's Collector 8573 (BM, K); Chaugkat Jerin, Aug 1888, Wray 2757 (K); Larut, Apr 1884, King's Collector 5865 (K [3 sheets], SING); Parit F.R., 12 Apr 1937, Mat Jasin 34232 (KEP); ibidem, 16 Mar 1938, Mat Jasin 34286 (KEP). Kelantan: Machang, 4 Jul 2006, Teo \& Din KL 5266 (KEP). Terengganu: Dungun, Tanah Kerajaan Terengganu, 14 Jul 2010, Lim FRI 72816 (KEP). Pahang: Kuantan, Bukit Goh F.R., 15 Feb 1934, Ismail 17321 (KEP); Aur Forest, 11 May 1967, Whitmore FRI 3678 (K, KEP, SING); Jerantut, Gunung Aais F.R., 5 Jul 2004, Chung \& Angan RC 119 (SING); Jerantut, 4 May 1999, Teo \& Wintz KL 4890 (KEP). Selangor: Rantau Panjang, 8 May 1920, Walter 22082 (K, SING); Ulu Gombak, 20 Oct 1975, Kochummen FRI 23144 (K, KEP); Batang Berjuntai F.R., 31 May 1921, Hume 7501 (SING); Panjang Reserve, 2 Jan 1921, Ahmad 5776 (KEP). Kuala Lumpur: s.l., 30 May 1927, Omar 7987 (KEP); Weld Hill Reserve, Sep 27 Jul 1909, Burn-Murdock 282 (Ridley 14284) (BM, K, SING); ibidem, 26 Feb 1918, Rahman 2846 (KEP); ibidem, 28 May 1918, Hamid s.n. (SING); ibidem, 18 Nov 1918, Mat s.n. (KEP); ibidem, 20 May 1920, Ahmad 5028 (K, KEP, SING). Negeri Sembilan: Pasoh, 14 Jun 1989, Saw \& LaFrankie FRI 37275 (K, KEP); Sungai Menyala, 17 Jun 1947, Smith 64759 (KEP). Malacca: s.l., Griffith s.n. [Kew distribution no. 4285] (K [3 sheets]). Johor: Jaffaria, 28 Aug 1879, King \& Hullett s.n. (K [4 sheets]); Kluang F.R., 1 Feb 1968, Ng KEP 97984 (KEP); Meidury, 17 Mar 1992, Thomas \& Teo KL 4110 (KEP).

SINGAPORE: s.l., Cantley's Collector s.n. (SING); Garden's Jungle, 1893, Ridley 5569 (BM); Reservoir Woods, 1893, Ridley 4823 (K, SING).

Notes. This species is morphologically very similar to Litsea erectinervia (see there for a discussion of the morphological differences between them).

In the original description of Cryptocarya ferruginea (Blume, 1823: 65) the type material was said to have been gathered on Salak in Java in January 1823 by C.L. Blume. The L specimen [L0036676] with this data is designated here as the lectotype.

16. Litsea glabrifolia Ridl., J. Fed. Malay States Mus. 10: 152 (1920); Ridley, Fl. Malay Penins. 3: 119 (1924). - TYPE: [Peninsular Malaysia], Pahang, Gunung Senyum, June 1917, Evans s.n. (lectotype K [K000797071], designated here; isolectotypes BM [BM001209835], K [no barcode]).

Tree. Twigs slender, 2.7-3.5 mm thick, angular in cross-section, glabrous; terminal leaf bud ovoid, c. $4 \mathrm{~mm}$ long, apex acuminate, velutinous. Leaves alternate; leaf blade leathery, lanceolate, $17-22 \times 7-8 \mathrm{~cm}$, apex unknown, base cuneate; secondary veins 10-12 pairs, curving near the margin; tertiary veins reticulate; surface above glabrous, midrib and secondary veins sunken, tertiary veins distinct; surface below glaucous, sparsely hairy (hairs appressed, yellowish), midrib and secondary veins raised, tertiary veins indistinct; petiole half-terete, $9-18 \mathrm{~mm}$ long, slender to slightly swollen at base, glabrous. Inflorescences clusters of umbels, 1.1-2.3 cm long, velutinous; bracts 4, c. $3.8 \mathrm{~mm}$ long, boat-shaped, velutinous. Flowers: male flowers c. 7 per umbel, perianth lobes lanceolate, 3.3-3.5 × 1-1.1 mm, velutinous outside, glabrous inside, yellow, stamens 12, 4-6.5 mm long, sparsely hairy; female flowers unknown. Fruits unknown.

Distribution. Endemic to Peninsular Malaysia, where it is only known from Gunung Senyum in Pahang (see Fig. 12). 


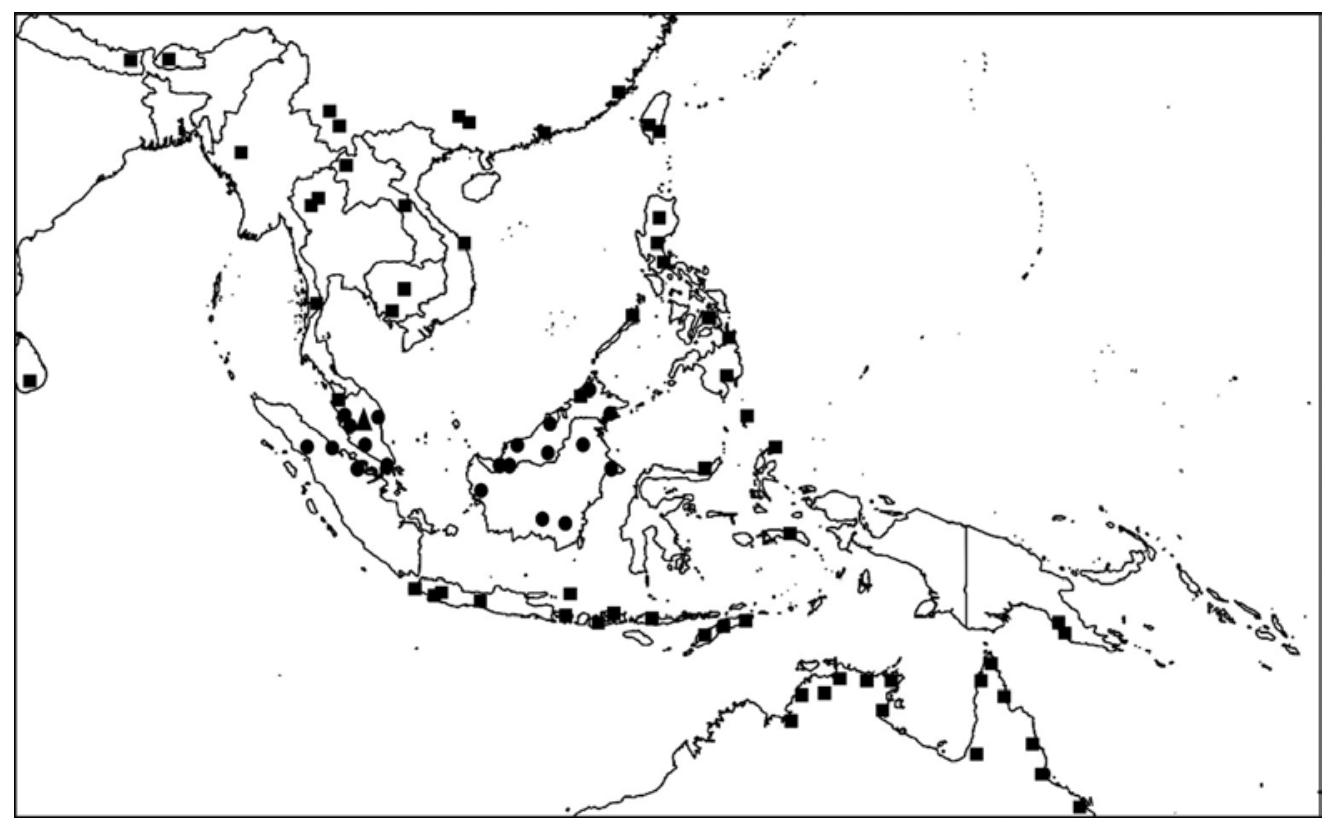

Fig. 12. Distribution of L. glabrifolia $(\mathbf{\Delta})$, Litsea glutinosa $(\boldsymbol{\bullet})$ and L. gracilipes $(\bullet)$.

Ecology. Habitat unknown. Flowering in June.

Provisional IUCN conservation assessment. This species is only known from one collection (made in 1916) from a single locality (Gunung Senyum in Pahang), which is now part of the Smiling Mountain Recreational Park. It is assessed here as Data Deficient.

Notes. In the original description of Litsea glabrifolia, Ridley (1920: 152) cited one gathering: Gunung Senyum, Evans s.n. There are two sheets of this gathering at K available for lectotypification and the one with open flowers and barcode is designated here as the lectotype.

17. Litsea glutinosa (Lour.) C.B.Rob., Philipp. J. Sci., C 6: 321 (1911); Grierson \& Long, Fl. Bhutan 1(2): 277 (1984); Kochummen in Ng, Tree Fl. Malaya 4: 157 (1989); Kostermans in Dassanayake et al., Revis. Handb. Fl. Ceylon 9: 148 (1995); Ngernsaengsaruay et al., Thai Forest Bull., Bot. 39: 54 (2011); Pendry in Watson et al., Fl. Nepal 3: 43 (2011). - Sebifera glutinosa Lour., Fl. Cochinch. 2: 638 (1790). Litsea sebifera Pers., Syn. P1. 2(1): 4 (1806), nom. illeg.; Ridley, Fl. Malay Penins. 3: 128 (1924); Liou Ho, Laurac. Chine \& Indochine 196 (1932). - TYPE: Cochinchina [Vietnam], Loureiro s.n. (lectotype BM [BM000951058], designated here).

Litsea brideliifolia Hayata, Icon. P1. Formosan. 5: 166 (1915). - Litsea glutinosa (Lour.) C.B.Rob. var. brideliifolia (Hayata) Merr., Lingnaam Agric. Rev. 1: 84 (1923); 
Kochummen in Ng, Tree Fl. Malaya 4: 157 (1989). - TYPE: [Published illustration] Hayata, Icon. Pl. Formosan. 5: 164, fig. b (1915) (lectotype designated here).

Tree 3-15 m tall, dbh 2-20 cm; bark smooth, greyish brown or grey. Twigs slender, 3.6$3.7 \mathrm{~mm}$ thick, velutinous when young, glabrescent; hairs yellowish, curly; terminal leaf bud ovate, 4-4.3 mm long, velutinous. Leaves spirally arranged; leaf blade chartaceous to coriaceous, elliptic to obovate, $5-25 \times 2.5-12 \mathrm{~cm}$, apex acute to rounded, base cuneate or oblique; secondary veins 6-13 pairs, curving or curving and looping near the margin; tertiary veins scalariform-reticulate; surface above glabrous, green or dark green, except densely hairy on midrib and secondary veins, midrib raised, secondary veins raised to sunken, tertiary veins distinct; surface below glaucous, densely hairy, midrib and secondary veins raised, tertiary veins distinct; petiole half-terete, 10-30 $\mathrm{mm}$ long, densely hairy, not swollen. Inflorescences clusters of umbels, 2-6 cm long, arranged along branchlets or in axils of leaves, umbels $0.4-1.5 \mathrm{~cm}$ in diameter; bracts 4, decussate, suborbicular, concave, 3.5-7 × 3-7 mm, coriaceous, ciliate, densely hairy outside, hairy inside (hairs yellowish brown, curly). Flowers white to greenish; male flowers $10-15$ in each umbel, perianth lobes $0-3$, oblong, unequal, $2.5-3 \times 0.5-1 \mathrm{~mm}$, hairy, stamens 10-18, unequal, 2-4 mm long, hairy, anthers $0.8-1 \mathrm{~mm}$ long; female flowers 9-11 in each umbel, perianth lobes unknown, ovary globose, $0.8-1 \mathrm{~mm}$ in diameter, glabrous, style 2-2.5 mm long, stigma peltate. Fruits globose, 7-10 × 10-12 $\mathrm{mm}$, apex rounded, smooth, glabrous, glossy, red to dark purple or black when mature; cupule shallow, 4-8 $\mathrm{mm}$ in diameter, smooth, sparsely hairy, margins entire; stalk 2-5 $\mathrm{mm}$ long, sparsely hairy, not swollen.

Distribution. India, Nepal, Bhutan, Sri Lanka, China, Myanmar, Thailand, Cambodia, Laos, Vietnam, Peninsular Malaysia, Borneo, Java, Lesser Sunda Islands, Sulawesi, Moluccas, Philippines, New Guinea and Australia (see Fig. 12). In Peninsular Malaysia only known from Kedah.

Ecology. Known from a wide variety of habitats but in Peninsular Malaysia only known from limestone hills at 0-200 m altitude (0-1450 m altitude elsewhere). Flowering from February to July; fruiting from June to November.

Vernacular name. Medang Telor.

Provisional IUCN conservation assessment. This species has a very wide distribution and a large population and so is not currently experiencing any major threats and no significant future threats have been identified. An assessment of globally Least Concern is therefore proposed.

Specimens examined. PENINSULAR MALAYSIA: Kedah: Balu 15 sentok, 22 Feb 1935, Abdullah 33067 (KEP); Gunung Jerai Reserves, 6 Jun 1931, Unknown 21917 (KEP); South Rotan, 13 May 1954, Ashed 21935 (KEP); Gunung Baling, 8 May 1938, Kiah SFN 35372 (KEP); Gunung Baling, 19 Jul 1956, Unknown 72555 (KEP). 
Notes. Ridley (1924: 128) stated that this species is occasionally planted and is unlikely to be native to Peninsular Malaysia. It may indeed be planted at some localities, but this is not likely to be the case for all and the general distribution of the species suggests it is native.

The variety Litsea glutinosa var. brideliifolia was thought to be a form with smaller leaves with rounded apices (Kochummen, 1989: 157). However, this variety falls within the general range of variation of the species across its distribution.

In the original description of Sebifera glutinosa by Loureiro (1790: 638) no specimens are cited. The only known Loureiro specimen of this species [BM000951058] is designated here as the lectotype.

I could not find any type material for the name Litsea brideliifolia Hayata (Hayata, 1915), therefore I am designating the plate in the original publication as the lectotype here.

18. Litsea gracilipes Hook.f., Fl. Brit. India 5: 159 (1886); Ridley, Fl. Malay Penins. 3: 130 (1924); Kochummen in Ng, Tree Fl. Malaya 4: 157 (1989). - TYPE: [Peninsular Malaysia], Malacca, Griffith s.n. [Kew distribution no. 4311] (lectotype K [K000797135], designated by De Kok, Gard. Bull. Singapore 69: 174 (2017); isolectotypes K [K000797136], P [P00745274]).

Tree 9-21 m tall, dbh 7-40 cm; trunk with short buttresses and, occasionally, stilt roots; bark dark to reddish brown, smooth and lenticellate with horizontal rings, inner bark yellow-brown, rapidly darkening on exposure, with strong aromatic smell, sapwood yellow. Twigs slender, 1.8-2.6 mm thick, round in cross-section, glabrous; terminal leaf bud lanceolate, 2.5-3.4 mm long, apex acute, velutinous. Leaves mainly (sub)opposite, some alternate; leaf blade (thinly) leathery, elliptic to obovate, (3.5)7.5-14 × (1.6-) $2.5-6.5 \mathrm{~cm}$, apex acute to sharply acute, often with a distinct tip, base cuneate to attenuate; secondary veins 5-8 pairs; tertiary veins finely reticulate; surface above glabrous, pale to dark green, midrib and secondary veins sunken, secondary and tertiary veins inconspicuous; surface below glabrous, midrib and secondary veins raised, tertiary veins visible; petiole half-terete, 7-12 $\mathrm{mm}$ long, glabrous, wrinkled when dry. Inflorescences clusters of umbels, 1.1-2 cm long, arranged along branchlets or in axils of leaves; umbels 4-5 mm in diameter, densely to sparsely hairy; bracts 4 , $3.5-5 \times 1.5-3 \mathrm{~mm}$, orbicular to oblong, densely to sparsely hairy outside. Flowers yellowish green; male flowers 4 in each umbel, perianth lobes 6, obovate-oblong or oblong, apex acute, $2-2.2 \times 0.8-1.1 \mathrm{~mm}$, sparsely hairy, stamens $9-10$, unequal, 2-4 mm long, glabrous, anthers $0.8-1.3 \mathrm{~mm}$ long; female flowers c. 4 in each umbel, perianth lobes 6 , obovate-oblong or oblong, 1.2-1.7 × 0.5-1 mm, ovary globose, $0.9-$ $1 \mathrm{~mm}$ in diameter, glabrous, style $2-2.1 \mathrm{~mm}$ long, stigma peltate. Fruits ellipsoid, 8-16.6 × 4-10 mm, apex rounded, glabrous; cupule 5-7.2 $\mathrm{mm}$ in diameter, margins entire, smooth, covering the base of the fruit, glabrous to sparsely hairy; stalk slightly swollen, 2-2.2 mm thick. 
Distribution. Peninsular Malaysia, Singapore, Sumatra and Borneo (see Fig. 12).

Ecology. Growing in fresh water and peat swamps, from 0-120 m altitude. Flowering from June to August; fruiting from October to February.

Vernacular name. Medang kasai.

Provisional IUCN conservation assessment. This species is known from about 4050 localities and has a very large extent of occurrence (EOO of 1,368,798 $\mathrm{km}^{2}$ ) and area of occupancy (AOO of $120 \mathrm{~km}^{2}$ ) and therefore an assessment of globally Least Concern is proposed.

Specimens examined. PENINSULAR MALAYSIA: Perak: s.l., Jan 1884, King's Collector 5455 (BM, K [3 sheets]); Larut, Jan 1884, King's Collector 5421 (K [3 sheets], SING [2 sheets]); Hutan Melintang, 13 Sep 1967, Ng FRI 5703 (K, KEP, SING). Pahang: Kuantan, 5 Dec 1924, Burkill \& Haniff 17529 (KEP, SING). Selangor: Klang, Telok, 12 Jun 1921, Burkill 6515 (K, KEP, SING); ibidem, 21 Nov 1930, Symington KEP 24572 (K, KEP, SING); ibidem, 24 Nov 1936, Symington KEP 42980 (KEP); ibidem, 26 Jul 1937, Dom 41665 (KEP); ibidem, 20 May 1938, Symington KEP 47103 (K, KEP); ibidem, Telok F.R., 9 Nov 1953, Sinclair SFN 40110 (BM, SING [2 sheets]); ibidem, 9 Nov 1953, Sinclair SFN 40106 (K, KEP); ibidem, 16 Nov 1961, Kochummen FRI 95094 (K, KEP, SING); ibidem, 30 Apr 1963, Ismail KEP 98866 (K, KEP); ibidem, 17 Feb 1966, Kochummen FRI 98561 (K, KEP, SING); ibidem, 25 Aug 1966, Chelliah FRI 98695 (KEP); ibidem, Telok Swamp Forest, 7 Jun 1968, Whitmore FRI 8857 (KEP); ibidem, 4 Jul 1978, Suppiah FRI 28201 (KEP); ibidem, Changgaug, 5 Oct 1937, Nur SFN 34012 (K, KEP, SING); Sungei Karang, 3 Nov 1992, Chua et al. FRI 38801 (KEP); Sungei Tangi, Tanjung Karang, 17 Apr 1980, Vethevelu FRI 25390 (K, KEP, SING); ibidem, 17 Apr 1980, Vethevelu FRI 25388 (KEP, SING). Malacca: Malimau, 17 Apr 1886, Alvins s.n. (SING); Benting F.R., 9 Nov 1953, Sors \& Lindong KEP 76024 (K, KEP, SING). Johor: Tanjong Kupang, 1894, Ridley 6457 (BM, K, SING); Pontian, 3 Jul 1939, Ngadiman s.n. (SING); Mawai, 9 Jun 1924, Corner SFN 28451 (K, KEP, SING); ibidem, 9 Jun 1924, Corner SFN 28452 (K, KEP, SING); Kuala Sedili New Road, 28 Jun 1959, Kadim \& Noor KN 244 (SING).

SINGAPORE: path leading to rifle range, Nee Soon, Seletar Forest, 1 May 1954, Sinclair SFN 40274 (K, SING); Bukit Timah Nature Reserve, Jalan Kutu, 1 Aug 1969, Noor MN 404 (SING).

19. Litsea grandis (Nees) Hook.f., Fl. Brit. India 5: 162 (1886); Ridley, J. Straits Branch Roy. Asiat. Soc. 33: 131 (1900); Ridley, Fl. Malay Penins. 3: 115, fig. 145 (1924); Liou Ho, Laurac. Chine \& Indochine 191 (1932); Corner, Wayside Trees Mal. 347 (1940); Kochummen in Ng, Tree Fl. Malaya 4: 158 (1989); Keng, Concise Fl. Singapore, vol. 1, Gymn. Dicot. 19 (1990); Ng, Gard. Bull. Singapore 57: 233 (2005); Ngernsaengsaruay et al., Thai Forest Bull., Bot. 39: 57 (2011). - Tetranthera grandis Wall., Numer. List 2552 (1830), nom. nud. - Polyadenia grandis Nees in Wallich, P1. Asiat. Rar. 2: 62 (1831); Nees, Syst. Laur. 574 (1836). - TYPE: [Malaysia], Penang, October 1822, Porter s.n. [EIC 2552] (lectotype K-W [K001116410], designated by 
Ngernsaengsaruay et al., Thai Forest Bull., Bot. 39: 57 (2011); isolectotypes BM, E [E00393267], K [K000797041, K000797043]). (Fig. 13).

Litsea rufofusca Kosterm., Reinwardtia 7: 352 (1968), syn. nov. - Litsea grandis (Nees) Hook.f. var. rufofusca (Kosterm.) Ng, Gard. Bull. Singapore 57: 233 (2005). - TYPE: [Indonesia], Kalimantan, Sampit, 30 September 1941, Versteegh bb. 33044 (holotype L [L0036810]).

Litsea paludosa Kosterm., Reinwardtia. 8: 103 (1970), syn. nov. - Litsea grandis (Nees) Hook.f. var. paludosa (Kosterm.) Ng, Gard. Bull. Singapore 57: 233 (2005). TYPE: [Malaysia], Sarawak, Simanggang, Anderson S 14520 (holotype BO; isotypes SAR, SING [SING0294229]).

Litsea polyantha sensu Ridley, J. Straits Branch Roy. Asiat. Soc. 33: 132 (1900).

Tree 10-30 m tall, dbh 15-80 cm; bark smooth to scaly, lenticellate, greyish brown, inner bark pale brown to yellowish, strongly aromatic, sapwood yellowish. Twigs slender to stout, 4-12 mm thick, angular in cross-section, velutinous; hairs reddish brown, short, erect; terminal leaf buds 8-19 mm long, apex acute, velutinous. Leaves alternate, crowded towards the apex of branchlets; leaf blade stiff, leathery, elliptic, sometimes ovate or obovate, $8-38 \times 6-18.5 \mathrm{~cm}$, apex rounded to acute, sometimes emarginate, base rounded to cuneate, sometimes oblique, margins wavy; secondary veins 7-14 pairs, curving and looping near the margin; tertiary veins scalariformreticulate; surface above glabrous or hairy on the midrib and secondary veins only, midrib and secondary veins sunken, tertiary veins distinct; surface below sparsely to densely hairy, sometimes glaucous, midrib and secondary veins strongly raised, tertiary veins distinct; petiole half-terete, 8-32 $\mathrm{mm}$ long, velutinous (hairs brown). Inflorescences clusters of umbels, $1.5-2.5 \mathrm{~cm}$ long, arranged along branchlets or in axils of leaves, umbels $0.7-1.2 \mathrm{~cm}$ in diameter; bracts 4 , decussate, suborbicular or broadly ovate, concave, 4-7 $\times 3-5 \mathrm{~mm}$, coriaceous, densely hairy (hairs reddish brown). Flowers: male flowers 5-7 in each umbel, perianth lobes 6, linear-oblong or oblong, 3.5-4 × 0.5-0.8 mm, sparsely hairy, stamens $15-18$, unequal, 2-5 mm long, glabrous to very sparsely hairy, anthers $1-1.5 \mathrm{~mm}$ long; female flowers 5-6 in each umbel, perianth lobes 6 , ovate or ovate-oblong, $1.5-3 \times 0.8-1 \mathrm{~mm}$, sparsely hairy, ovary ovoid, $1-1.2 \times 0.8-1 \mathrm{~mm}$, glabrous, style $1.5-2.5 \mathrm{~mm}$ long, stigma peltate. Fruits ellipsoid, 10-22 × 7-8(-13) mm, apex acute, smooth, glabrous, dark red or purple or black when ripe, glossy; cupule shallow, 4-5(-8) $\mathrm{mm}$ high, 6-7(-11) $\mathrm{mm}$ in diameter, sparsely pubescent, margins often wavy, entire; stalk slightly swollen, 7-14 $\times 2-3 \mathrm{~mm}$, sparsely hairy.

Distribution. Myanmar, Thailand, Peninsular Malaysia, Singapore, Sumatra, Borneo, Java, Sulawesi and Philippines (see Fig. 14). 


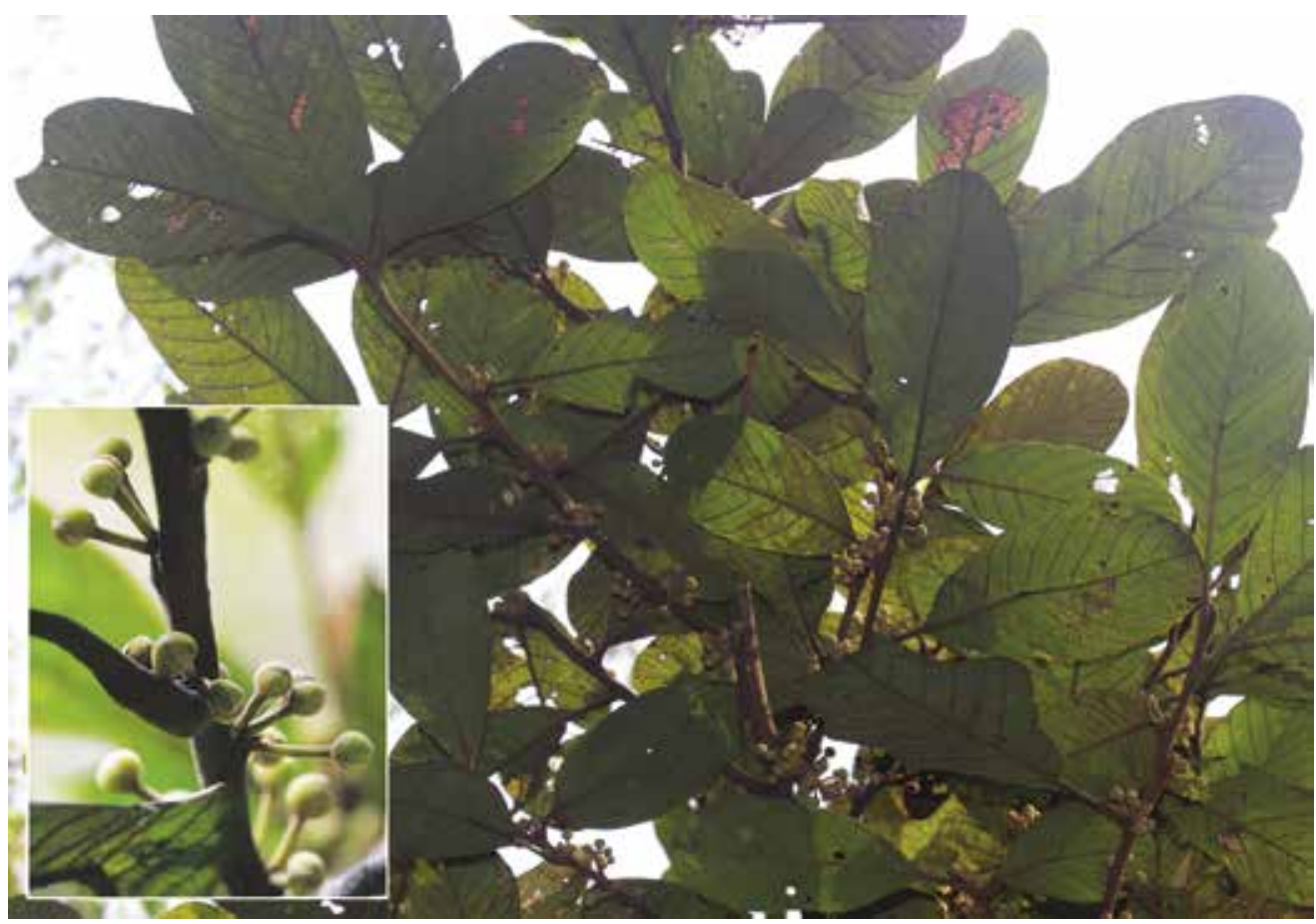

Fig. 13. Habit of Litsea grandis (Nees) Hook.f. Inset: Close up of flower buds. From Singapore, Central Catchment Nature Reserve. (Photos: X.Y. Ng).

Ecology. Growing in primary and secondary forests and in open vegetation, sometimes in (peat) swamp forest, at 0-1500 m altitude. Flowering from November to May; fruiting from February to December.

Vernacular names. Nyatoh, Medang telor, Medang keladi, Madang busuk, Medang lebar daun (Malay); Broad-leaved medang (Singapore).

Provisional IUCN conservation assessment. This species is known from at least 100150 localities and has a very large extent of occurrence (EOO of 5,049,070 $\mathrm{km}^{2}$ ) and area of occupancy (AOO of $304 \mathrm{~km}^{2}$ ). In view of these factors and its ability to grow in secondary vegetation, an assessment of globally Least Concern is proposed.

Specimens examined. PENINSULAR MALAYSIA: Kedah: 33 mile stone on Jeniang Road, 21 Oct 1938, Kiah SFN 35951 (SING); road to Kedah peak, 12 Mar 1971, Kochummen FRI 16333 (KEP); Bukit Perak F.R., 23 Nov 1969, Chan FRI 13124 (KEP, SING); Bukit Tangga F.R., 2 Oct 1959, Mat 42128 (KEP); Ulu Muda Forest, 17 Jan 1969, Chan FRI 6720 (KEP); Gunung Jerai, Dec 1925, Meh 9046 (KEP); Jalan Sintoh, 27 Sep 1951, Ariffin 21661 (KEP); Sina, 28 Apr 2006, Teo \& Din KL 5236 (KEP); Bukit Perak, 26 Nov 1969, Everett FRI 13687 (KEP, SING); Kuala Muda, 19 Dec 1946, Din bin Hasshim KEP 59617 (KEP, SING [2 sheets]); Kusial, 31 Dec 1949, Abdullah KEP 68052 (KEP, SING); garden of PWD house of South Pattani, 8 Jan 1939, Hoskins s.n. (SING); Pulau Langkawi, Kisap, Feb 1911, Haniff 


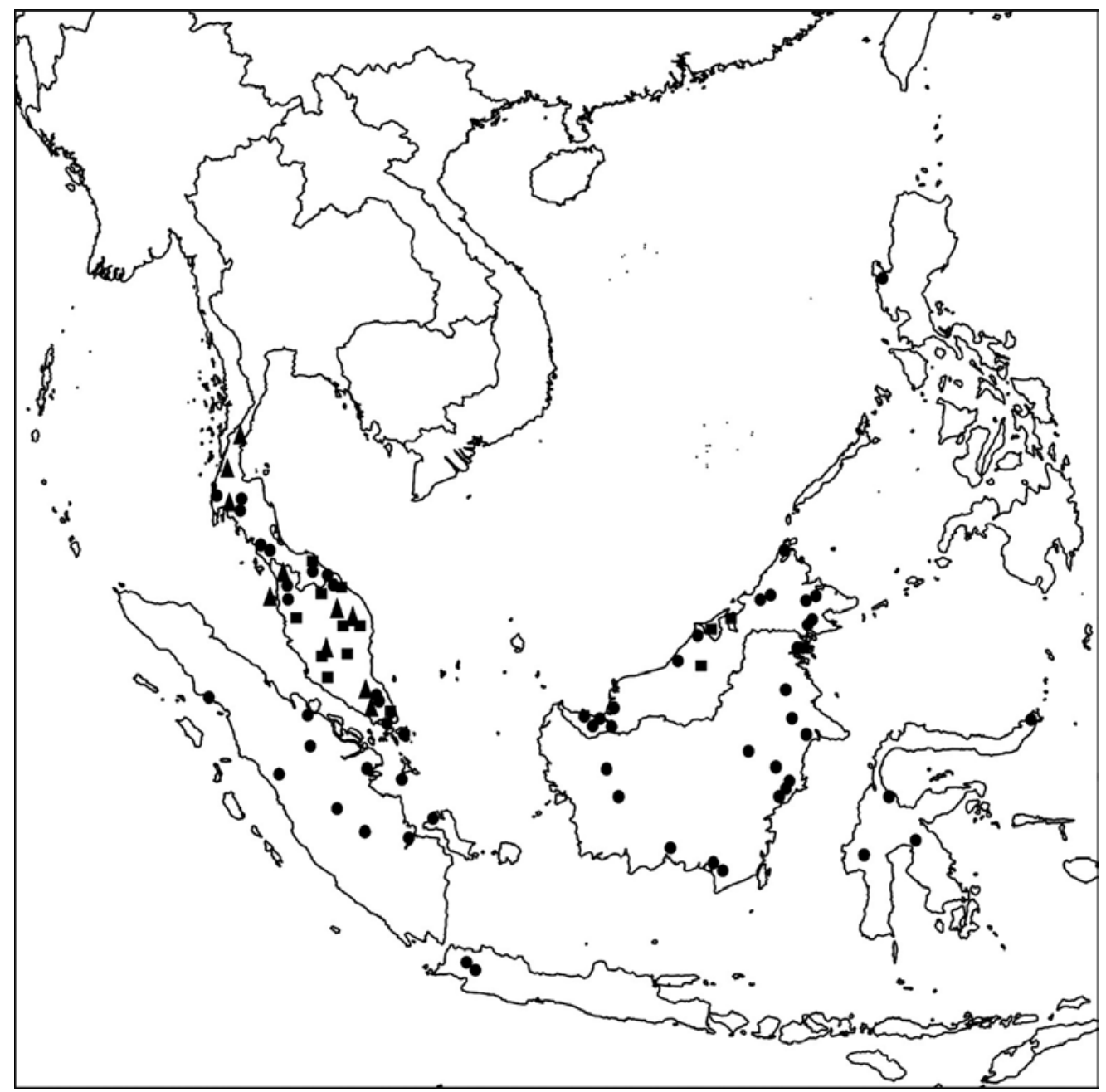

Fig. 14. Distribution of Litsea grandis $(\bullet)$, Litsea hirsutissima $(\boldsymbol{\Delta})$ and L. johorensis $(\mathbf{\square})$.

15471 (SING); ibidem, Apr 1929, Rahman 18035 (KEP, SING). Penang: Government Hill, 1886, Curtis 1104 (BM, SING); ibidem, Aug 1901, Curtis 1104 (SING [3 sheets]); ibidem, Ridley s.n. (BM). Perak: Goping, Apr 1884, King's Collector 5888 (SING [2 sheets]); ibidem, Sep 1886, King's Collector 10918 (BM); 5 miles from Tapah, Jan 1911, Burkill 383 (KEP, SING); Trolak F.R., 18 Mar 1967, Chelliah KEP 104617 (SING [2 sheets], KEP); Kinta Hill F.R., Kuala Liyang, Ipoh, 15 Oct 1966, Zainudin KEP 99781 (KEP, SING); Grik state land, 14 Nov 1966, Ismail KEP 95015 (KEP, SING). Kelantan: Kota Baru, 20 Apr 1937, Corner SFN 33407 (SING [4 sheets]); Kota Baru, 24 Apr 1937, Corner SFN 33460 (SING [2 sheets]); Gua Musang, 13 Nov 1992, Husmady FRI 39111 (KEP); Gobek, 7 Mar 1959, Mhd Shah \& Kadim MS 570 (SING); Pulai Chondong, 3 Feb 1970, Burgess FRI 15134 (KEP). Pahang: Fraser's Hill, 12 Aug 1937, Corner SFN 33183 (SING); ibidem, 4 Dec 1991, Kiew \& Anthony RK 3425 (SING); Bukit Changgang, 1 Oct 1937, Nur SFN 33956 (KEP, SING); Sekinchan, 3 Dec 1991, Lesmey FRI 33954 (KEP); Telok F.R., 25 Aug 1966, Chelliah KEP 98696 (KEP, SING); ibidem, 30 Apr 1963, Ismail KEP 98869 (KEP, SING); ibidem, 14 Mar 1967, Ng FRI 
1984 (KEP, SING); Kuala Selangor, 16 Oct 1930, Jappar 21971 (KEP, SING); Sungai Tongi, Tanjong Karang, 17 Apr 1960, Vethevelu FRI 25391 (SING); Jengka, 6 Mar 1979, Yap FRI 28421 (KEP); Taman Negara, Ulu Sat, 11 Jul 1970, Whitmore FRI 15244 (KEP). Selangor: Fraser's Hill, 18 Nov 1970, Kochummen FRI 16257 (KEP, SING). Kuala Lumpur: s.1., 1 Oct 1920, Ahmad 5409 (KEP, SING). Negeri Sembilan: Pengkalau Kempas Road, 22 Apr 1919, Go \& Tesope FMS 578 (KEP, SING). Johor: Segamat Wildlife Sanctuary, 1 Jun 1970, Everett FRI 14276 (KEP); Cameron Highlands, Lubok Tamang, Jan 1961, Quaife s.n. (SING [2 sheets]); Maikil Virgin Jungle Reserve, 23 Nov 1969, Loh FRI 6868 (KEP, SING); Muar, 4 Jun 1952, Abdullah KEP 74104 (KEP, SING); Messing, 3 Dec 1998, Teo \& Wintz KL 4851 (KEP); Sungai Kayu, 26 Oct 1936, Kiah SFN 32177 (SING [3 sheets]); Labis F.R., 4 Apr 1972, Chan FRI 19957 (KEP, SING); Ham Heng, 12 Dec 1927, Teruya 459 (SING).

SINGAPORE: s.l., Ridley s.n. (BM [3 sheets]); Chua Chu Kang, 1892, Ridley 3962 (BM, SING); Bukit Mandai, 1894, Ridley 5853 (BM, SING); Mandai Road, 29 Nov 1937, Corner SFN 34449 (K, SING [2 sheets]); Changi, Mar 1884, Ridley 4700 (BM); ibidem, 1890, Ridley 4700 (BM); Bukit Timah Reserve, 17 Mar 1937, Ngadiman SFN 36369 (BM, KEP, SING); Bukit Timah, 1900, Ridley 10859 (K [2 sheets], SING); ibidem, 5 Jan 1937, Ngadiman SFN 34654 (SING); ibidem, 12 Nov 1937, Ngadiman SFN 34525 (K, SING [2 sheets]); ibidem, 1 Dec 1937, Ngadiman SFN 34606 (K, SING); ibidem, 4 Feb 1938, Ngadiman SFN 34698 (K, SING); ibidem, 26 Feb 1938, Ngadiman SFN 34694 (K, KEP, SING); Selitan, 1894, Ridley 6452 (BM, SING); Botanic Gardens, 1894, Ridley 10698 (K [3 sheets], SING [2 sheets]); Botanic Gardens, Tanglin, 10 Mar 1900, Ridley 10802 (K); South side of MacRitchie Reservoir, 23 Jun 1955, Sinclair SFN 40646 (K, SING); ibidem, 6 Nov 1961, Soepadmo 264 (K); Nee Soon Swamp Forest, 17 Jun 2003, Samsuri et al. NES 214 (SING); ibidem, 16 Sep 2003, Samsuri et al. NES 371 (SING); ibidem, 8 Jul 2003, Samsuri et al. NES 80 (SING); MacRitchie, 4 Apr 2001, Tang \& Sidek 1567 (SING).

Notes. In his notes on the Bornean species, $\mathrm{Ng}$ (2005: 233) recognised three varieties, which are all linked by intermediates. These are L. grandis var. grandis, which has leaves that are oblong-elliptic, elliptic or orbicular and are not glaucous below, but have brown indumentum on the twigs and leaf undersurface; Litsea grandis var. paludosa, which has leaves that are ovate or elliptic and glaucous below; and L. grandis var. rufofusca, which has leaves that are ovate, not glaucous below, with a dark blackish red-brown indumentum. Although these differences can also be found in material from Singapore and Peninsular Malaysia, most specimens are intermediates between these three extremes and I therefore do not recognise these varieties. In their treatment of the Thai material, Ngernsaengsaruay et al. (2011: 83), noted variation from north to south in the hairiness of the leaves and in the prominence of the tertiary veins. Although there is much variation in these characters in the Singaporean and Peninsular Malaysian specimens, I could not find any regional variation.

20. Litsea hirsutissima Gamble, Bull. Misc. Inform. Kew: 1910: 357 (1910); Ridley, Fl. Malay Penins. 3: 118 (1924); Burkill \& Henderson, Gard. Bull. Straits Settlem. 3: 416 (1925); Kochummen in Ng, Tree Fl. Malaya 4: 158 (1989); Ngernsaengsaruay et al., Thai Forest Bull., Bot. 39: 85 (2005); Ngernsaengsaruay et al., Thai Forest Bull., Bot. 39: 59 (2011). - TYPE: [Malaysia], Perak, Goping, August 1880, King's Collector 
404 (lectotype K [K000797029], designated by Ngernsaengsaruay et al., Thai Forest Bull., Bot. 39: 85 (2005)).

Tetranthera amara (Blume) Nees var. fuscotomentosa Meisn. in DC., Prodr. 15: 190 (1864), syn. nov. - Litsea amara Blume var. fuscotomentosa (Meisn.) Hook.f., Fl. Brit. India 5: 163 (1887); Ridley, Fl. Malay Penins. 3: 117 (1924). - Litsea umbellata (Lour.) Merr. var. fuscotomentosa (Meisn.) I.M.Turner, Novon 6: 222 (1996). - TYPE: [Malaysia], Penang, Phillips s.n. (lectotype K [no barcode], designated by I.M.Turner, Novon 6: 222 (1996)).

Litsea hirsutissima Gamble var. geniculata Gamble, Bull. Misc. Inform. Kew 1910: 357 (1910); Ridley, Fl. Malay Penins. 3: 118 (1924). - TYPE: [Peninsular Malaysia], Perak, Goping, October 1880, King's Collector 878 (lectotype K [K000797026], designated here; isolectotypes BM [BM000799081], K [K000797027, K000797028]).

Litsea hirsutior Kosterm., Reinwardtia 10: 207 (1985), syn. nov. - TYPE: [Peninsular Malaysia], Kelantan, Sungai Lebir, 28 April 1976, Stone \& Mahmud Sidek 12546 (holotype KLU n.v.; isotype KEP [128571]).

Shrub or tree 1-5(-10) $\mathrm{m}$ tall. Twigs slender, 1.6-4.5 $\mathrm{mm}$ thick, round to angular in cross-section, densely hairy; hairs erect, reddish, rarely reddish brown; terminal leaf bud ovoid, 5-7.7 mm long, velutinous (hairs erect, reddish). Leaves alternate; leaf blade slightly bullate, chartaceous, elliptic to oblanceolate, 7.7-25 × 4-32 cm, apex acute to acuminate, always with a sharp tip, base cuneate to almost rounded, margins sometimes ciliate; secondary veins 9-18 pairs, curving near the margin; tertiary veins scalariform; surface above dark green, glabrous to sparsely hairy (hairs dark red-brown, erect), indumentum usually denser on midrib and secondary veins, midrib and secondary veins sunken, tertiary veins distinct; surface below green, glaucous, sparsely to densely hairy (hairs dark red-brown), indumentum denser on midrib and secondary veins, midrib and secondary veins raised, tertiary veins distinct; petiole 5-25 mm long, slender to swollen, velutinous to densely hairy (hairs erect, reddish). Inflorescences clusters of umbels, $0.6-2.7 \mathrm{~cm}$ long, arranged in axils of leaves or along branchlets; umbels $0.4-0.7 \mathrm{~cm}$ in diameter; bracts 4 , orbicular or broadly ovate, concave, $3.2-5 \times 1.5-3.4 \mathrm{~mm}$, densely to sparsely hairy outside. Flowers white; male flowers 5-6 in each umbel, perianth lobes 6, linear-oblong or oblong, 1.6-3.5 $\times 0.5-1$ $\mathrm{mm}$, apex acute, stamens 7-10, unequal, 1.7-5 mm long, densely hairy, anthers (2-)4 celled, 0.5-1 mm long; female flowers not known. Fruits ovoid or broadly ovoid, $12-14 \times 7-10 \mathrm{~mm}$, apex rounded to acute, smooth, glabrous, glossy, red when mature; cupule papery, shallow, 5-7 $\mathrm{mm}$ in diameter, green, smooth and velutinous, covering only the lower part of the fruit, perianth lobes 1.7-1.9 mm long; stalk swollen and tapering distally, 5-8 $\times 2-2.5 \mathrm{~mm}$, glabrous to sparsely hairy.

Distribution. Peninsular Thailand and Peninsular Malaysia (see Fig. 14). 
Ecology. Growing in forests and sometimes swamps, from 50-900 m altitude. Flowering from April to January; fruiting from February to October.

Vernacular names. Kayu chenak, Medang puteh (Temuan).

Provisional IUCN conservation assessment. This species is known from at least 11-20 localities and has a relatively large extent of occurrence (EOO of 153,348 $\mathrm{km}^{2}$ ) and area of occupancy (AOO of $76 \mathrm{~km}^{2}$ ) and therefore an assessment of globally Least Concern is proposed.

Specimens examined. PENINSULAR MALAYSIA: Kedah: Bukit Enggang, 31 Mar 1930, Symington KEP 24092 (KEP). Perak: Piah F.R., 16 Feb 1935, Jaamat 39287 (KEP); Sungai Kenering, 15 Jun 1930, Henderson SFN 23886 (BM, KEP); Kludaug Saioug, 25 Mar 1931, Symington KEP 25703 (KEP); Goping, Aug 1880, King's Collector 404 (K); Sungei Lipuh, 12 Dec 1920, Haniff 6965 (BM, K); Gunung Hijau, Dec 1887, Curtis 1344 (K); Kluang Tanjung, 25 Mar 1931, Symington KEP 25703 (K). Terengganu: Tasik Kenyir, 5 Apr 2009, Kamarul Hisham FRI 67112 (KEP). Pahang: Lipis, Taman Negara, 7 May 2008, Lim FRI 64814 (KEP); Fraser's Hill, 9 Nov 1937, Medan 45404 (KEP); Sabai estate, near Bentong, 27 Jan 1958, Furtado 174 (K). Selangor: Ulu Langat, 20 Nov 1960, Gadoh anak Umbai KL 2222 (KEP); ibidem, 4 Nov 1960, Gadoh anak Umbai KL 1145 (KEP); ibidem, 30 Nov 1960, Gadoh anak Umbai KL 2248 (KEP); Bukit Lagong, 12 Jan 1979, Suppiah FRI 28250 (KEP). Kuala Lumpur: Weld Hill, 9 Jan 1919, Ahmad 2936 (KEP); ibidem, 24 Nov 1908, Hashim 83 (BM, KEP). Johor: Sungai Kayu, 19 Mar 1937, Henderson SFN 32430 (BM [2 sheets], KEP); Sungai Pelepah, 5 Mar 1928, Nur SFN 20006 (KEP).

Notes. In this species, the outer whorls of stamens are always 4-celled, but in some specimens the inner whorls can be 2- or 3-celled, in which case the upper cells are reduced (see also Gamble's card attached to King's Collector 878 at K).

Litsea hirsutior appears to have been established on the ciliate nature of the leaf margins, the swollen petioles, and the smaller ovate or orbicular leaves. However, the ciliate leaf margins are just a character of young leaves as can be clearly seen in some collections that have both old and young leaves (King's Collector 878), while the swollen petioles and the smaller leaves are part of a continuum within this species.

There is only one gathering mentioned as type material of Litsea hirsutissima var. geniculata (Gamble 1910b: 357): King's Collector 878. The K specimen [K000797026] has the characteristic card with drawings and dissection made by Gamble, and so is designated here as the lectotype.

21. Litsea johorensis Gamble, Bull. Misc. Inform. Kew: 1910: 315 (1910); Gamble, J. Asiat. Soc. Bengal, Pt. 2, Nat. Hist. 75: 133 (1912); Ridley, Fl. Malay Penins. 3: 114 (1924); Henderson, Gard. Bull. Straits Settlem. 4: 312 (1928); Kochummen in Ng, Tree Fl. Malaya 4: 159 (1989); Ngernsaengsaruay et al., Thai Forest Bull., Bot. 39: 60 (2011). - TYPE: [Peninsular Malaysia], Johor, Tanjong Bunga, 1894, Ridley 6458 (lectotype K [K000797051], designated by Ngernsaengsaruay et al., Thai Forest Bull., Bot. 39: 60 (2011)). 
Lepidadenia magnifica Miq., F1. Ned. Ind. 1(1): 936 (1858), syn. nov. - Cylicodaphne magnifica (Miq.) Meisn., DC, Prodr. 15(1): 203 (1864). - Litsea magnifica (Miq.) Fern.Vill., Nov App. 181 (1880), nom. illeg. non Saporta (1865); Ridley, F1. Malay Penins. 3: 115 (1924); Kochummen in Ng, Tree Fl. Malaya 4: 160 (1989). - Litsea magnifica (Miq.) Boerl., Handl. Fl. Ned. Ind. 3: 144 (1900), isonym. - TYPE: [Indonesia], Sumatra, Batang Baroes, Teysmann s.n. (lectotype U [U0002882], designated here).

Litsea trunciflora Gamble, Bull. Misc. Inform. Kew 1910: 316 (1910); Gamble, J. Asiat. Soc. Bengal, Pt. 2, Nat. Hist. 75(1): 135 (1912); Ridley, Fl. Malay Penins. 3: 114 (1924). - TYPE: [Peninsular Malaysia], Perak, Goping, July 1883, King's Collector 4582 (lectotype K [K000797046], first step designated by Ngernsaengsaruay et al., Thai Forest Bull., Bot. 39: 62 (2011), second step designated here; isolectotypes BM [BM000799064], K [K000797047]).

Litsea magnifica (Miq.) Fern.-Vill. var. pahangensis Ridl., Fl. Malay Penins. 3: 115 (1924); Kochummen in Ng, Tree Fl. Malaya 4: 160 (1989). - TYPE: [Peninsular Malaysia], Pahang, Kuala Tenok, August 1891, Ridley s.n. (lectotype SING [SING0252050], designated here).

Tree 2-18 m tall, dbh 1-5 cm; bark smooth, whitish or greyish green or brown, inner bark yellowish brown to orange-brown, sapwood bright to pale yellow or brown. Twigs 4.5-5 mm thick, dark velutinous when young, whitish when older; hairs dark brown, erect, curly; terminal leaf bud ovoid, 6-9 mm long, apex acute, velutinous (hairs dark brown). Leaves spirally arranged, clustered at the ends of the twigs, sometimes with a smell when crushed; leaf blade leathery, obovate or oblanceolate, 10-56 × 4-23 $\mathrm{cm}$; apex acute to rounded, base attenuate, margins straight; secondary veins 10-25 pairs, curving near the margin; tertiary venation scalariform-reticulate; surface above (dark) green, shiny, glabrous except on midrib, midrib and secondary veins sunken, tertiary veins faint to indistinct; surface below shiny, often glaucous, sparsely hairy (hairs erect), rarely glabrous, midrib and secondary veins raised, tertiary veins faint to distinct below; petiole channelled, 15-46 mm long, swollen especially at the base or not, velutinous when young (hairs dark to light brown, erect, curly), glabrous when older. Inflorescences clusters of umbels on reduced branchlets, these borne on the trunk, usually at the base; clusters of umbels 1.5-4 cm long; umbels $1-1.5 \mathrm{~cm}$ in diameter, velutinous; bracts 4, decussate, suborbicular, concave, 6-12 × 5-10 mm, velutinous outside. Flowers cream-coloured; male flowers 6-8 in each umbel, perianth lobes 6, obovate-lanceolate, ovate-oblong or oblong, 3.5-5 $\times 1-1.5 \mathrm{~mm}$, hairy, stamens 9-12, unequal, 2.5-5 mm long, hairy, anthers 2-4 mm long; female flowers 7-8 in each umbel, perianth lobes 6 , obovate-lanceolate, ovate-oblong or oblong, 3.5-5 $\times$ 1-1.5 mm, hairy, ovary ovoid, 1-1.5 × 0.5-1 mm, glabrous, style $2.5-4 \mathrm{~mm}$ long, stigma peltate. Fruits ovoid, 10-15 $\times 7-12 \mathrm{~mm}$, apex pointed, glabrous, glossy, red to dark purple or black when mature; cupule cup-shaped, 7-10 $\times 4-7 \mathrm{~mm}$, velutinous, margins wavy; stalk 0-20 × 1.8-3 mm, not swollen, velutinous. 
Distribution. Peninsular Thailand, Peninsular Malaysia and Borneo (see Fig. 14). In Peninsular Malaysia, found throughout.

Ecology. Growing in lowland to montane forests, sometimes along rivers and in peat swamps, from 0-1200 m altitude. Flowering from February to September; fruiting from April to November.

Provisional IUCN conservation assessment. This species is known from 30-50 localities and has a relatively large extent of occurrence (EOO of 496,765 $\mathrm{km}^{2}$ ) and area of occupancy (AOO of $84 \mathrm{~km}^{2}$ ) and therefore an assessment of globally Least Concern is proposed.

Specimens examined. PENINSULAR MALAYSIA: Perak: Goping, King's Collector 8211 (K); Slim Hills, 4 Sep 1966, Whitmore FRI 795 (KEP). Kelantan: Jeli, 2 May 1967, Ismail KEP 104261 (KEP); Sungai Tekal, 28 Oct 1927, Henderson SFN 19714 (KEP). Terengganu: Sekayu F.R., 22 Sep 1969, Suppiah FRI 11851 (KEP); Dungun, 24 Jul 2009, Lim FRI 65101 (KEP); Sungai Kerbat, 24 Jun 1971, Whitmore FRI 20217 (KEP). Pahang: Jerantut, Taman Negara, 12 May 2008, Lim FRI 64878 (KEP); Labis, 19 Feb 1971, Ahmad \& Shukor SA 524 (KEP); Kuala Teku, 20 Jul 1936, Kiah SFN 31738 (BM); Tembeling, 12 Jul 1929, Henderson SFN 21775 (BM, KEP); Gunung Senyum, Jun 1917, Evans s.n. (BM); Taman Negara, Kuala Tahan, 10 Jun 1971, Whitmore FRI 20131 (KEP). Negeri Sembilan: Pasoh F.R., 15 Apr 2015, Syazwani et al. FRI 81872 (KEP); Pasoh F.R., 14 Apr 2015, Syazwani et al. FRI 81862 (KEP); Pasoh, 13 May 1982, Vethevelu FRI 29698 (KEP); Gunung Angsi, 17 Mar 1971, Sohadi FRI 14601 (KEP). Johor: Mersing, Endau-Rompin, 3 Jul 2012, Kamarul Hisham FRI 73804 (KEP); Gunung Blumut, 22 Jun 1923, Holttum 10613 (BM); Gunung Pulau, 24 Apr 1922, Kiah SFN 7769 (BM); Gunung Arong, 19 Nov 1975, Stevens et al. 88 (KEP); Kluang, 27 Aug 2007, Rosdi FRI 58727 (KEP); Sungai Sedili, 13 Apr 1935, Corner SFN 29282 (KEP); near Castlewood, Ridley 9163 (K); Mount Austen, Ridley 11995 (K); Seduah, Aug 1908, Ridley 13479 (BM, K).

Notes. In the original description of Litsea trunciflora (Gamble 1910a: 316), only one gathering is mentioned: King's Collector 4582. In their treatment of the Thai species, Ngernsaengsaruay et al. (2011: 62) lectotypified the K material of this gathering. However, there are two specimens of this gathering at K [K000797046, K000797047] and the specimen [K000797046] is designated here in a second step lectotypification.

Litsea magnifica was thought to be different from L. johorensis by the latter having a petiole that is swollen at the base (Kochummen, 1989: 160). In this study, I found that many petioles were intermediate between these two extreme forms, sometimes on the same specimen.

In the original description of Litsea magnifica var. pahangensis (Ridley 1924: 115) several unnumbered gatherings are given: Pahang River, Ridley; Tahan River, Ridley; Kuala Tenok, Ridley; Malacca, Cantley and Selangor, Cantley. Of these gatherings, only one specimen by Ridley from Kuala Tenok could be found and is designated here as the lectotype.

There is only one gathering mentioned as type material of Lepidadenia magnifica in Miquel (1855-1858: 936): Sumatra, Batang Baroes, J.E. Teysmann. The $\mathrm{U}$ specimen [U0002882] is designated here as the lectotype. 
22. Litsea lanceolata (Blume) Kosterm., Reinwardtia 7: 348 (1968); Ng, Gard. Bull. Singapore 57: 240 (2005); Keng, Concise Fl. Singapore, vol. 1, Gymn. Dicot. 19 (1990). - Aperula lanceolata Blume, Mus. Bot. 1: 367 (1851). - TYPE: [Indonesia], Java, Blume s.n. (lectotype U [U0002822], designated by De Kok, Gard. Bull. Singapore 69: 174 (2017); isolectotype U [U0002823]).

Litsea sarawacensis Gamble, Bull. Misc. Inform. Kew, 1910: 365 (1910); Ridley, Fl. Malay Penins. 3: 130 (1924); Keng, Concise Fl. Singapore, vol. 1, Gymn. Dicot. 19 (1990). - TYPE: Singapore, Reservoir Woods, July 1893, Ridley 4817 (lectotype K [K000797140], designated by De Kok, Gard. Bull. Singapore 69: 176 (2017); isolectotypes BM [BM001121299], SING [SING0011250]).

Tree or shrub 4-7 m tall, dbh 1-4 cm. Twigs slender, 1.2-2.1 mm thick, round to flattened in cross-section, densely hairy when young, soon becoming sparsely hairy or glabrous; hairs small, appressed, yellowish; terminal leaf bud lanceolate, 1.4-1.7 $\mathrm{mm}$ long, velutinous. Leaves (sub)opposite; leaf blade thinly leathery, elliptic to (ob)lanceolate, $7.5-18 \times 1.9-5 \mathrm{~cm}$, apex acuminate with tip 1-2.7 $\mathrm{mm}$ long, base cuneate, drying reddish brown; secondary veins 5-7 pairs, curving and becoming brochidodromous; tertiary veins scalariform-reticulate; surface above glabrous with a few hairs on the midrib, midrib raised to sunken, secondary veins sunken, tertiary veins visible; surface below glaucous, glabrous except for hairs on the midrib, midrib and secondary veins raised, tertiary veins distinct; petiole half terete to channelled, 4.7-10 mm long, slender, glabrous or sparsely hairy, black and wrinkled when dried. Inflorescences clusters of umbels, 5-10 mm long, in axils of leaves or along branchlets, umbels 3-5 mm in diameter, densely hairy; bracts 4, decussate, suborbicular or broadly ovate, concave, 1.5-2.2 × 1-2 mm, densely hairy. Flowers yellow; male flowers 5-6 in each umbel, perianth lobes 6 , elliptic or elliptic-oblong, $0.6-1.6 \times 0.6-1 \mathrm{~mm}$, hairy, stamens 6-12, unequal, 1.3-1.6 mm long, glabrous to sparsely hairy at base, anthers $0.8-1.3 \mathrm{~mm}$ long; female flowers 3 in each umbel, perianth lobes 6 , elliptic or ellipticoblong, $0.8-1 \times 0.5-1 \mathrm{~mm}$, hairy, ovary ovoid, $0.5-0.6 \mathrm{~mm}$ long, glabrous, style $0.8-1$ mm long, stigma inconspicuous. Fruits ovoid to ellipsoid, 9-13 $\times 4.5-8 \mathrm{~mm}$, apex shortly pointed, glabrous; cupule shallow, c. $3.7 \mathrm{~mm}$ in diameter, velutinous; stalk velutinous.

Distribution. Peninsular Malaysia, Singapore, Sumatra, Borneo and Java (see Fig. 15).

Ecology. Growing in primary and secondary lowland and montane forests, sometimes in swamps or along rivers, in loamy soils, at 0-1500 $\mathrm{m}$ altitude. Flowering from March to November; fruiting from May to September.

Provisional IUCN conservation assessment. This species is known from about 100 localities and has a large extent of occurrence (EOO of 2,005,599 $\mathrm{km}^{2}$ ) and area of occupancy (AOO of $296 \mathrm{~km}^{2}$ ). Because of this, and the fact that it can grow in secondary vegetation, an assessment of globally Least Concern is proposed. 


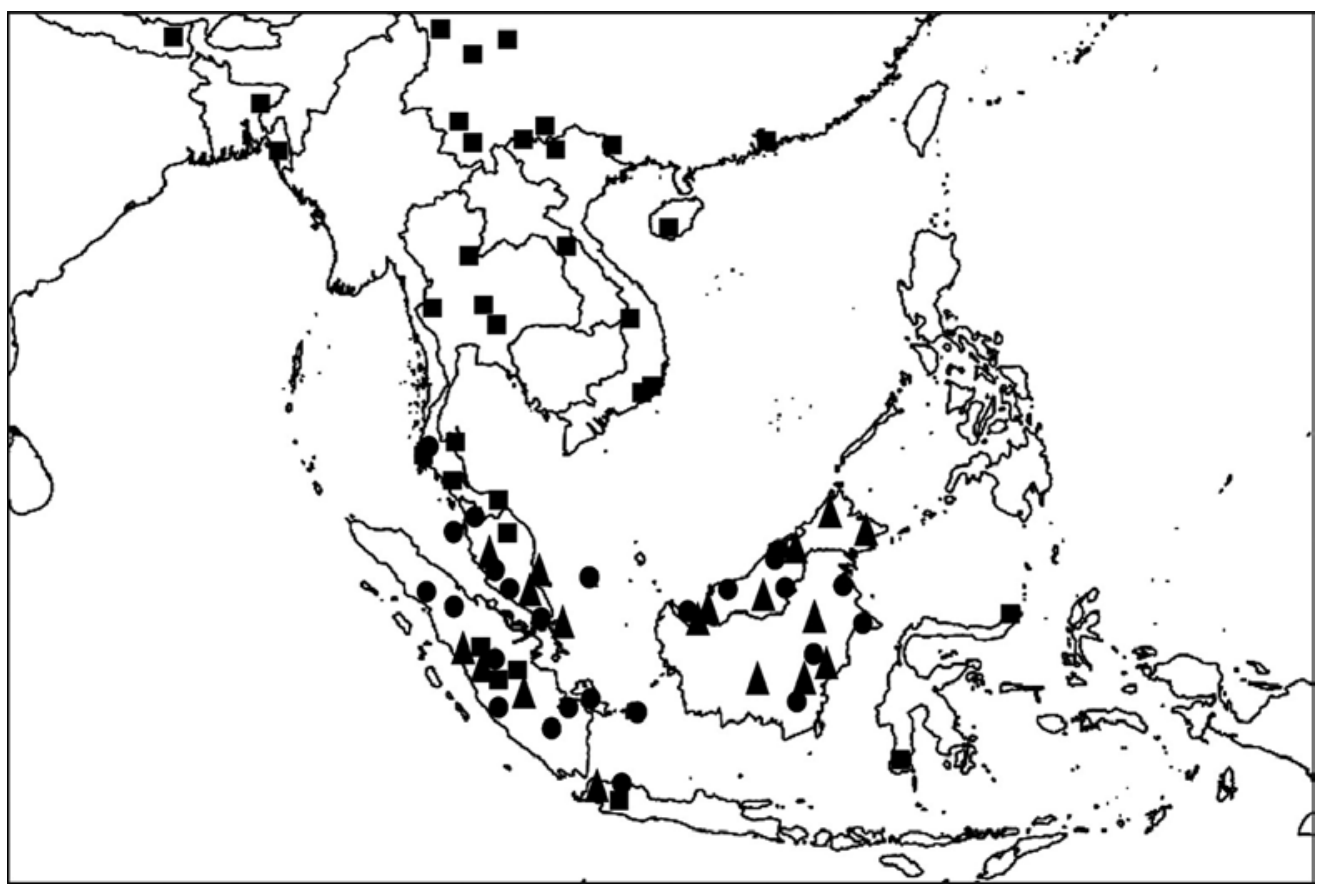

Fig. 15. Distribution of Litsea lanceolata $(\boldsymbol{\Delta})$, Litsea lancifolia $(\boldsymbol{\bullet})$ and L. machilifolia $(\bullet)$.

Specimens examined. PENINSULAR MALAYSIA: Perak: Gunung Hijau, 15 Sep 1949, Sinclair \& Kiah SFN 38743 (BM). Terengganu: Kemaman, Jeram Tanduk, 12 Jun 2014, Chew P1 H23 (KEP). Pahang: Gunung Tapis, Kuantan, 13 Jun 1934, Symington \& Kiah SFN 28815 (K, KEP, SING); ibidem, 28 Sep 1971, Chan FRI 17697 (KEP); Kuantan, 14 Apr 1931, Soh 15133 (K, KEP, SING); Labis F.R., 4 Apr 1972, Kochummen FRI 16487 (KEP); Baloh Kuantan, 18 Apr 1921, Mahamud FMS 3721. Selangor: Ulu Gombak, 2 Nov 1921, Hume 9443 (SING); Gunung Bunga Bua, 29 May 1966, Ng FRI 1146 (K, KEP). Johor: Sungai Kayu, 11 Apr 1936, Corner SFN 30855 (BM, K, KEP, SING [3 sheets]); Gunung Panti West, 14 Apr 1936, Corner SFN 30856 (KEP, SING [2 sheets]).

SINGAPORE: Reservoir Woods, Jul 1893, Ridley 4817 (BM, K, SING).

Notes. In his notes on the Bornean species, Ng (2005) synonymised Lindera subumbelliflora (Blume) Kosterm. with this species. This led to a widespread species, Litsea subumbelliflora (Blume) $\mathrm{Ng}$, that had either 2 or 4 anther-locules and 1-6 flowers per umbel. This merger had the effect of blurring the morphological distinctions between the genera Litsea, Lindera and Iteadaphne (see introduction) within a single species. In this present account the traditional circumscription of Litsea lanceolata is preferred pending more detailed research using DNA sequence data to test generic delimitation before we can recircumscribe these genera.

23. Litsea lancifolia (Roxb. ex Nees) Fern.-Vill. in Blanco, Fl. Filip., ed. 3: 181 (1880); Lecomte, Nouv. Arch. Mus. Hist. Nat., ser. 5, 5: 90 (1913); Lecomte, Fl. Indo-Chine 
5: 134 (1914); Ridley, Fl. Malay Penins. 3: 130 (1924); Liou Ho, Laurac. Chine \& Indochine 198 (1932); Allen, Ann. Missouri Bot. Gard. 25: 395 (1938); Kochummen in Ng, Tree Fl. Malaya 4: 160 (1989); Keng, Concise Fl. Singapore, vol. 1, Gymn. Dicot. 19 (1990); Ng, Gard. Bull. Singapore 57: 234 (2005); Ngernsaengsaruay et al., Thai Forest Bull., Bot. 39: 68 (2011). - Tetranthera lancifolia Roxb. ex Nees in Wallich, P1. Asiat. Rar. 2: 65 (1831). - TYPE: [Bangladesh], Sylhet, 1821, Wallich s.n. [EIC 2532] (lectotype K-W [K001116369], first step designated by Ngernsaengsaruay et al., Thai Forest Bull., Bot. 39: 68 (2011), second step designated here; isolectotypes BM [BM000951038], E [E00393197, E00393199, E00393200], GH [GH00041772], GZU [GZU000254496, GZU000254497], K [K000357527], K-W [K001116368], MEL [MEL2388443], NY [NY00355982], PH [PH00030197], U [U0002824]). (Fig. 16).

Litsea lancifolia (Roxb. ex Nees) Fern.-Vill. var. rufa Ridl., Fl. Malay Penins. 3: 130 (1924). - TYPE: [Peninsular Malaysia], Perak, Ulu Budong, 1884, Kunstler 10113 (lectotype K [K000797139], designated here).

Litsea hansenii Kosterm., Nat. Hist. Bull. Siam Soc. 25: 37 (1975); Ngernsaengsaruay et al. Thai Forest Bull., Bot. 39: 68 (2011). - TYPE: Thailand, Tak, Doi Pae Poe, 14 March 1968, Hansen \& Smitinand 12916 (holotype C [C10013620]).

Tree or shrub 2-12 m tall, dbh 4-20 cm; bark smooth, greyish brown or dark brown. Twigs slender, 1.3-2 mm thick, rounded in cross-section, densely hairy when young; hairs erect, short, yellowish; terminal leaf bud 2.2-5.5 $\mathrm{mm}$ long, lanceolate to ovate, apex acute, velutinous. Leaves (sub)opposite; leaf blade blade thinly leathery, elliptic to (ob)lanceolate, 5-23.5 $\times 1.8-7 \mathrm{~cm}$, apex acute to shortly acuminate, sometimes with a long tip, base cuneate, drying greenish brown; secondary veins 5-13 pairs, obscurely brochidodromous; tertiary veins scalariform-reticulate or reticulate; surface above dark green, glabrous, but densely hairy on midrib and secondary veins, midrib and secondary veins shallowly sunken or flattened, tertiary veins visible; surface below green, glaucous, sparsely hairy on intervenium and densely hairy on veins, midrib and secondary veins raised beneath, tertiary veins distinct; petiole 2-15 mm long, glabrous to densely hairy, dark and wrinkled when dried. Inflorescences clusters of umbels, $0.5-1 \mathrm{~cm}$ long, in axils of leaves or along branchlets; umbels 3-6 $\mathrm{mm}$ in diameter, sparsely to densely hairy; bracts 4, decussate, suborbicular or broadly ovate, concave, 2-4.5 $\times 2-3 \mathrm{~mm}$, densely hairy outside, green. Flowers cream or yellowish to orange, sweet-smelling; male flowers 3-5 in each umbel, perianth lobes 6 , ellipticoblong or oblong, 1.4-2.5 × 0.5-1 mm, hairy, stamens 7-9, unequal, 1-2 mm long, with a few hairs present, anthers $0.5-1 \mathrm{~mm}$ long; female flowers $3-5$ in each umbel, perianth lobes 6 , elliptic, elliptic-oblong, $1.5-2 \times 0.5-0.8 \mathrm{~mm}$, hairy, ovary ovoid, 0.8-1.5 × 0.5-0.8 mm, glabrous, style 1-1.5 mm long, stigma peltate. Fruits globose to ellipsoid, 4-15 $\times 4-9.5 \mathrm{~mm}$, apex rounded, glabrous, dark purple or black when mature, glossy; cupule shallow, $2.7-3.2 \mathrm{~mm}$ in diameter, densely to sparsely hairy; stalk $0-1.6 \mathrm{~cm}$ long, densely hairy. 


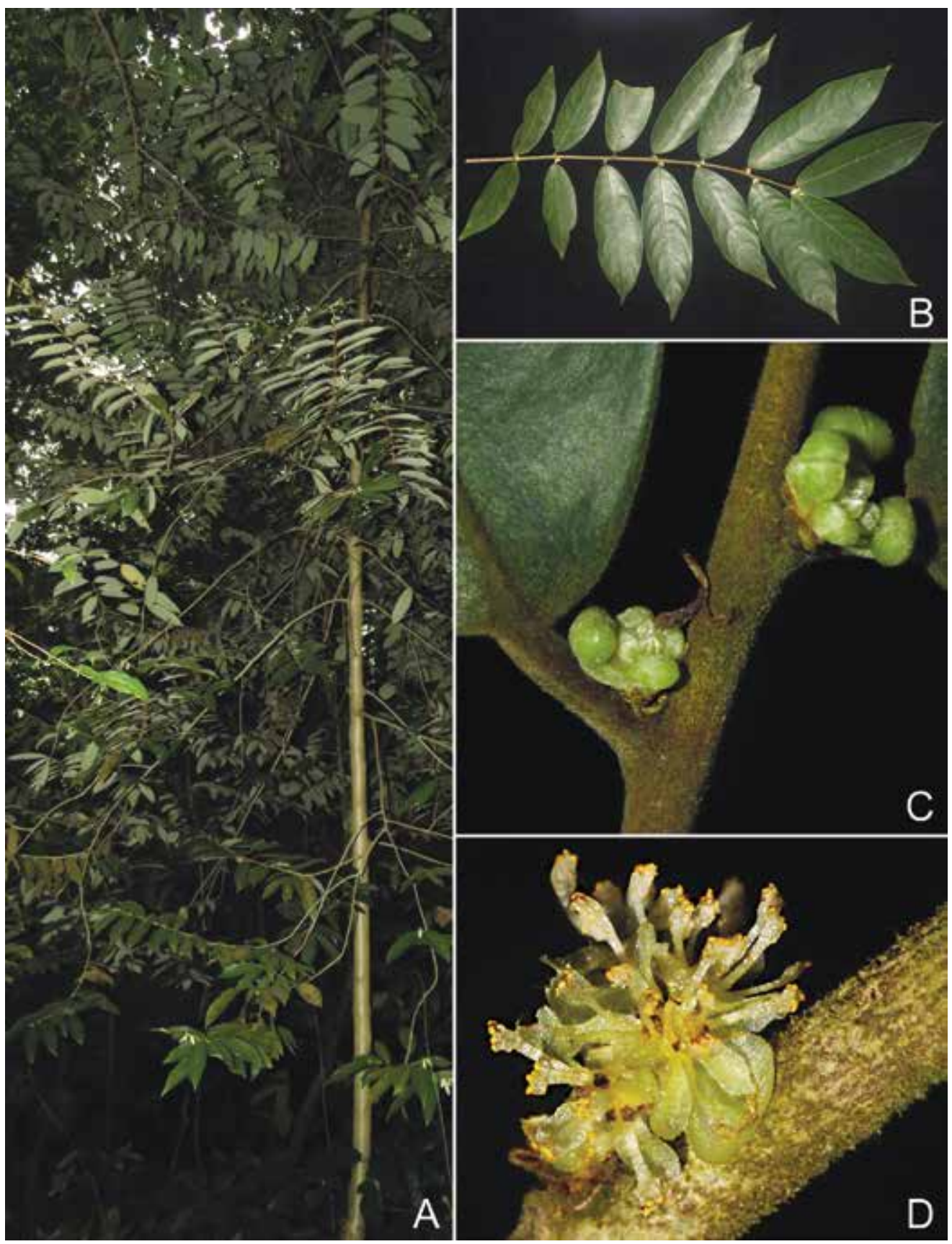

Fig. 16. Litsea lancifolia (Roxb. ex Nees) Fern.-Vill. A. Habit. B. A leafy branch. C. Flower buds at axils. D. Flower, showing anther flaps. From Singapore, MacRitchie Nature Trail; A-C from Ng \& Lim SING2018-226; D from Lim et al. SING2018-397. (Photos: A \& C, R.C.J. Lim; B \& D, X.Y. Ng). 
Distribution. India, Bangladesh, Nepal, China, Myanmar, Thailand, Laos, Vietnam, Peninsular Malaysia, Singapore, Sumatra, Borneo, Java and Sulawesi (see Fig. 15).

Ecology. Growing in lowland and lower montane forests, at 0-250 m altitude (up to $1700 \mathrm{~m}$ in Thailand), sometimes over granite. Flowering from March to September; fruiting from May to September.

Vernacular names. Narrow-leaved medang (Singapore); Medang kijoo, Medang melukot, Medang rengau (Malay).

Provisional IUCN conservation assessment. This species is known from about 200 localities and has a very large extent of occurrence (EOO of 10,369,647 $\mathrm{km}^{2}$ ) and area of occupancy (AOO of $508 \mathrm{~km}^{2}$ ) and therefore an assessment of globally Least Concern is proposed.

Specimens examined. PENINSULAR MALAYSIA: Kedah: Ulu Sungai Charok, 19 Mar 1938, Sow 46169 (KEP); Kokmoi F.R., 18 Aug 1938, Awang 47851 (KEP). Perak: Pulau Tanjung, Jul 1888, Wray 2610 (SING); Larut, Aug 1882, King's Collector 3233 (SING [2 sheets]); ibidem, Aug 1882, King's Collector 3284 (BM); ibidem, Sep 1882, King's Collector 3351 (BM); ibidem, Sep 1884, King's Collector 6609 (SING [2 sheets]); Ulu Buboug, Jul 1886, King's Collector 10533 (BM); Batang Padang, Jul 1885, Kunstler 7789 (K [2 sheets]); Gunung Bubu F.R., 31 Oct 1958, Sinclair 9903 (SING); Taiping, Pondok Tanjung, 25 Jul 1916, Geoh 1144 (KEP, SING); Pondok Tanjong, 12 Apr 1918, Cubilt FMS 2204 (KEP); Parit F.R., 8 Apr 1935, Symington KEP 39494 (KEP, SING); Grik, 11 Mar 1926, Hamid 11014 (KEP, SING); Gunung Hijau, 15 Sep 1949, Sinclair \& Kiah SFN 38743 (SING); Jeram Berua above Kuala Tiang, 24 Jan 1971, Whitmore FRI 15735 (KEP). Kelantan: Sungai Lebir, 13 Sep 1967, Whitmore FRI 4360 (KEP); Sungai Realai F.R., 9 Jul 1987, Damanhuri \& Khairuddin FRI 36996 (KEP). Terengganu: Hutan Simpan Tembat, Ulu Terengganu, 9 Mar 2006, Teo \& Din KL 5208 (KEP); Gunung Padang, Ulu Brang, 16 Sep 1969, Whitmore FRI 12603 (KEP). Pahang: Batok Reserve, Kuantan, 26 Mar 1920, Geop 871 (KEP, SING); Kuantan, 18 Apr 1921, Mohamed 3701 (SING); Lesong F.R., 16 Feb 1971, Suppiah FRI 11897 (KEP); Gua Luas Kuala Keniyas, 4 Mar 1968, Mhd Shah MS 1544 (KEP); Tekam F.R., 25 Jun 1972, Ng FRI 20753 (KEP); Sungai Bertram, 2 Jun 1971, Whitmore FRI 20093 (KEP); Jalan Kulam Ayer, 27 Dec 1929, Kalong 20472 (KEP). Selangor: Sungai Buloh, 22 Dec 1923, Nir SFN 11882 (KEP). Kuala Lumpur: Feb 1890, Curtis 2401 (SING [2 sheets]); Weld Hill, 13 Apr 1918, Hamid 1586 (KEP, SING); ibidem, 3 Mar 1915, Ridley s.n. (BM). Negeri Sembilan: Sungai Menyala F.R., 23 Apr 1975, Kochummen FRI 23101 (KEP). Johor: Sungai Kayu, 14 Mar 1937, Kiah SFN 32394 (SING).

SINGAPORE: Bukit Panjang, 27 May 1906, Ridley 12563 (BM, K, SING); Seletar, 1894, Ridley 6454 (SING); ibidem, 14 Apr 1993, Tan et al. NRS 1498 (KEP, SING); Seletar Reservoir, 27 May 2011, Lua SING2011-218 (SING); MacRitchie, 29 May 2014, Chew SING2014-213 (SING); MacRitchie Nature Trail, 7 Mar 2018, Ng \& Lim SING2018-226 (SING); ibidem, 11 Apr 2018, Lim et al. SING2018-397 (SING); Nee Soon, 19 Mar 1982, Maxwell 82-78 (SING); Mandai, 3 Mar 2009, Leong et al. SING2009-247 (SING).

Notes. In Ng (2005), the Bornean populations were divided into four varieties, which are all linked by intermediates. The varieties were distinguished as follows: 1) Litsea 
lancifolia var. lancifolia: leaves broad, longer than $8 \mathrm{~cm}$, and with the midrib sunken above; 2) Litsea lancifolia var. iliaspaiei $\mathrm{Ng}$ : leaves broad and short ( $<8 \mathrm{~cm}$ long); 3) Litsea lancifolia var. grandifolia (Stapf) $\mathrm{Ng}$ : leaves broad, longer than $8 \mathrm{~cm}$ and with the midrib raised above; and 4) Litsea lancifolia var. rheophytica (Kosterm.) Ng: leaves linear, resembling those of some willows (Salix spp.). Of this morphological variation, only that of the type variety is present in Singapore and Peninsular Malaysia. Further study of the species in Borneo is necessary to determine if the varieties should continue to be recognised.

In the original description of Tetranthera lancifolia Roxb. ex Nees (Wallich, 1831: 65) only one gathering was mentioned: 'Wallich Cat. $n$. 2532', which is specimen 2532 in the East India Company Herbarium, now in Kew. In their treatment of the species of Thailand, Ngernsaengsaruay et al. (2011: 68) lectotypified this name using the specimen in the $\mathrm{K}-\mathrm{W}$ herbarium. However, there are two sheets of this gathering in K-W [K001116368, K001116369]. The one with the original label [K001116369] is designated here in a second step lectotypification.

In the original description of Litsea lancifolia var. rufa (Ridley, 1924: 130) two gatherings were mentioned: Kunstler 7789 and 10113. Specimens of these collections are morphologically very similar and the K specimen [K000797139] of Kunstler 10113 is designated here as the lectotype as it has the most fruits.

24. Litsea machilifolia Gamble, Bull. Misc. Inform. Kew 1910: 320 (1910); Ridley, Fl. Malay Penins. 3: 126 (1924); Kochummen in Ng, Tree Fl. Malaya 4: 160 (1989); Keng, Concise Fl. Singapore, vol. 1, Gymn. Dicot. 19 (1990); Ng, Gard. Bull. Singapore 57: 234 (2005); Ngernsaengsaruay et al., Thai Forest Bull., Bot. 39: 70 (2011). - TYPE: [Peninsular Malaysia], Penang, Moniot Road, June 1886, Curtis 795 (lectotype SING [SING0068773]), first step designated by Ng, Gard. Bull. Singapore 57: 234 (2005), second step designated by De Kok, Gard. Bull. Singapore 69: 174 (2017). (Fig. 17).

Litsea teysmannii Gamble, Bull. Misc. Inform. Kew 1910: 319 (1910); Ridley, Fl. Malay Penins. 3: 126 (1924); Ng, Gard. Bull. Singapore 57: 234 (2005). - TYPE: [Peninsular Malaysia], Malacca, Merilau, 8 June 1886, Ridley 5845 (lectotype SING [SING0093594], designated by Ng, Gard. Bull. Singapore 57: 234 (2005)).

Litsea machilifolia Gamble var. angustifolia Gamble, J. Asiat. Soc. Bengal, Pt. 2, Nat. Hist. 75: 172 (1912); Ridley, Fl. Malay Penins. 3: 126 (1924). - TYPE: [Peninsular Malaysia], Perak, Larut, November 1884, King's Collector 6815 (lectotype K [no barcode], designated by De Kok, Gard. Bull. Singapore 69: 175 (2017); isolectotypes SING [SING0229214, SING0229215]).

Litsea machilifolia Gamble var. montana Ridl., Fl. Malay Penins. 3: 127 (1924); Turner, Gard. Bull. Singapore 64: 232 (2012). - TYPE: [Peninsular Malaysia], Pahang, Bukit Fraser, 16-30 September 1922, Burkill \& Holttum F.M.S. 7784 (lectotype K [K000797064], designated here). 
Litsea panamanja auct. non (Buch.-Ham. ex Nees) Hook.f.: Ridley, J. Straits Branch Roy. Asiat. Soc. 33: 131 (1900), as 'panamonja'; Gamble, J. Asiat. Soc. Bengal, Pt. 2, Nat. Hist. 75(2): 172 (1912); Ridley, Fl. Malay Penins. 3: 127 (1924); Kochummen in Ng, Tree Fl. Malaya 4: 162 (1989); Ng, Gard. Bull. Singapore 57: 234 (2005).

Tree or shrub 7-30 m tall, dbh 10-70 cm; bark smooth to pustulate, white or grey to brown, rarely reddish brown, inner bark pinkish to reddish or pale yellow, sapwood yellowish, aromatic. Twigs slender, 2.6-4 mm thick, rounded to slightly angled in cross-section, glabrous to sparsely hairy, drying dark brown to blackish; terminal leaf bud $6.5-8 \mathrm{~mm}$ long, linear, apex acute, glabrous. Leaves alternate; leaf blade thinly coriaceous or leathery, lanceolate or ovate-lanceolate, 9-22 × 1.7-7 cm, apex acuminate, with a tip 10-20 mm long, base cuneate; secondary veins 8-14 pairs, brochidodromous; tertiary veins reticulate; surface above shiny, dark green, glabrous, midrib raised, secondary veins raised to flattened, tertiary veins obscure; surface below glaucous, pale green, glabrous, midrib and secondary veins raised, tertiary veins distinct; petiole half-terete to channelled in cross-section, 10-20 mm long, glabrous to sparsely hairy, drying black. Inflorescences with the appearance of a raceme of umbels, $2.5-10 \mathrm{~cm}$ long, in the axils of leaves or terminal, along branchlets or at apex of branchlets; umbels $0.5-0.7 \mathrm{~cm}$ in diameter, sparsely hairy to glabrous; bracts 4, decussate, suborbicular or broadly ovate, concave, 3-5 × 3-4 mm, sparsely hairy outside; infructescence with 1-3 fruits. Flowers pale yellow to yellowish green; male flowers 5-6 in each umbel, perianth lobes 6 , elliptic or elliptic-oblong, 1.7-3 $\times 0.8-1$ $\mathrm{mm}$, glabrous, stamens 9-12, unequal, 2.5-6 mm long, glabrous, anthers $1-1.5 \mathrm{~mm}$ long; female flowers 5 in each umbel, perianth lobes 6 , elliptic or elliptic-oblong, $0.5-0.8 \times 1.5-2 \mathrm{~mm}$, glabrous, ovary globose, $0.8-1 \mathrm{~mm}$ in diameter, glabrous, style 1.5-2 mm long, stigma peltate. Fruits globose, 10-26 $\mathrm{mm}$ in diameter, smooth to rugose, glabrous, black or (dark) purple when mature; cupule shallow, 9.5-20 mm in diameter, patent, fleshy, glabrous, margins entire, (bright) orange when mature; stalk 2-25 × 3-6 mm thick, swollen, sparsely hairy, orange-brown.

Distribution. Peninsular Thailand, Peninsular Malaysia, Singapore, Sumatra, Borneo and Java (see Fig. 15).

Ecology. Growing in primary and secondary lowland and hill forests, sometimes in peat swamps, at 30-1500 m altitude. Flowering from August to May; fruiting from July to January.

Vernacular names. Medang keladi, Bunyah medang kulod (Malay).

Provisional IUCN conservation assessment. This species is known from about 50-60 localities and has a large extent of occurrence (EOO of 2,460,500 $\mathrm{km}^{2}$ ) and area of occupancy (AOO of $184 \mathrm{~km}^{2}$ ). Given this distribution and evidence that it can grow in secondary vegetation, an assessment of globally Least Concern is proposed. 


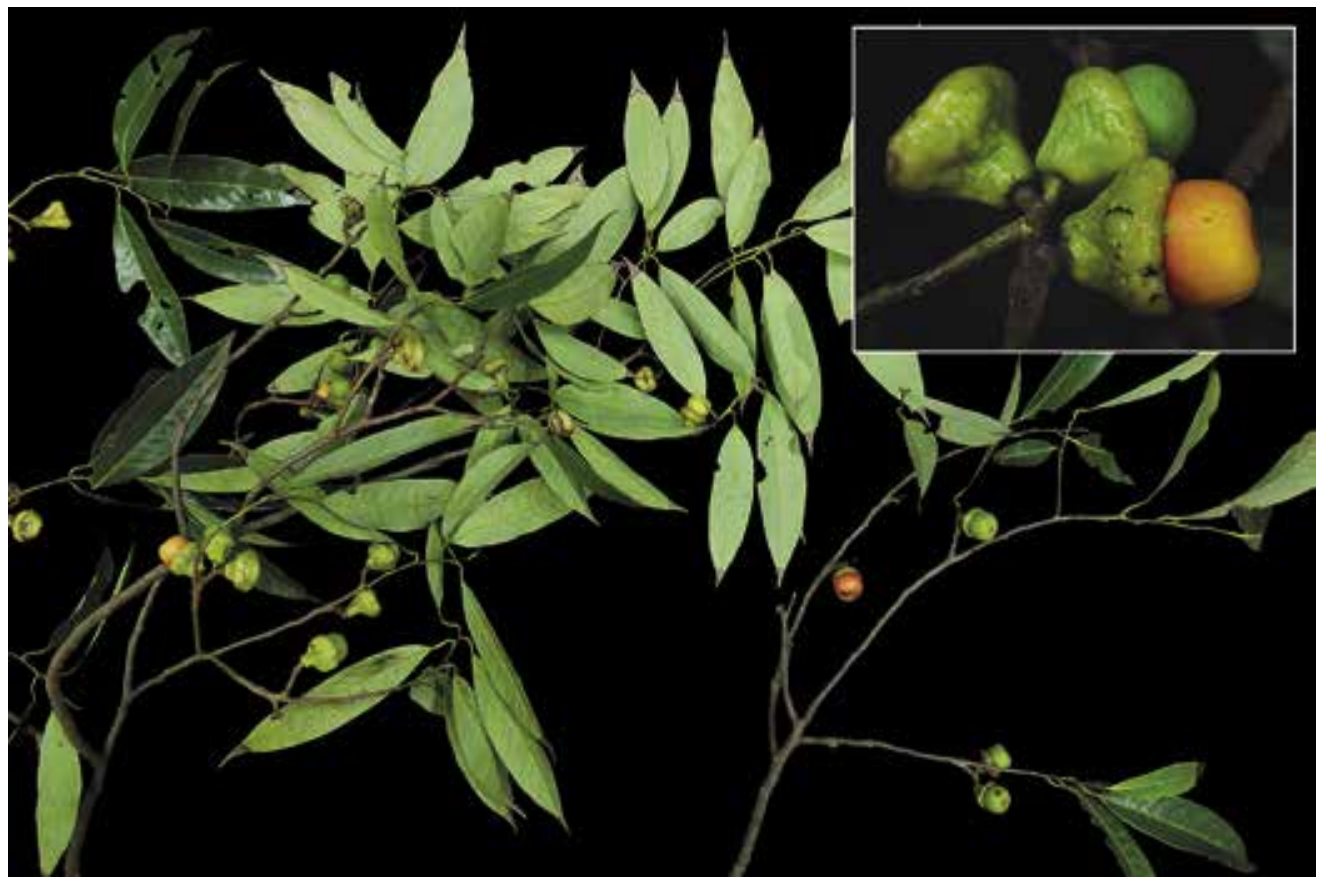

Fig. 17. A leafy branch of Litsea machilifolia Gamble bearing fruits. Inset: Close up of fruits. From Singapore, Bukit Timah Nature Reserve, Teo SING2018-331. (Photos: P.K.F. Leong).

Specimens examined. PENINSULAR MALAYSIA: Kedah: Bukit Enggang, 27 Nov 1969, Everett FRI 13736 (K, KEP). Penang: s.1., Apr 1886, Curtis s.n. (K); Moniot Road, Apr 1886, Curtis 795 (SING [2 sheets]); ibidem, Jul 1886, Curtis 795 (K, SING). Perak: s.l., Scortechini s.n. (K, SING [2 sheets]); Kota, 1888, Wray 2409 (K); Gunong Batu Pateh, 1887, Wray 416 (BM [2 sheets], K); ibidem, lower camp, Wray 985 (K [2 sheets]); ibidem, Wray 1032 (K [2 sheets], SING [2 sheets]); ibidem, Wray 1108 (K); Gunong Haram, Scortechini 328 (K); ibidem, Scortechini 588 (K [2 sheets]); Larut, Nov 1882, Kunstler 3561 (K [2 sheets]); ibidem, Goping, May 1884, King's Collector 6113 (K [2 sheets], SING [2 sheets]). Kelantan: Sungai Terang, 9 Oct 1992, Karim \& Mhd Shah NK 90 (SING). Pahang: Kuantan, Lepar F.R., 20 Aug 1919, Gusoh 818 (K, KEP, SING); Fraser's Hill, 16-30 Sep 1922, Burkill \& Holttum 7784 (SING); ibidem, 16-30 Sep 1922, Burkill \& Holttum 8667 (BM, K, SING); ibidem, 16-30 Sep 1922, Burkill \& Holttum 8809 (BM, K, KEP, SING [2 sheets]); ibidem, 13 Jun 1930, Kaloug 22414 (K, KEP, SING); ibidem, 10 Feb 1931, Syed Alli 22575 (KEP, SING); ibidem, 15 Aug 1937, Corner SFN 33209 (K, KEP, SING); ibidem, Jeriau Road, 20 Aug 1960, Burkill et al. HMB 2424 (K, KEP, SING [2 sheets]); ibidem 8 Jul 1966, Kochummen FRI 2045 (K, KEP); ibidem, 7 Aug 1966, Stone 6482 (K); ibidem, 26 Aug 1981, Kochummen FRI 29361 (K, KEP); ibidem, 11 Oct 1979, Kochummen FRI 11469 (K, KEP); ibidem, 19 Jan 1983, Kochummen FRI 26066 (K, KEP); ibidem, 31 Aug 1923, Henderson 11511 (SING); ibidem, Sungai Yeh, 29 Aug 1923, Nur SFN 11140 (SING); ibidem, 2 Sep 1923, Nur SFN 11216 (KEP, SING); Bukit Goh, 29 Jun 1920, Mohamed FMS 898 (KEP, SING). Selangor: Klang, Telok Forest, 22 Sep 1898, Burkill 3137 (K, KEP); ibidem, 9 Nov 1953, Sinclair SFN 40109 (K, KEP); ibidem, 17 Feb 1966, Kochummen KEP 98558 (K); Genting Simpah Road, 19 Mar 1966, Kochummen 97798 (K, KEP, SING); Bukit Kuda, Jun 1894, Ridley 7623 (BM, K); Gunong Bunga Buah, 28 May 1966, Ng FRI 1128 (K, KEP, SING); Ulu Selangor, Kwang, 10 May 1933, Anonymous KEP 
24879 (K, KEP); Fraser's Hill, 20 Jul 1930, Mahmood 22521 (KEP, SING); ibidem, 24 Jun 1970, Whitmore FRI 15180 (KEP, SING); Rantan Panjang Reserve, 10 Jun 1927, Strugnell 12774 (KEP, SING); Batang Berjunlai, 31 May 1921, Hume 7510 (SING); Ulu Gombak, 13 Sep 1960, Yong KEP 85242 (KEP, SING); Bukit Kutu, Jun 189?, Ridley 7633 (SING). Negri Sembilan: Taupin Hill, 21 Aug 1916, Ridley 2178 (BM, K); Gunong Angsi, near Bugalor, 23 Nov 1923, Nur SFN 11659 (K). Malacca: Merlinau, 16 Apr 1886, Alvins s.n. (SING); Berisu, Jun 1890, Derry 653 (K, SING). Johor: Bukit Paloh estate, 11 Nov 1958, Mhd Shah \& Kadim 369 (K); ibidem, 7 Apr 1958, Mhd Shah \& Kadim 413 (K, SING); Pulau Tioman, 6 May 1927, Nur SFN 18862 (K [2 sheets]).

SINGAPORE: Garden Jungle, 1892, Ridley 4706 (BM, K, SING); ibidem, 1891, Ridley 3458 (BM, K, SING); Bukit Timah Nature Reserve, Jalan Senapang, 26 Aug 1969, Noor MN 449 (SING); Bukit Timah F.R., 19 Aug 1953, Sinclair SFN 39990 (K, SING); Bukit Timah Nature Reserve, Rengas Path, 27 Mar 2018, Teo SING2018-331 (SING); Skimping, Aug 1888, Wray 3019 (K [3 sheets]); ibidem, 27 Mar 1962, Mhd Amin 1 (SING); Bukit Mandai, Jan 1881, Ridley 6739 (SING); ibidem, Jan 1881, King's Collector 1236 (BM, K).

Notes. This widespread and common species can be distinguished by its glabrous leaves that have a long tip at the apex, its inflorescences which resemble racemes of umbels, and by its large fruits. The cupule is reported to be fleshy with a stalk of variable length (0-3 cm long). This variation occurs because the flowering stalk continues to grow during the development of the fruit. Consequently, the length of the fruiting stalk depends on when in this ripening process the specimen was collected. This variation has been a source of great confusion with Gamble (1910a) placing plants with long stalks in Litsea machilifolia and those without a stalk in L. teysmannii. Kochummen (1989) recognised Litsea teysmannii but associated it with growing in swamps. Among those specimens which were not found in swamp, he placed those with a long stalk (2-3 cm long) in Litsea machilifolia, those with a short stalk $(0.7 \mathrm{~cm}$ long) in his Litsea sp. 2, and those without a stalk in Litsea sp. 1. I could not find any other morphological or ecological differences between these groups and found that the variation in length of the fruiting stalk is continuous in nature. I therefore agree with $\mathrm{Ng}$ (2005: 238) and have placed all these groups in one species.

In the original description of Litsea machilifolia var. montana (Ridley, 1924: 127) only one gathering was mentioned: Burkill \& Holttum F.M.S. 7784. The K specimen [K000797139] is designated here as the lectotype.

25. Litsea maingayi Hook.f., F1. Brit. India 5: 175 (1886); Ridley, Fl. Malay Penins. 3: 128 (1924); Kochummen in Ng, Tree Fl. Malaya 4: 161 (1989). - TYPE: [Peninsular Malaysia], Malacca, Maingay s.n. [Kew distribution no. 1273] (lectotype K [K000797147], designated here; isolectotypes K [no barcode], L [L0036744]).

Litsea foxiana Gamble, Bull. Misc. Inform. Kew 1910: 361 (1910), syn. nov.; Ridley, Fl. Malay Penins. 3: 123 (1924); Kochummen in Ng, Tree Fl. Malaya 4: 157 (1989). - TYPE: [Peninsular Malaysia], Penang, Moniot Road, April 1890, Curtis 2305 (holotype K [K000797078]). 
Tree 12-34 m tall, dbh 30-60 cm, trunk slightly fluted, without or with short buttresses; bark smooth to slightly scaly, grey-brown, inner bark (pale) brown, sapwood white to yellowish, vessels visible in slash. Twigs slender to stout, 3.5-7.5 mm thick, dark brown, angular to round in cross-section, glabrous when young; terminal leaf bud 5-9 mm long, lanceolate, apex acute, velutinous. Leaves alternate; leaf blade leathery, elliptic to oblanceolate, $10-32 \times 3.5-9 \mathrm{~cm}$, apex acuminate with a distinct tip, base cuneate; secondary veins $8-16$ pairs, brochidodromous; tertiary veins scalariform; surface above glabrous, midrib raised to flattened, secondary veins sunken, tertiary veins indistinct; surface below glaucous, glabrous, midrib and secondary veins raised, tertiary veins distinct; petiole half-terete, $24-37 \mathrm{~mm}$ long, glabrous, slender. Inflorescences with the appearance of racemes of umbels, $0.6-2 \mathrm{~cm}$ long, sparsely hairy, along branchlets below the leaves; umbels $9-10 \mathrm{~mm}$ in diameter, velutinous; bracts 4 , decussate, suborbicular, concave, $4.6-4.8 \times 3.5-4.5 \mathrm{~mm}$, velutinous outside, glabrous inside, green; infructescence with 1-3 fruits. Flowers yellow; male flowers 5-6 in each umbel, perianth lobes 6 , oblong, $2-3 \times 0.8-1.2 \mathrm{~mm}$, apex acute, velutinous, stamens 9-12, unequal, 2-3 mm long, glabrous, anthers 1-1.3 mm long; female flowers c. 6 in each umbel, perianth lobes 6 , oblong, 1.4-2.5 $\times 0.7-1.3 \mathrm{~mm}$, apex acute, densely hairy, ovary ovoid, $0.8-1.6 \mathrm{~mm}$ in diameter, glabrous, style $1.8-2 \mathrm{~mm}$ long, stigma peltate. Fruits ellipsoid, 20-32 $\times 13-20 \mathrm{~mm}$, smooth, glabrous; cupule cup-shaped, 15-24 × 13-21 mm high, enclosing lower half of fruits, margins slightly wavy, dark brown; stalk 5-15 × 2.5-6 mm, swollen.

Distribution. Peninsular Malaysia and Sumatra (see Fig. 18).

Ecology. Growing in primary and secondary lowland and hill forests, sometimes near streams, at 66-400 m altitude. Flowering from April to November; fruiting from February to April.

Provisional IUCN conservation assessment. This species is known from about 11-15 localities and has a relatively large extent of occurrence (EOO of 191,235 $\mathrm{km}^{2}$ ) and area of occupancy (AOO of $52 \mathrm{~km}^{2}$ ). Given the large extent of occurrence and the number of known localities, and the fact that it can grow in secondary vegetation, an assessment of globally Least Concern is proposed.

Specimens examined. PENINSULAR MALAYSIA: Perak: Larut, Aug 1883, King's Collector 4737 (K [3 sheets]); Gunung Bubu, 29 Feb 1970, Suppiah FRI 11740 (KEP); Kledang Saiong, 8 Apr 1931, Symington KEP 25472 (KEP); Kledang Saiong F.R., 23 Feb 1982, Kochummen FRI 29448 (K, KEP); Slim Hills F.R., 6 Oct 1966, Whitmore FRI 803 (KEP); Slim River, Gunung Besout F.R., 29 Nov 1966, Ng FRI 1774 (KEP). Pahang: Bukit Beserak, 21 Sep 1919, Mahamud 822 (KEP). Selangor: Klang F.R., 16 Oct 1930, Jappar 21973 (K, KEP); ibidem, 16 Oct 1930, Anonymous 21973 (KEP). Johor: Labis, 13 Apr 1967, Suppiah FRI 104955 (K, KEP); Mersing, 28 Oct 1957, Anonymous KEP 77934 (KEP).

Notes. In the original description of Litsea maingayi (Hooker, 1886: 175) two different gatherings from Malacca where mentioned: Maingay s.n. [Kew distribution no. 1264 


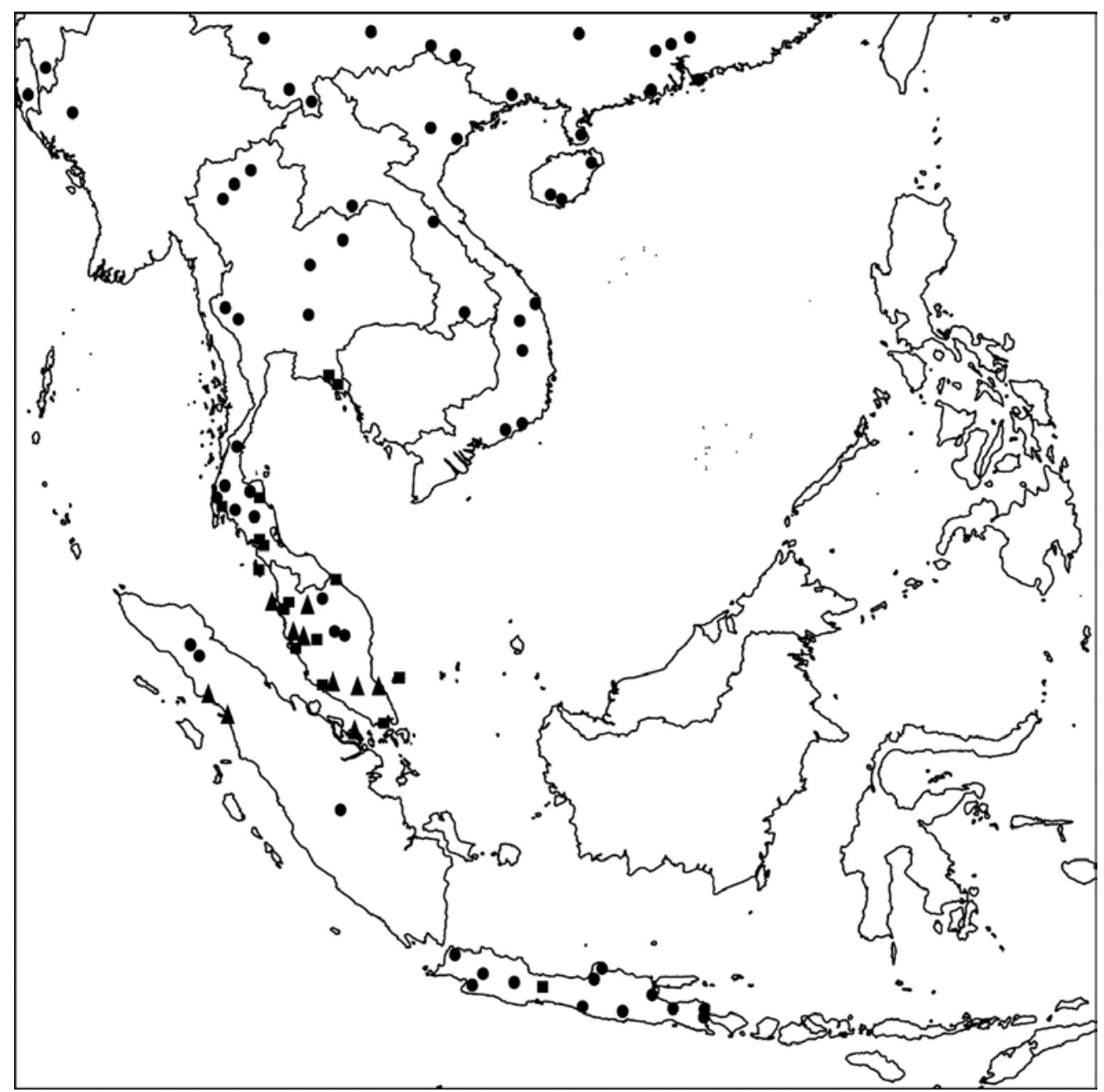

Fig. 18. Distribution of Litsea maingayi $(\boldsymbol{\Delta})$, L. monopetala $(\bullet)$ and L. myristicifolia $(\boldsymbol{\bullet})$.

$\&$ 1273]. The specimens of these gatherings are morphologically very similar and the $\mathrm{K}$ specimen [K000797147] is designated here as the lectotype.

26. Litsea monopetala (Roxb.) Pers., Syn. Pl. 2(1): 4 (1806); Allen, Ann. Missouri Bot. Gard. 25: 387 (1938); Grierson \& Long, Fl. Bhutan 1(2): 276 (1984); Kochummen in Ng, Tree Fl. Malaya 4: 161 (1989); Ngernsaengsaruay et al., Thai Forest Bull., Bot. 39: 77 (2011); Pendry in Watson et al., Fl. Nepal 3: 41 (2011). - Tetranthera monopetala Roxb., P1. Coromandel 2: 26, t. 148 (1800); Nees, Syst. Laur. 525 (1836). - Litsea polyantha Juss., Ann. Mus. Natl. Hist. Nat. 6: 211 (1805), nom. illeg.; Gamble, J. Asiat. Soc. Bengal, Pt. 2, Nat. Hist. 75(1): 143 (1912); Ridley, Fl. Malay Penins. 3: 118 (1924); Kochummen in Ng, Tree Fl. Malaya 4: 163 (1989). - TYPE: India, Coromandel, Roxburgh s.n. (lectotype BR [BR0000005113811], designated here). 
Tree 5-20 m tall, dbh c. $40 \mathrm{~cm}$; bark smooth, grey. Twigs slender, 2.3-4.3 mm thick, rounded in cross-section, glabrous to sparsely hairy when young; hairs yellowish, appressed; terminal leaf bud lanceolate, $2.9-3.8 \mathrm{~mm}$ long, apex acute, velutinous. Leaves alternate; leaf blade leathery, elliptic to oblong, 8-21 $\times 4-11.5 \mathrm{~cm}$, apex obtuse, acute or acuminate, base cuneate, sometimes asymmetric; secondary veins $6-11$ pairs, brochidodromous; tertiary veins scalariform-reticulate; surface above dark green, glabrous except for some hairs on midrib, midrib and secondary veins sunken, tertiary veins indistinct; surface below glaucous, sparsely hairy, midrib and secondary veins raised, tertiary veins distinct; petiole half-terete, $10-25 \mathrm{~mm}$ long, sparsely hairy, not swollen. Inflorescences clusters of umbels, 1-2.3 cm long, arranged along branchlets among and below the leaves; umbels $1-2 \mathrm{~cm}$ in diameter, sparsely hairy; bracts (4-)5, suborbicular, concave, 3-6 3 3-4.5 mm, sparsely hairy outside; infructescence with 1-6 fruits. Flowers yellow-white; male flowers $6-8$ in each umbel, perianth lobes 6 , obovate, $2-3 \times 0.8-1 \mathrm{~mm}$, sparsely hairy, stamens 9 , unequal, $2-3 \mathrm{~mm}$ long, sparsely hairy, anthers $0.5-1 \mathrm{~mm}$ long; female flowers $6-8$ in each umbel, perianth lobes 6, oblong, $2.5-3 \times 0.5-1 \mathrm{~mm}$, sparsely hairy, ovary ovoid, $1.5-2 \mathrm{~mm}$ in diameter, glabrous, style $2-2.5 \mathrm{~mm}$ long, stigma peltate. Fruits ellipsoid, $6.8-11 \times 4-8 \mathrm{~mm}$, smooth, glabrous, glossy, dark red, dark purple and black when mature; cupule shallow, 4-6 $\times 2-5 \mathrm{~mm}$, sparsely hairy, margins entire; stalk 5-12 mm long, slightly hairy, not swollen.

Distribution. Pakistan, India, Bangladesh, Nepal, Bhutan, China, Myanmar, Thailand, Cambodia, Laos, Vietnam, Peninsular Malaysia, Sumatra and Java (see Fig. 18).

Ecology. Often growing near streams in a wide variety of habitats, at $25-1600 \mathrm{~m}$. Flowering from January to May; fruiting from March to August.

Provisional IUCN conservation assessment. This species is known from about 200300 localities and has a very large extent of occurrence (EOO of 9,509,142 $\mathrm{km}^{2}$ ) and area of occupancy (AOO of $640 \mathrm{~km}^{2}$ ). Given its distribution and the fact that it can grow in secondary vegetation, an assessment of globally Least Concern is proposed.

Specimens examined. PENINSULAR MALAYSIA: Penang: Penang Hill, 12 Mar 1996, Van Balgooy 7215 (KEP); Government Hill, Dec 1895, Ridley 7065 (BM). Kelantan: Kuala Krai, 30 Mar 1995, Latiff 4170 (KEP); Ulu Sungai Sat, 8 Mar 1976, Mhd Shah \& Samsuri MS 3847 (KEP). Pahang: Sungai Tembeling National Park, 24 Feb 1973, Ng FRI 20880 (KEP); Bukit Terom, 5 Mar 1968, Mhd Shah MS 1580 (K, KEP); Taman Negara, 23 Apr 1975, Ang FRI 23364 (K, KEP). Selangor: Ulu Selangor, 29 Dec 1946, Unknown 60613 (KEP).

Notes. In the original description of Tetranthera monopetala (Roxburgh, 1800) the name was based on material from the Coromandel Coast in India. Only one specimen [BR0000005113811] collected by Roxburgh could be found and this specimen is designated here as the lectotype. 
27. Litsea myristicifolia (Wall. ex Nees) Hook.f., Fl. Brit. India 5: 172 (1886); Ridley, J. Straits Branch Roy. Asiat. Soc. 33: 131 (1900); Ridley, Fl. Malay Penins. 3: 125 (1924); Corner, Wayside Trees Mal. 348 (1940); Kochummen in Ng, Tree Fl. Malaya 4: 161 (1989); Keng, Concise Fl. Singapore, vol. 1, Gymn. Dicot. 19 (1990); Ngernsaengsaruay et al., Thai Forest Bull., Bot. 39: 79 (2011). - Tetranthera myristicifolia Wall. ex Nees in Wallich, P1. Asiat. Rar. 2: 67 (1831); Nees, Syst. Laur. 555 (1836). - Cylicodaphne myristicifolia (Wall. ex Nees) Meisn. in DC., Prodr. 15: 208 (1864). - TYPE: [Peninsular Malaysia], Penang, from the hills, 1824, Wallich s.n. [EIC 2548] (lectotype K-W [K001116392], designated by Ngernsaengsaruay et al., Thai Forest Bull., Bot. 39: 79 (2011); isolectotypes BM [BM000951043 p.p.], K [K000357612], K-W [K001116393, K001116394]).

Cylicodaphne myristicifolia var. acutata Meisn. in DC., Prod. 15: 209 (1864), syn. nov. - TYPE: Singapore, September 1822, Wallich 1831 [EIC 4129] (lectotype K [K000797066], designated here).

Tree (1-)6-27 m tall, dbh 15-60 cm, trunk with short buttresses up to $1 \mathrm{~m}$ high; bark grey-brown, lenticellate, smooth to scaly, inner bark pale yellow to reddish, sapwood pale yellow. Twigs slender, 2-3 mm thick, round in cross-section, glabrous, slightly aromatic when cut; terminal leaf bud 3.6-5.6 $\mathrm{mm}$ long, glabrous, apex acuminate with a long, keeled point. Leaves alternate, young leaves pink-red; leaf blade leathery, elliptic, obovate-oblong or obovate, $7.5-26 \times 2.5-10 \mathrm{~cm}$, apex acute or obtuse, base cuneate, drying greenish; secondary veins 7-12 pairs, curving near the margin, not brochidodromous; tertiary veins finely reticulate; surface above deep green, glossy, glabrous, midrib sunken above, secondary veins flattened or sunken, tertiary veins faintly visible; surface below glaucous and pale brown, glabrous, midrib and secondary veins raised, tertiary veins faintly visible; petiole 10-30 mm long, slightly swollen, channelled, glabrous. Inflorescences clusters of umbels, 1-2.8 cm long, in axils of leaves, along branchlets or at apex of branchlets; umbels $5-10 \mathrm{~mm}$ in diameter; bracts 4, decussate, suborbicular or broadly ovate, concave, 4-5 × 3-5 mm, coriaceous, glabrous, yellow-green. Flowers white, pale green to yellow; male flowers 5-6 in each umbel, perianth lobes 6, obovate-oblong, oblong, 3-3.5 $\times 0.8-1.5 \mathrm{~mm}$, glabrous, stamens 9-12, unequal, 2-4 mm long, glabrous, anthers 0.8-1.5 mm long; female flowers 5-7 in each umbel, perianth lobes 6, ovate, ovate-oblong or oblong, 2-3 $\times$ $0.8-1 \mathrm{~mm}$, glabrous, ovary globose or subglobose, $0.8-1 \mathrm{~mm}$ in diameter, glabrous, style 2-2.5 mm long, stigma peltate. Fruits (sub)globose, $7-13 \mathrm{~mm}$ in diameter, apex round, glabrous, white when mature; cupule a deep cup, 8-10 $\mathrm{mm}$ high, 6-12 $\mathrm{mm}$ in diameter, glabrous, margins entire; fruiting pedicels thick, 8-20 mm long, glabrous; stalk gradually thickening distally, $8-15 \times 2-3.5 \mathrm{~mm}$, glabrous.

Distribution. Southeast Myanmar, Peninsular Thailand, Peninsular Malaysia and Singapore (see Fig. 18). In Peninsular Malaysia, found throughout apart from Johor. 
Ecology. Growing in primary and secondary forests, sometimes on clay or over granite, or found along the back of mangrove swamps, at 0-500 $\mathrm{m}$ altitude. Flowering from June to February; fruiting from January to May.

Vernacular names. Penagak nasi, Medang kladi, Medang klayar, Medang etam, Medang baros, Medang assam, Medang kunyit, Merabok (Malay).

Provisional IUCN conservation assessment. This species is known from about 15-20 localities and has a relatively large extent of occurrence (EOO of $398,246 \mathrm{~km}^{2}$ ) and area of occupancy (AOO of $92 \mathrm{~km}^{2}$ ). For these reasons, and because it can grow in secondary vegetation, an assessment of globally Least Concern is proposed.

Specimens examined. PENINSULAR MALAYSIA: Kedah: Gunung Inas Reserve, 28 Feb 1928, Meh 12582 (SING); Jeniang, Nov 1925, Meh 9022 (SING); Gunung Ferai, Dec 1912, Guard 9048 (K); Langkawi, North Pulau Dayang, 12 Dec 1969, Whitmore FRI 15035 (KEP); Telok Udang, 20 Nov 1921, Haniff 7501 (SING). Penang: s.l., Jun 1898, Ridley 9430 (SING); road to Pout, Mar 1886, Curtis 769 (BM, K, SING [3 sheets]); ibidem, Oct 1886, Curtis 1079 (K, SING); Penang Hill, Dec 1895, Ridley 7071 (BM, K); Bukit Penang, Jul 1894, Curtis 769 (SING [2 sheets]); ibidem, Loh s.n. (BM); Pulau Penang, Mar 1893, Curtis 1079 (SING [3 sheets]); Bukit Penara, 1 Mar, 1905, Guard 3 (BM); Ayu Elam to Balik Pulau, Mar 1918, Haniff 3430 (K, SING); Mt Olivia, Dec 1910, Haniff 4064 (K, SING); Moniot, 16 Oct 1951, Sinclair SFN 39326 (K, SING); Government Hill, 6 Oct 1922, Burkill 8979 (SING); Dinding, 1897, Ridley s.n. (SING). Perak: Sungai Panchor, 16 Feb, Whitmore FRI 20573 (KEP); Larut, Buang, Nov 1883, King's Collector 5204 (BM, K [2 sheets], SING); Gunung Lang, 26 Mar 1938, Kiah SFN 35067 (K, KEP, SING [2 sheets]). Kelantan: Tumpat, 4 May 1939, Corner SFN 33525 (SING). Pahang: Telor Ridge, Nov 1901, Ridley 13725 (K, SING); Pasir Panjang, 9 Jun 1919, Usope 4205 (K); Balik Pulau Road, Mar 1918, Haniff SFN 3430 (SING); Pulau Tioman, 12 Apr 1962, Kadim \& Noor KN 563 (SING); Cameron Highlands, 24 Sep 1971, Loh FRI 19191 (KEP). Selangor: s.l., Cantley's Collector s.n. (SING). Negeri Sembilan: Tampin, 25 Jan 1916, Burkill SFN 1422 (BM [2 sheets]); ibidem, 25 Jan 1916, Nur SFN 1420 (SING); ibidem, 3 May 1918, Burkill 3224 (K); Gunung Tampin, 2 Nov 1922, Holttum 9528. (K); ibidem, 16 Feb 1917, Ridley s.n. (K); Pasir Pamjang, 9 Jun 1919, Geope FMS 4205 (SING). Malacca: s.l., Cumming 2321 (BM, K); s.l., Griffith 15513 (BM); s.l., Griffith s.n. (K); s.l., 18 Mar 1888, Alvins s.n. (SING [3 sheets]); Ayer Paugo, Dec 1888, Denny 97 (BM, K, SING); Kuala Tinggi, Feb 1889, Derry 910 (SING); ibidem, 1892, Derry 916 (SING); Cape Rachado, 20 Jan 1970, Kochummen FRI 2488 (KEP); Mackap, Tebung Road, Apr 1892, Derry 1008 (BM, K); Sungai Udang, Nov 1893, Goodenough 1681 (BM, SING); Alor Gajak, Dec 1898, Ridley 10026 (K); Tampin, 14 Dec 1915, Burkill 1369 (BM [2 sheets], SING); Sungai Tebony, 30 Jun 1916, Burkill 1436 (K, SING); Briau Reserve, 9 Apr 1891, Corporal Hetehil 674 (SING); Cape Rachado, 29 Jan 1967, Ng FRI 1894 (K, KEP, SING); Sungai Udang, 7 Apr 1891, Alvins 664, 690 (SING); ibidem, Nov 1893, Ridley 1603 (SING).

SINGAPORE: s.l., Cantley's Collector 3081 (SING); Economic Gardens, 1894, Ridley 6096 (BM, K, SING); Geylang, 1893, Ridley 4824 (BM, K, SING); Loyang Ave, 1999, Lai LJ 548 (SING); Changi, 1892, Ridley 4705 (SING); ibidem, 1894, Ridley 5973 (SING); ibidem, 1908, Ridley 13331 (BM, K, SING); ibidem, 24 Dec 1922, Burkill 10010 (BM, K, SING); Changi Road, 14 Jan 1933, Teruya 2180 (KEP, SING); Upper Changi Road, 31 May 2003, Ganesan SKG 6 (SING); Changi, Hendon Road, 23 Apr 2004, Ganesan SKG 57 (SING); ibidem, 23 Apr 
2004, Ganesan SKG 67 (SING); Changi Air Base, 24 Feb 2005, Ganesan SKG 82 (SING); Pulau Ubin, 21 Jan 2003, Gwee et al. GAT 185 (SING); ibidem, 1 Oct 2003, Gwee et al. GAT 359 (SING).

Notes. The isolectotype collection of Litsea myristicifolia at BM (Wallich s.n. [EIC 2548]) has one glabrous flowering twig with leaves and a separate sterile twig which is covered with short orange hairs. The two twigs are otherwise very similar in general appearance. However, this is clearly a mixed collection of a fertile gathering of Litsea myristicifolia with a sterile twig of a species of Myristicaceae. The four specimens in $\mathrm{K}$ and $\mathrm{K}-\mathrm{W}$ are all glabrous and do belong to Litsea myristicifolia.

In the original description of Cylicodaphne myristicifolia var. acutata Meisn. (Meissner, 1864), two gatherings were mentioned: Cuming 2321 and Wallich 4129, each with only one specimen (K000797065 and K000797066 respectively). The Wallich 1831 [EIC 4129] is designated here as the lectotype.

28. Litsea noronhae Blume, Bijdr. Fl. Ned. Ind. 11:561 (1826); Ridley, F1. Malay Penins. 3: 128 (1924); Kochummen in Ng, Tree Fl. Malaya 4: 162 (1989). - Cylicodaphne noronhiana (Blume) Blume, Mus. Bot. 1: 388 (1852). - TYPE: [Indonesia], Java, Blume s.n. (lectotype L [L0927102], designated here).

Litsea noronhae Blume var. hexandra Gamble, J. Asiat. Soc. Bengal 75: 180 (1912); Ridley, Fl. Malay Penins. 3: 129 (1924). - TYPE: [Peninsular Malaysia], Selangor, Ginting Biday, December 1896, Ridley 7620 (lectotype K [K000797145], designated here).

Shrub or tree 6-15 $\mathrm{m}$ tall. Twigs stout, 6-6.8 $\mathrm{mm}$ thick, sparsely hairy when young; hairs yellowish, appressed; terminal leaf bud ovoid, c. $3.5 \mathrm{~mm}$ long, velutinous. Leaves alternate; leaf blade thinly leathery, oblanceolate, 35-45 × 13-20 cm, apex rounded, base cuneate; secondary veins 17-20 pairs, curving near the margin; tertiary veins scalariform to reticulate; surface above glabrous, midrib and secondary veins sunken, tertiary veins distinct; surface below glaucous, glabrous, midrib and secondary veins raised to sunken, tertiary veins distinct; petiole half-terete, 30-50 mm long, swollen, sparsely hairy (hairs yellowish, appressed). Inflorescences with the appearance of a raceme of umbels, 2-6 cm long, borne on leafless twigs, densely hairy when young, glabrescent; umbels $0.5-1 \mathrm{~mm}$ in diameter; bracts 4, suborbicular, concave, 5.8-6.8 $\times 3.5-4.5 \mathrm{~mm}$, coriaceous, glabrous. Flowers white; male flowers 4 in each umbel, perianth lobes 6 , oblong, 4.2-5 × 1.9-2.2 mm, glabrous, stamens 9-12, unequal, 3.4-6 mm long, sparsely hairy, anthers 1.2-2.4 mm long; female flowers unknown. Fruits globose 6.8-8.7 × 7.3-7.5 mm, apex round, smooth, glabrous, red when mature, shiny; cupule shallow, membranous, 6.6-7 × 3-3.7 mm, margins entire, sparsely hairy, green; stalk swollen 4-5 × 2-3 mm, sparsely hairy.

Distribution. Peninsular Malaysia, Sumatra, Java and Lombok (see Fig. 19). 


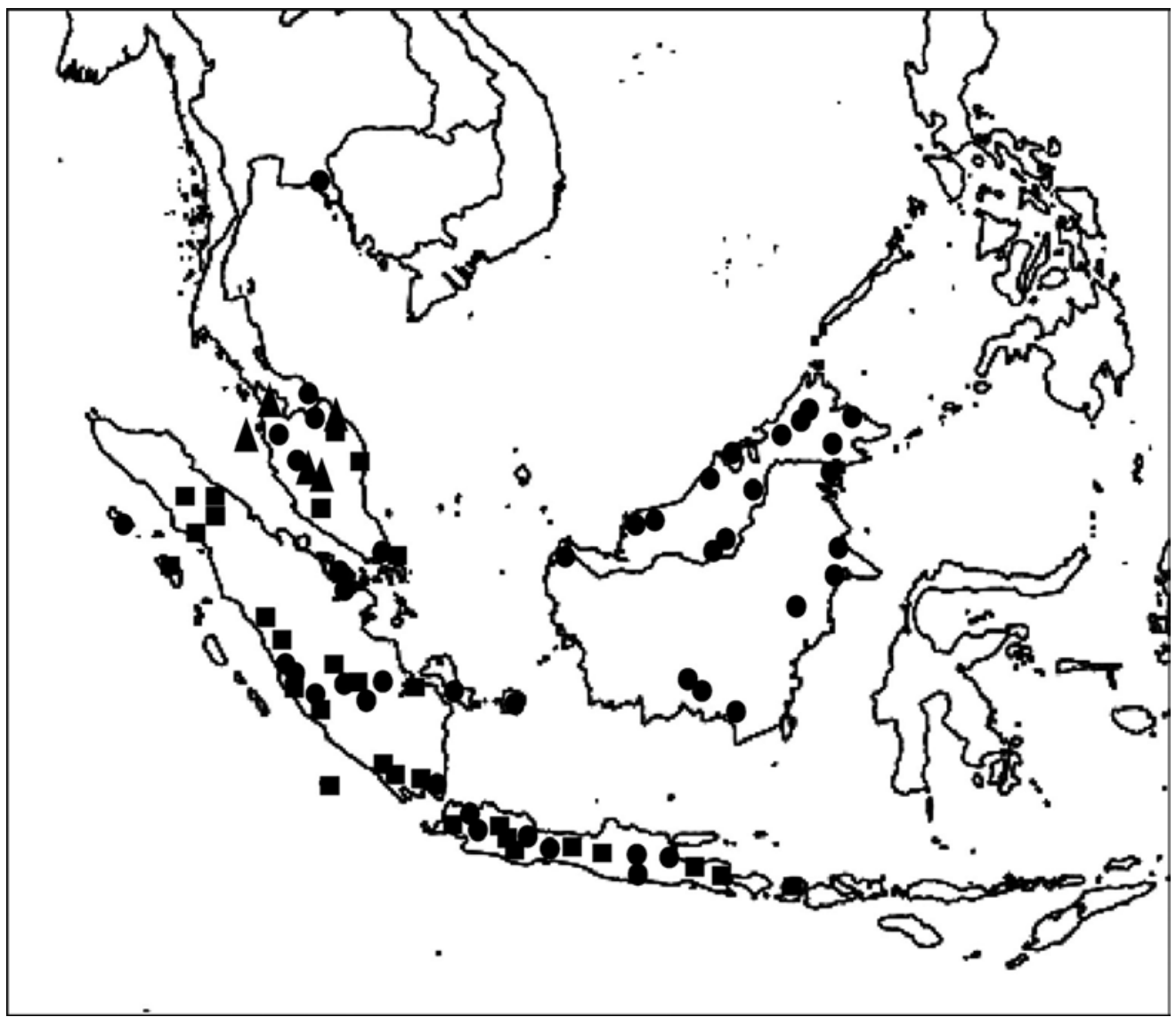

Fig. 19. Distribution of Litsea noronhae $(\boldsymbol{\bullet})$, L. penangiana $(\boldsymbol{\Delta})$ and L. resinosa $(\bullet)$.

Ecology. Growing in lowland and hill forests, sometimes near streams, at c. $150 \mathrm{~m}$ altitude. Flowering in December; fruiting from May to September.

Vernacular name. Kayu moyang (Temuan).

Provisional IUCN conservation assessment. This species is known from about 100150 localities in total and has a large extent of occurrence (EOO of 1,558,048 $\mathrm{km}^{2}$ ) and area of occupancy (AOO of $320 \mathrm{~km}^{2}$ ) and therefore an assessment of globally Least Concern is proposed.

Specimens examined. PENINSULAR MALAYSIA: Kelantan: Ulu Sungai Lebir, 17 Sep 1967, Whitmore FRI 4383 (KEP); Ulu Sungai Lebir, 17 Sep 1967, Cockburn FRI 7128 (KEP); Sungai Negeri, Kuala Jenera, 17 Jul 1967, Whitmore FRI 4073 (KEP). Selangor: Ulu Langat, 15 May 1959, Gadoh anak Umbai KL 1487 (KEP). 
Notes. In the original description of Litsea noronhae (Blume, 1826: 561) the type material was said to have been gathered in Java, in the mountains, and to have the vernacular name mohmal. Only one sterile specimen [L0927100] has some of this data, and of all Blume's material of this species only one sheet has flowers [L0927102]. This last specimen is designated here as the lectotype.

In the original description of Litsea noronhae Blume var. hexandra Gamble (Gamble, 1912: 180) only one gathering is mentioned: Ridley 7620. The K specimen [K000797145] is designated here as the lectotype.

29. Litsea penangiana Hook.f., F1. Brit. India 5: 171 (1886); Kochummen in Ng, Tree Fl. Malaya 4: 163 (1989). - TYPE: [Peninsular Malaysia], Penang, Government Hill, February 1867, Maingay 2206 [Kew distribution no. 1258/2] (lectotype K [K000815135], designated here).

Shrub or tree 3-9 $\mathrm{m}$ tall, dbh 4-15 cm. Twigs slender $1.5-3.8 \mathrm{~mm}$, rounded in crosssection, velutinous when young; hairs yellowish to dark brown, curly; terminal leaf bud 5.4-7.2 mm long, lanceolate, apex acute, velutinous. Leaves alternate; leaf blade leathery, elliptic, 6.5-24 × 3-8 cm, apex obtuse, acute to acuminate, base cuneate, sometimes asymmetric; secondary veins 6-10 pairs, curving near the margin; tertiary venation reticulate; surface above shiny, glabrous, midrib sunken, secondary veins slightly raised to flattened, tertiary veins indistinct; surface below glaucous, glabrous to very sparsely hairy on midrib and secondary veins, midrib and secondary veins raised, tertiary veins indistinct; petiole half-terete, $10-25 \mathrm{~mm}$, (slightly) swollen at base, velutinous to glabrous. Inflorescences clusters of umbels, $0.5-0.7 \mathrm{~cm}$ long, arising in leaf axils and from leafless twigs, umbels 10-20 mm long; bracts 4, decussate, suborbicular, concave, 4-4.4 × 2-3 mm, coriaceous, velutinous. Flowers yellow; male flowers 5 in each umbel, perianth lobes 6 , oblong, 2.4-2.6 $\times 0.8-1 \mathrm{~mm}$, glabrous, stamens 12, unequal, 0.8-1.3 mm long, glabrous, anthers $0.7-1 \mathrm{~mm}$ long; female flowers 4-6 in each umbel, perianth lobes 6, oblong, 1.5-1.7 × 1-1.2 mm, densely hairy outside, glabrous inside, ovary globose, c. $0.6 \mathrm{~mm}$ in diameter, glabrous, style c. $2 \mathrm{~mm}$ long, stigma peltate. Fruits ellipsoid, 15-20 $\times 8-13 \mathrm{~mm}$, apex rounded to truncate, smooth, glabrous; cupule woody, warty, 8-10 $\times 12-14 \mathrm{~mm}$, margins entire to lobed, glabrous, perianth lobes 0-2.8 $\times 3-4 \mathrm{~mm}$, apex rounded, covering whole fruit when young to only lower $1 / 3$ when mature, glabrous, dark green; stalk $0-9 \times 2-3 \mathrm{~mm}$, not swollen.

Distribution. Endemic to Peninsular Malaysia, where it is known from Kelantan, Kedah, Penang and Pahang (see Fig. 19).

Ecology. Growing in hill and montane forests, at 600-1300 m. Flowering from July to November; fruiting from August to November. 
Vernacular name. Mempening.

Provisional IUCN conservation assessment. This species has a relatively small extent of occurrence (EOO of 46,435 $\mathrm{km}^{2}$ ) and a small area of occupancy (AOO of $28 \mathrm{~km}^{2}$ ). It grows in hill and montane forests that are under threat of deforestation and habitat destruction. For these reasons, it is assessed here as Endangered (B2ab(i,ii,iii)).

Specimens examined. PENINSULAR MALAYSIA: Kedah: Bukit Perak F.R., 27 Nov 1969, Chan FRI 13219 (KEP); ibidem, Scortechini 369 (K [2 sheets]). Penang: s.l., 1824, Phillips s.n. (K). Kelantan: Gunung Sap, 12 Oct 1934, Symington KEP 37762 (KEP). Pahang: Ulu Telom, 28 Aug 1931, Jaamat 29269 (KEP); Fraser's Hill, 29 Aug 1971, Loh FRI 19181 (KEP); ibidem, 27 Aug 1970, Kochummen FRI 16169 (KEP); ibidem, 23 Jul 1971, Kochummen FRI 16414 (KEP); ibidem, 7 Jul 1972, Kochummen FRI 16564 (KEP); ibidem, 19 Jul 1930, Mahmood FMS 22378 (KEP); ibidem, 16-30 Sep 1930, Burkill \& Holttum 8699 (BM, K, KEP); Kuantan, Bukit Berkelah, 23 Oct 1975, Mhd Shah et al. MS 3697 (KEP).

Notes. In the original description of Litsea penangiana (Hooker, 1886), two gatherings are cited: Phillips s.n. and Maingay 2206 [Kew distribution no. 1258/2], both from Penang. I could only find one specimen, a specimen in K [K000815135] of the second gathering, which is designated here as the lectotype.

30. Litsea resinosa Blume, Bijdr. Fl. Ned. Ind. 11: 562 (1826); Kochummen in Ng, Tree Fl. Malaya 4: 163 (1989); Ngernsaengsaruay et al., Thai Forest Bull., Bot. 39: 87 (2011). - Tetranthera resinosa (Blume) Nees, Syst. Laur. 550 (1836). - Malapoenna resinosa (Blume) Kuntze, Revis. Gen. Pl. 2: 573 (1891). - TYPE: [Indonesia], Java, Unknown s.n. (lectotype K [K000815281], designated by Ngernsaengsaruay et al., Thai Forest Bull., Bot. 39: 87 (2011)). (Fig. 20).

Litsea monticola Gamble, Bull. Misc. Inform. Kew 1910: 361 (1910); Ridley, Fl. Malay Penins. 3: 124 (1924). - TYPE: [Peninsular Malaysia], Perak, Larut, top of Gunung Ejon, December 1884, King's Collector 7000 (lectotype K [K000797020], first step designated by Ngernsaengsaruay et al., Thai Forest Bull., Bot. 39: 87 (2011), second step designated here; isolectotypes BM [BM000799119], E [E00393262, E00393263], K [K000797021], SING [SING0055934]).

Tree 10-30 m tall, dbh 20-60 cm; buttresses short, trunk with stilt roots in swampy habitats; bark grey, smooth with wide fissures, lenticellate, inner bark reddish, sapwood cream-coloured. Twigs slender, 3-7 mm thick, angular in cross-section, velutinous, soon glabrescent; hairs short, yellowish, appressed; terminal leaf bud $3.3-4.5 \mathrm{~mm}$ long, apex rounded, ovate, velutinous. Leaves alternate; leaf blade leathery, elliptic to obovate, $9-30 \times 2.5-15 \mathrm{~cm}$, apex acute to acuminate, base cuneate, sometimes asymmetric; secondary veins $7-16$ pairs, curving near the margin; tertiary veins scalariform-reticulate; surface above deep to dark green, glossy, glabrous, midrib and secondary veins sunken, tertiary veins faint; surface below glaucous, pale green, 


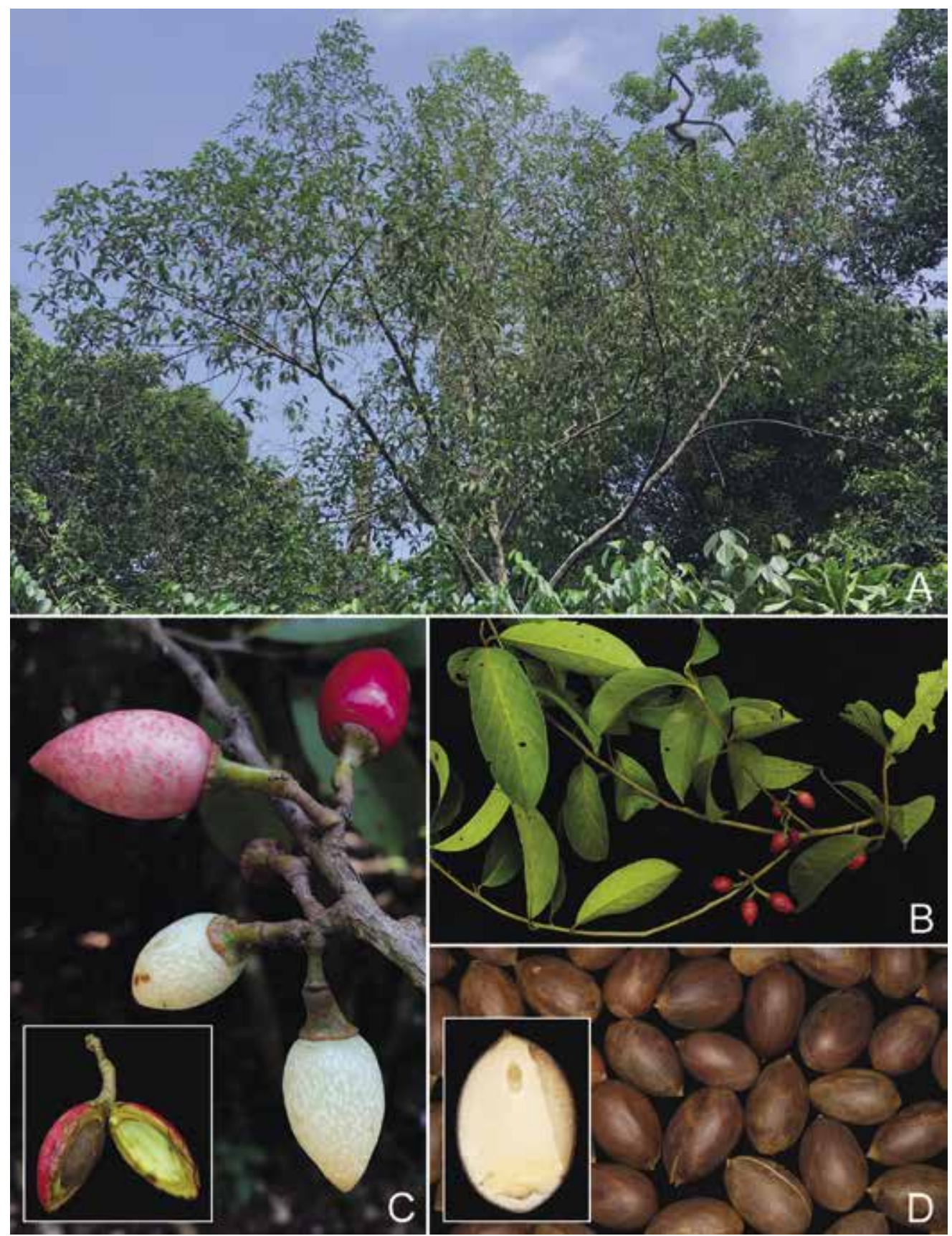

Fig. 20. Litsea resinosa Blume. A. Habit. B. A leafy branch. C. Fruits in different stages of maturation. Inset: Fruit split to reveal seed. D. Seeds. Inset: A halved seed. From Singapore; A-D from Upper Seletar; C inset from Nee Soon Swamp Forest, Vijayakumar SING2014-097. (Photos: A-D \& D inset, X.Y. Ng; C inset, P.K.F. Leong). 
glabrous or with few hairs on the veins, midrib and secondary veins raised, tertiary veins distinct; petiole channelled in cross-section, 10-30 mm long, slender, finely wrinkled, black. Inflorescences clusters of umbels, 1-2.4 cm long, borne in axils of leaves or along branchlets; umbels $0.7-0.9 \mathrm{~cm}$ in diameter; peduncles $0.4-1 \mathrm{~cm}$ long, densely to sparsely hairy; bracts 4-5, decussate, suborbicular or broadly ovate, concave, 3-7 $\times 2.5-5 \mathrm{~mm}$, glabrous to sparsely hairy outside. Flowers pale yellow; male flowers 4-7 in each umbel, perianth lobes 6, elliptic, obovate-lanceolate, 2-3.5 $\times 0.8-1 \mathrm{~mm}$, hairy, margins fimbriate, stamens 9-16, unequal, 1.5-3.5 mm long, sparsely hairy, anthers $0.5-1.5 \mathrm{~mm}$ long; female flowers 3-7 in each umbel, perianth lobes 6 , elliptic to obovate-lanceolate, $3-3.5 \times 0.8-1 \mathrm{~mm}$, hairy, ovary ovoid, $0.5-1 \mathrm{~mm}$ in diameter, glabrous, style 1-2.5 mm long, stigma inconspicuous. Fruits ellipsoid, 18-33 $\times 8-16$ $\mathrm{mm}$, apex acute, glabrous, rough when dried, dark red and shiny when mature; cupule shallow, 2.5-5 $\mathrm{mm}$ high, 6-10 $\mathrm{mm}$ in diameter, smooth, margins undulate, glabrous; fruiting pedicels 5-8 $\mathrm{mm}$ long, glabrous; stalk 6-12 $\mathrm{mm}$ long, slightly to strongly swollen, 2-6 mm thick, glabrous to sparsely hairy.

Distribution. Peninsular and southeastern Thailand, Peninsular Malaysia, Singapore, Sumatra, Borneo and Java (see Fig. 19).

Ecology. Growing in lowland to montane forests, often found in (peat) swamp forest, sometimes over granite, at $0-1500 \mathrm{~m}$ altitude. Flowering all year around; fruiting from August to March.

Provisional IUCN conservation assessment. This species is known from at least 200 localities in total and has a very large extent of occurrence (EOO of 3,630,976 $\mathrm{km}^{2}$ ) and area of occupancy (AOO of $348 \mathrm{~km}^{2}$ ) and therefore an assessment of globally Least Concern is proposed.

Specimens examined. PENINSULAR MALAYSIA: Penang: Moniot Road, Apr 1890, Curtis 2308 (BM). Perak: Taiping, Jan 1886, King's Collector 8454 (K); Larut, Dec 1883, King's Collector 5350 (K [3 sheets]); ibidem, Oct 1884, King's Collector 6683 (BM, K); Birch's Hill, 29 Feb 1924, Burkill \& Haniff 12866 (K, SING). Kelantan: Gunung Stong, 13 Aug 1969, Whitmore FRI 12420 (KEP). Terengganu: Sungai Tong F.R., 5 Jun 1962, Kochummen FFN 94772 (KEP, SING). Pahang: Tringkap, 11 Oct 1961, Burkill HMB 2874 (K, SING); ibidem, 23 May 1936, Holttum SFN 31402 (SING); ibidem, Sungai Schat, 13 Aug 1931, Jamaat 25198 (K, SING). Selangor: Gua Batu, Jul 1897, Ridley 8505 (K); Telok Reserve, 10 Oct 1937, Nur SFN 34058 (SING [3 sheets]); Klang, Baku F.R., 9 Nov 1953, Saw \& Lindang FFN 76025 (KEP, SING); ibidem, 9 Nov 1953, Sinclair SFN 40111 (KEP, SING); Fraser's Hill, 27 Oct 2010, Julius FRI 73621 (KEP).

SINGAPORE: Upper Seletar, behind carpark A, 7 Mar 2012, Hassan \& Lua SING2012058 (SING [3 sheets]); Nee Soon Swamp Forest, 20 Mar 2014, Vijayakumar SING2014-097 (SING).

Notes. In their paper dealing with the species from Thailand, Ngernsaengsaruay et al., (2011: 87) selected the K specimen of King's Collector 7000 as the lectotype for Litsea 
monticola. However, there are two sheets at $\mathrm{K}$ of this gathering. As only one of these can serve as the lectotype, the specimen [K000797020] is designated here in a second step lectotypification.

31. Litsea ridleyi Gamble, Bull. Misc. Inform. Kew 1910: 317 (1910); Ridley, F1. Malay Penins. 3: 120 (1924); Keng, Concise Fl. Singapore, vol. 1, Gymn. Dicot. 19 (1990); Davison et al., Singapore Red Data Book 226 (2008). - TYPE: [Singapore], 1893, Ridley 5101 (lectotype SING [SING0046619], designated by Ng, Gard. Bull. Singapore 57: 224 (2005); isolectotypes BM [no barcode], K [no barcode]). (Fig. 21).

Tree 7-25 $\mathrm{m}$ tall. Twigs slender to stout, 2-6.5 $\mathrm{mm}$ thick, rounded to angular in crosssection, densely hairy when young; hairs appressed to erect, yellowish to reddish brown; terminal leaf bud ovoid to lanceolate, apex acute, 5-10 $\mathrm{mm}$ long, velutinous. Leaves alternate; leaf blade papery, elliptic to (narrowly) lanceolate, $11-25 \times 3.4-5 \mathrm{~cm}$, apex acute to acuminate, base cuneate, margins straight; secondary veins 5-7 pairs, arising at c. $45^{\circ}$ to midrib, curving towards the margin; tertiary veins reticulate; surface above dark green, glabrous, midrib densely hairy, midrib and secondary veins sunken to flattened, tertiary veins distinct; surface below light green, glaucous, generally sparsely hairy, more densely hairy on and along the midrib and secondary veins (hairs appressed to erect, yellowish), midrib and secondary veins raised, tertiary veins distinct; petiole slightly swollen, half-terete, 7-10 mm long, velutinous to sparsely hairy (hairs appressed to erect, long, yellowish to light brown). Inflorescences clusters of umbels, $0.5-2 \mathrm{~cm}$ long, borne in axils of leaves or along branchlets; umbels 2-3.2 $\mathrm{mm}$ in diameter; bracts $4-5$, usually imbricate, orbicular, concave, 2-4 $\times 2-4 \mathrm{~mm}$, hairy outside. Flowers slightly fragrant; male flowers 3-8 in each umbel; tepals 5-6, elliptic or elliptic-lanceolate, subequal, 1.5-3.8 $\times 0.4-0.5 \mathrm{~mm}$, hairy, stamens 8-14, white, unequal, anthers $0.5-1.5 \mathrm{~mm}$ long, filaments $1-5 \mathrm{~mm}$ long, sparsely hairy; female flowers 3-6 in each umbel, tepals 5-6, elliptic to elliptic-lanceolate, subequal, $1-2.5 \times 0.4-0.8 \mathrm{~mm}$, sparsely hairy, ovary globose or ovoid, $0.5-1 \mathrm{~mm}$ in diameter, glabrous, style 1-2.5 mm long, stigma peltate, staminodes 7-12, linear, 0.5-2 mm long, hairy. Fruits globose, 13-14 mm in diameter, glabrous; cupule a shallow cup, 3-7 $\mathrm{mm}$ in diameter, sparsely hairy, margins entire; fruiting pedicels $2-7 \mathrm{~mm}$ long, sparsely hairy; stalk 8-9 mm long, sparsely hairy.

Distribution. This species is currently only verified as occurring in Singapore (see Fig. 22), where it is reported from forests throughout the country (but see notes below).

Ecology. Growing in lowland primary forests and in young and older secondary forests, from 0-80 m altitude. Flowering in February; fruiting from April to July.

Provisional IUCN conservation assessment. Davison et al. (2008) considered it to be Critically Endangered. 

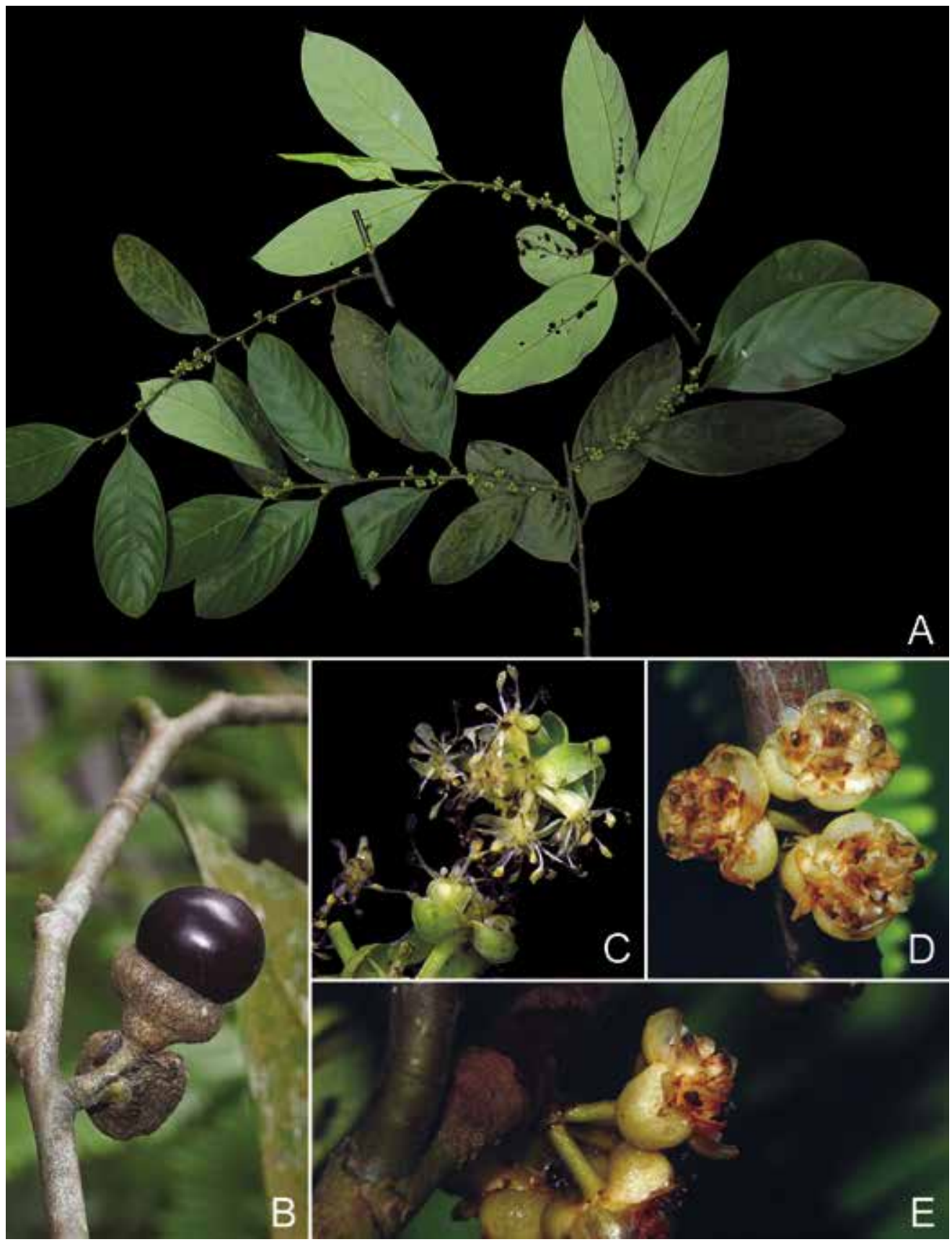

Fig. 21. Litsea ridleyi Gamble. A. Leafy branch with flower buds. B. Ripened fruit. C. Flowers at anthesis showing stamens prominently. D \& E. Flowers with stigmas featuring prominently. From Singapore; A-C from Bukit Timah Nature Reserve; D \& E from Sime Track. (Photos: A \& C, P.K.F. Leong; B, R.C.J. Lim; D \& E, X.Y. Ng). 


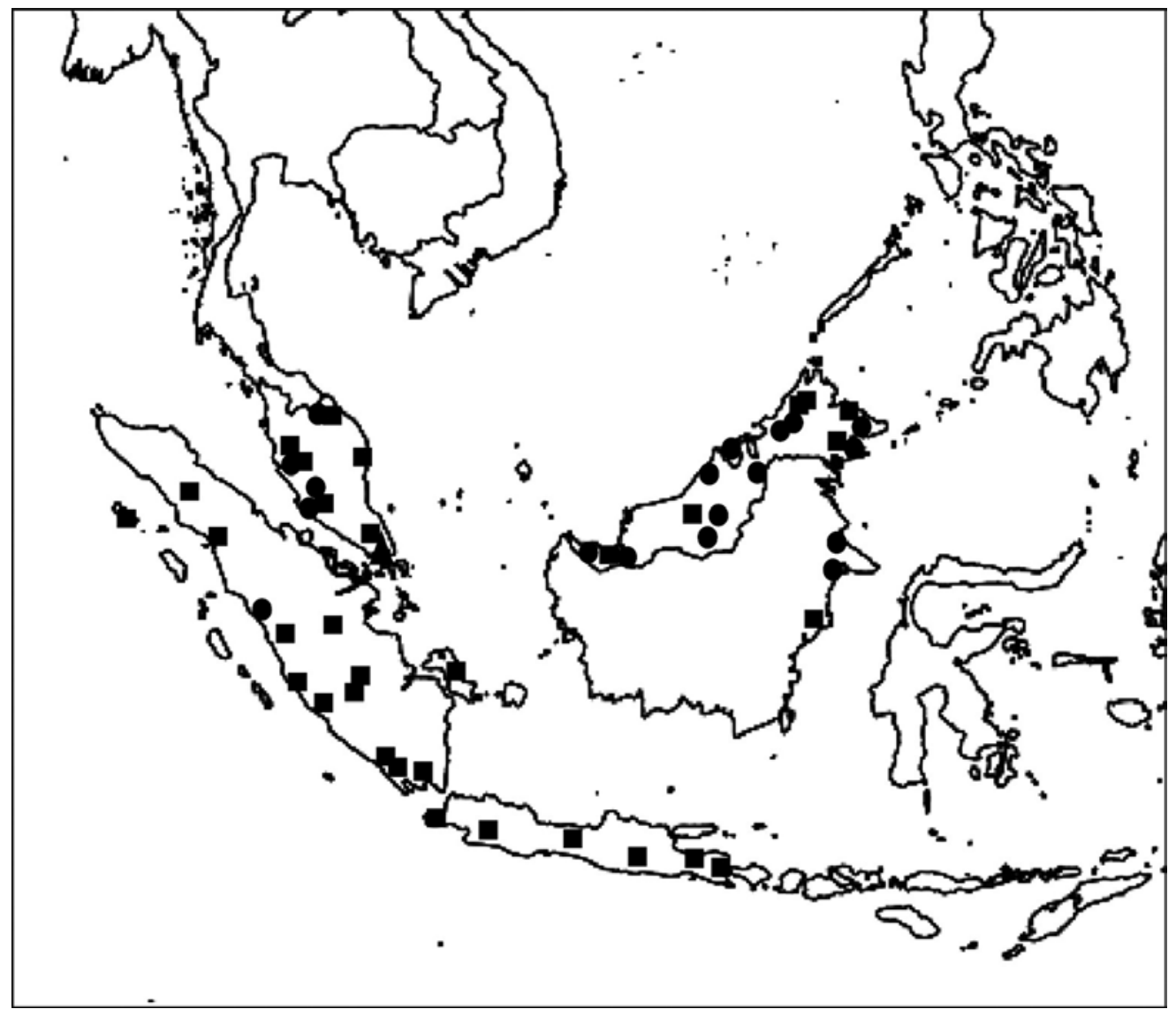

Fig. 22. Distribution of Litsea ridleyi ( $\mathbf{\Delta})$, L. robusta $(\boldsymbol{\bullet})$ and L. rubicunda $(\bullet)$.

Specimens examined. SINGAPORE: s.1., 1888, Cantley s.n (SING); Bukit Timah, 28 Feb 1982, Maxwell 83-61 (SING); ibidem, 14 Jul 1971, Hamzah H-23 (KEP, SING); ibidem, North View Path, 9 Jun 1970, Noor MN 1240 (SING); ibidem, 22 Apr 1974, Noor MN 1878 (SING); ibidem, Taban valley, 6 Jun 2019, Niissalo et al. SING2019-535 (SING); Upper Peirce, 19 Jan 2010, Gwee SING2010-143 (SING); MacRitchie, Sime Track, 17 Nov 2014, Leong et al. MR 2014-090 (SING); ibidem, Jun 2015, Leong et al. MR 2015-006 (SING); ibidem, transect 2, plot 6, 17 Mar 2015, Leong et al. MR 2015-032 (SING); ibidem, between Sime Track and Petaling Boardwalk, 24 Apr 2018, Lua et al. SING2018-421 (SING); Holland Road, 22 May 1893, Hullett s.n. (SING); Bukit Mandai, 22 May 1900, Ridley 10833 (SING).

Notes. In their paper on the endemic species of Singapore, Kiew \& Turner (2003: 174) mentioned that several specimens of this species are known from Borneo. I have not seen these specimens and therefore cannot verify this claim. $\mathrm{Ng}$ (2005: 222), however, when studying the specimens in Borneo, placed Litsea ridleyi in synonymy of Litsea accedens var. accedens. These two species can, however, easily be distinguished by the indumentum on the underside of the leaf blades and I do not treat them here as synonyms. It is possible that the material from Borneo earlier identified as Litsea ridleyi is indeed the widespread and variable L. accedens as identified by $\mathrm{Ng}$. 
32. Litsea robusta Blume, Bijdr. Fl. Ned. Ind. 11: 560 (1826); Ridley, Fl. Malay Penins. 3: 129 (1924); Kochummen in Ng, Tree Fl. Malaya 4: 163 (1989); Keng, Concise Fl. Singapore, vol. 1, Gymn. Dicot. 19 (1990); Ng, Gard. Bull. Singapore 57: 233 (2005). - Tetranthera robusta (Blume) Nees, Syst. Laur. 564 (1836). - Cylicodaphne robusta (Blume) Blume, Mus. Bot. 2(1): 11 (1856). - TYPE: [Indonesia], Java, Salak, Blume s.n. (lectotype U [U0002841], designated here; isolectotype BO [sheet no. BO1278382]).

Litsea persella Ridl., Agric. Bull. Straits \& Fed. Mal. States 5: 6 (1906), syn. nov. Cylicodaphne persella (Ridl.) Nakai, Bull. Tokyo Sci. Mus. No. 22: 32 (1948). - TYPE: [Malaysia], Kuching, September 1905, Ridley 12429 (lectotype K [K000815214], designated by Turner, Gard. Bull. Singapore 64: 232 (2012); isolectotype BM [BM000799049]).

Litsea sebifera auct. non Pers.: Blume, Bijdr. Fl. Ned. Ind. 11: 560 (1826); Gamble, J. Asiat. Soc. Bengal, Pt. 2, Nat. Hist. 75: 176 (1912); Ridley, Fl. Malay Penins. 3: 128 (1924); Ng, Gard. Bull. Singapore 57: 233 (2005).

Litsea glutinosa auct. non (Lour.) C.B.Rob.: Burkill, Dict. Econ. Prod. Malay Penins. 2: 1376 (1935); Ng, Gard. Bull. Singapore 57: 233 (2005).

Litsea longipes auct. non (Meisn.) Hook.f.: Ridley, J. Straits Branch Roy. Asiat. Soc. 33: $131(1900)$.

Tree 8-50 m tall, dbh $25-60 \mathrm{~cm}$; bark smooth to scaly, sometimes hooped, grey, sapwood yellow. Twigs slender to stout, 2.3-12 mm thick, rounded to angular in cross-section, densely hairy when young, soon glabrous; hairs appressed, yellowish; terminal leaf buds 9-15 mm long, apex acute, velutinous. Leaves alternate, slightly fragrant; leaf blade leathery, broadly elliptic to lanceolate, $(6-) 14-60 \times(4-) 6.8-30$ $\mathrm{cm}$, apex rounded to acute, sometimes with a very short tip, base cuneate, symmetric to asymmetric; secondary veins 10-20 pairs, curving and looping near the margin; tertiary veins scalariform-reticulate; surface above dark green, glabrous, midrib and main secondary veins sunken, tertiary veins distinct; surface below whitish grey to light green, glabrous to densely hairy (hairs appressed, long and short hairs present), midrib and secondary veins raised, tertiary veins prominent; petiole half-terete, 20-48 $\mathrm{mm}$ long, slightly swollen, glabrous. Inflorescences with the appearance of a raceme of umbels, 5-20 cm long, borne in the axils of leaves or along branchlets or terminal, umbels $8-13 \mathrm{~mm}$ in diameter; bracts $4-6$, usually imbricate, suborbicular, 4-7 $\mathrm{mm}$ in diameter, densely hairy, pale green-white; infructescence $6.5-9 \mathrm{~cm}$ long, with 1-3 fruits. Flowers (bright) yellow to white, (slightly) fragrant; male flowers 3-7 in each umbel, perianth lobes 6 , linear, apex acute, $1.5-2 \times 0.8-1 \mathrm{~mm}$, stamens $12,13,14$ or 15 , unequal, $1-3 \mathrm{~mm}$ long, sparsely hairy, anthers $0.5-1 \mathrm{~mm}$ long; female flowers c. 7 in each umbel, perianth lobes $6,2.3-3 \mathrm{~mm}$, apex acute, ovary elliptic, few hairs present, 1.4-1.7 mm long, style c. $4 \mathrm{~mm}$ long, stigma peltate. Fruits globose, 10-27 $\times 10-20 \mathrm{~mm}$, apex rounded to acute, smooth, glabrous, violet when mature; cupule 
woody, 17-28 $\mathrm{mm}$ in diameter, patent to covering at least half of the mature fruit, margins entire, dark green; stalk strongly swollen, 4.5-10 mm thick, 14-18 mm long.

Distribution. Peninsular Malaysia, Singapore, Sumatra, Borneo, Java and Bali (see Fig. 22).

Ecology. Growing in lowland and hill forests, often near streams, sometimes over granite or on loam, at 90-900 m altitude. Flowering from November to May; fruiting from March to November.

Vernacular name. Mullay (Singapore).

Provisional IUCN conservation assessment. This species is known from about 100 localities in total and has a large extent of occurrence (EOO of 2,821,998 $\mathrm{km}^{2}$ ) and area of occupancy (AOO of $164 \mathrm{~km}^{2}$ ) and therefore an assessment of globally Least Concern is proposed.

Specimens examined. PENINSULAR MALAYSIA: Kedah: Gunung Lang, 25 Mar 1938, Kiah SFN 35060 (K [2 sheets], SING). Penang: Government Hill, 1890, Curtis 795 (BM). Perak: Larut, Apr 1884, King's Collector 5867 (BM, K [2 sheets]); ibidem, Apr 1884, King's Collector 5878 (SING [3 sheets]); ibidem, May 1884, King's Collector 6167 (BM, K [2 sheets]); ibidem, Goping, Apr 1884, King's Collector 5781 (BM, K [2 sheets], SING [2 sheets]); ibidem, Sep 1885, King's Collector 8266 (K [2 sheets]); Slim River, 29 Nov 1966, Ng FRI 1774 (K); Gunung Pondok, 7 Jun 1930, Henderson SFN 23810 (BM, KEP). Kelantan: Pergau, 7 Oct 1992, Karim \& Mhd Shah NK 60 (SING); Jeli, Sungai Long, 7 Oct 1992, Zainudin 4311 (KEP); Bukit Baka, Ulu Sat, 22 Oct 2008, Teo \& Din KL 5603 (KEP). Terengganu: Gunung Padang, Ulu Brang, 16 Sep 1969, Whitmore FRI 12623 (KEP); Kemaman, Bukit Lagong, 10 Nov 1935, Corner SFN 30360 (BM, K, KEP, SING). Pahang: Sungai Mai estate, 26 Mar 1959, Kadim \& Mahmood KN 21 (K, SING); Ulu Tembeling, 20 Jul 1929, Henderson SFN 21981 (K, SING); Lesong F.R., 5 May 1982, Khairuddin FRI 31756 (K, KEP, SING); Sungai Telom, 1 Jun 1971, Whitmore FRI 20077 (KEP, SING). Selangor: Sungai Buluh, 6 Mar 1915, Ridley s.n. (K [2 sheets]); Gua Balu, Jul 1897, Ridley 8529 (K, SING); Bukit Haggong, 23 Jan 1980, Kochummen KEP 79035 (KEP, SING); Bukit Lagong F.R., 29 Oct 1959, Kochummen KEP 93458 (SING); ibidem, 23 Jan 1960, Kochummen KEP 75035 (SING); ibidem, 13 Aug 1960, Sow \& Lindong 94543 (K, SING); Bukit Lagong F.R., 21 Oct 1954, Sow 76050 (SING); ibidem, 12 Feb 1970, Whitmore FRI 15139 (KEP); ibidem, 12 Jun 1975, Putz FRI 23650 (KEP); Ulu Gombak, 26 Feb 1927, Strugnell FMS 12669 (KEP); ibidem, 3 Nov 1960, Ahmad KEP 97702 (K, KEP); Ginting, 12 May 1925, Hamid 10245 (SING); Kepong, 27 Apr 1950, Wyatt-Smith KEP 66517 (K, SING); ibidem, 16 Sep 1954, Kochummen KEP 75985 (K, KEP, SING [2 sheets]); ibidem, 20 Mar 1929, Sow 16415 (KEP, SING); ibidem, 2 Apr 1929, Sow 16435 (KEP, SING); ibidem, 15 Apr 1950, Wyatt-Smith KEP 66617 (K, KEP, SING); ibidem, 3 Sep 1927, Pawauchee 13662 (SING). Kuala Lumpur: s.1., 9 Sep 1950, Wyatt-Smith KEP 71278 (K); Gisting-Simpoh Road, 9 Sep 1950, Wyatt-Smith KEP 71285 (K, SING); Bukit Nanas, 9 Apr 2015, Norzielawati FRI 83014 (KEP); ibidem, 9 Apr 2015, Norzielawati FRI 83008 (KEP). Negeri Sembilan: Jelebu, 12 Oct 1969, Everett FRI 104904B (KEP). Johor: Kampong Peta, 3 May 1986, Saw FRI 34243 (KEP, SING); Sempang Rengam, 21 Apr 1957, Sinclair 8940 (SING).

SINGAPORE: Balestier Road, 10 Nov 1890, Goodenough s.n. (SING). 
Notes. The leaf morphology in this species is very variable, both in size and shape and in the degree of hairiness. Several different species have been described based on this variation. In his treatment of the Bornean species, $\mathrm{Ng}$ (2005) recognised Litsea robusta as distinct from L. garciae S.Vidal in leaf shape (leaf base symmetric in L. robusta and asymmetric in L. garciae) and hairiness (sparsely hairy on lower leaf surface in $L$. robusta and velutinous in L. garciae). However, the indumentum characters are variable, leading to many intermediates, and younger leaves are distinctly hairier than older ones. The shape differences are more difficult to characterise; sometimes both clearly asymmetric and symmetric leaf bases are found on the same specimen. I therefore agree with Kochummen (1989) in his treatment of the genus in the Tree Flora of Malaya and only recognised one species.

In the original publication of Litsea robusta (Blume, 1826: 560) the type gathering was collected at Salak on the island of Java. I could only find one specimen of this gathering at $\mathrm{U}$ [U0002841] and this is designated here as the lectotype.

33. Litsea rubicunda Kosterm., Reinwardtia 7: 351 (1968); Kochummen in Ng, Tree Fl. Malaya 4: 163 (1989). - TYPE: [Malaysia], Sarawak, 3rd Division, Simpang Tiga Ulu Mayeng, Kakus, 5 October 1963, Paie S 19262 (holotype L [L0036803]; isotypes K [K000815278], KEP [184828], MEL [MEL2390524]).

Shrub or tree 6-20 m tall, dbh 3-5 cm. Twigs slender 2-4.1 mm thick, rounded in cross-section, smooth, densely hairy when young, quickly becoming glabrous; hairs yellowish brown, curly; terminal leaf bud 2.7-9 mm long, lanceolate, apex acute, velutinous. Leaves alternate; leaf blade membranous, elliptic, 7-18 $\times 2-6 \mathrm{~cm}$, apex acuminate, base cuneate to attenuate, margins straight, drying pinkish; secondary veins 5-7 pairs, brochidodromous; tertiary veins reticulate; surface above glabrous, midrib sunken, secondary veins flattened, tertiary veins indistinct; surface below glabrous, midrib and secondary veins raised, tertiary veins indistinct; petiole $13-20 \mathrm{~mm}$ long, slender, glabrous. Inflorescences clusters of umbels $2.6-4.4 \mathrm{~cm}$ long, borne in axils of leaves or along branchlets below the leaves, glabrous, umbels $8-9 \mathrm{~mm}$ in diameter; bracts 4, (sub)orbicular, concave, 2.7-5.2 × 1.8-4 mm, glabrous outside and inside; infructescence with 1-3 fruits. Flowers pale white; male flowers c. 7 in each umbel, perianth lobes 6 , (ob)lanceolate, $2.4-5 \times 1.4-1.8 \mathrm{~mm}$, sparsely hairy, stamens 6-9, unequal, $2.2-2.7 \mathrm{~mm}$ long, sparsely hairy, anthers $1.3-1.5 \mathrm{~mm}$ long; female flowers unknown. Fruits globose, 12-15 $\times 10-12 \mathrm{~mm}$, smooth, glabrous; cupule shallow, $7-10 \times 1.5-3 \mathrm{~mm}$, margins entire to shallowly lobed, perianth lobes $0-1.8 \mathrm{~mm}$, apex rounded; stalk tapering distally, $4-11 \times 1.8-2.8 \mathrm{~mm}$.

Distribution. Peninsular Malaysia, Sumatra and Borneo (see Fig. 22).

Ecology. Growing in hill and montane forests, at 250-1200 m altitude. Flowering from May to June; fruiting from August to September. 
Provisional IUCN conservation assessment. This species is known from about 20-30 localities and has a large extent of occurrence (EOO of 1,069,780 $\mathrm{km}^{2}$ ) and area of occupancy (AOO of $136 \mathrm{~km}^{2}$ ). Given the large extent of occurrence and the number of known localities, an assessment of globally Least Concern is proposed.

Specimens examined. PENINSULAR MALAYSIA: Pahang: Ulu Sungai Ikau, 24 Aug 1931, Jaamat 27642 (KEP); Pine Tree Hill, 11 Jun 1965, Kochummen KEP 93135 (KEP). Selangor: Kepong, 17 Sep 1955, Matan 76761 (K, KEP); Genting Sempak, 10 Aug 1927, Pewaukee 13075 (KEP).

34. Litsea sessiliflora Hook.f., F1. Brit. India 5: 160 (1886); Ridley, F1. Malay Penins. 3: 131 (1924); Kochummen in Ng, Tree Fl. Malaya 4: 164 (1989); Ng, Gard. Bull. Singapore 57: 239 (2005). - TYPE: [Peninsular Malaysia], Penang, Maingay s.n. [Kew distribution no. 1511] (lectotype K [K000229422], designated here; isolectotypes BM [no barcode], K [no barcode]).

Litsea ujongensis Gamble, Bull. Misc. Inform. Kew 1910: 366 (1910); Ridley, Fl. Malay Penins. 3: 131 (1924); Kochummen in Ng, Tree Fl. Malaya 4: 164 (1989). TYPE: [Peninsular Malaysia], Malacca, Gunong Sedang, Cantley 5848 (lectotype K [K000797132], designated here).

Litsea ujongensis Gamble var. nervosa Gamble, Bull. Misc. Inform. Kew 1910: 366 (1910); Ridley, Fl. Malay Penins. 3: 131 (1924); Kochummen in Ng, Tree Fl. Malaya 4: 164 (1989). - TYPE: [Peninsular Malaysia], Perak, Gunung Batu Pateh, lower camp, Wray 1129 (lectotype K [K000797134], designated here).

Shrub or tree 1.5-6 m tall, dbh 5-12 cm; bark smooth, dark grey, inner bark yellow, sapwood pale yellow. Twigs slender, 2.7-3.6 mm thick, velutinous; hairs erect, reddish brown; terminal leaf bud ovoid, 5.3-8.8 $\mathrm{mm}$ long, apex acute, velutinous. Leaves (sub)opposite; leaf blade elliptic to (ob)lanceolate, 13-34 × 3-10.6 cm, apex acuminate, often with a sharp tip, base rounded or broadly cuneate, margins straight; secondary veins 13-20 pairs, curving near the margin; tertiary veins scalariformreticulate; surface above glabrous except sparsely hairy on midrib, midrib raised to sunken, secondary veins sunken, tertiary veins distinct; surface below sparsely hairy to velutinous on veins (hairs erect, reddish), midrib and secondary veins raised, tertiary veins distinct; petiole half-terete, 5-12 mm long, (slightly) swollen, velutinous (hairs erect, reddish). Inflorescences clusters of umbels $0.6-1 \mathrm{~cm}$ long, borne in axils of leaves or along branchlets below the leaves, umbels $4-5 \mathrm{~mm}$ in diameter; bracts 4 , imbricate, (sub)orbicular, concave, 2.3-3.5 × 1.9-2.5 mm, velutinous outside, glabrous inside; infructescence with 1-3 fruits. Flowers: male flowers c. 3 in each umbel, perianth lobes 6 , lanceolate, 2.4-2.8 $\times 1.2-1.3 \mathrm{~mm}$, apex acute, sparsely hairy, stamens 9, unequal, $0.8-1 \mathrm{~mm}$ long, sparsely hairy, anthers $0.7-0.9 \mathrm{~mm}$ long; female flowers 3-4 in each umbel, perianth lobes 6, elliptic, 1.7-1.8 $\times 0.9-1.2 \mathrm{~mm}$, sparsely hairy, 
ovary ovoid, $0.8-1 \mathrm{~mm}$ in diameter, glabrous, style $0.9-1 \mathrm{~mm}$ long, stigma peltate. Fruits globose, 3.8-12.5 × 3.4-10 mm, smooth, glabrous, dark red when mature; cupule shallow, 4.3-7 × 1.7-3.6 mm, lobed, membranous, perianth lobes 1.1-1.5 $\times$ 0.5-0.6 mm long, apex acute to acuminate; stalk 0-2 $\times 1-1.2 \mathrm{~mm}$, not swollen.

Distribution. Peninsular Malaysia and Borneo (see Fig. 23).

Ecology. Growing in lowland to montane forests, at 60-1500 m altitude. Flowering from February to June; fruiting from February to December.

Vernacular name. Kayu kletayo (Temuan).

Provisional IUCN conservation assessment. This species is known from at least 15 localities and has a relatively large extent of occurrence (EOO of 394,096 $\mathrm{km}^{2}$ ) but a relatively small area of occupancy (AOO of $60 \mathrm{~km}^{2}$ ). Given the large extent of occurrence and the large number of known localities, despite the relatively small AOO, an assessment of globally Least Concern is proposed.

Specimens examined. PENINSULAR MALAYSIA: Penang: s.l., Mar 1915, Ridley s.n. (BM); Western Hill, 7 Apr 1923, Haniff SFN 9131 (KEP); Moniot Road, Mar 1886, Curtis 649 (BM). Perak: Kledang Saiong, 22 Apr 1931, Symington KEP 25567 (KEP); ibidem, 12 Feb 1934, Saw 33681 (KEP); Sungai Panchor, 16 Feb 1972, Whitmore FRI 20567 (KEP). Kelantan: Ulu Sungai Ketil, 16 Mar 1972, Mhd Shah MS 2577 (KEP). Pahang: Lesong F.R., 11 Jun 1979, Chan FRI 23902 (KEP); Gunung Lesong, 25 Nov 1973, Mhd Shah \& Skukor MS 3121 (KEP); Gunung Aais Forest, 5 Jul 2004, Chung RC 119 (KEP); Krau Game Reserve, 16 Mar 1967, Whitmore FRI 3227 (KEP). Selangor: Ulu Langat, 20 Nov 1960, Gadoh anak Umbai KL 2225 (KEP); Bukit Tanggas, 1 Dec 1903, Nur SFN 11807 (K); Bukit Langat, 18 Sep 1969, Suppiah FRI 11439 (KEP). Negeri Sembilan: Gunung Angsi, 21 Nov 1923, Nur SFN 11575 (KEP). Johor: Labis, 19 Feb 1971, Samsuri \& Shukor SA 493 (KEP); Gunung Blumut, 23 Sep 1970, Mhd Shah \& Sanusi MS 2119 (KEP); ibidem, 23 Sep 1970, Mhd Shah \& Sanusi MS 2138 (KEP [2 sheets]); Mersing, Endau-Rompin, 6 Jul 2012, Kamarul Hisham FRI 73827 (KEP).

Notes. In his revision of the species of Borneo, $\mathrm{Ng}$ (2005) divided Litsea sessiliflora into two varieties. The type variety was said to differ from the Bornean endemic Litsea sessiliflora var. othmanii $\mathrm{Ng}$ by the latter having leaves with minute appressed hairs on the lower surface of the blade (whereas the type variety is sparsely hairy to velutinous on the veins on the lower surface of the blade), and its leaves are $1.5-4.5 \mathrm{~cm}$ wide (whereas in the type variety the blades are $3-9.5 \mathrm{~cm}$ wide). This Bornean variety also has anthers which can have either two or four cells, crossing the generic boundary between Litsea and Lindera.

In the original description of Litsea sessiliflora (Hooker, 1886: 160), only one gathering was mentioned: Maingay s.n. [Kew distribution no. 1511]. Three specimens of this gathering were found, two at K [K000229422 \& no barcode] and one at BM [no barcode]). One of the K sheets [K000229422] is designated here as the lectotype. 


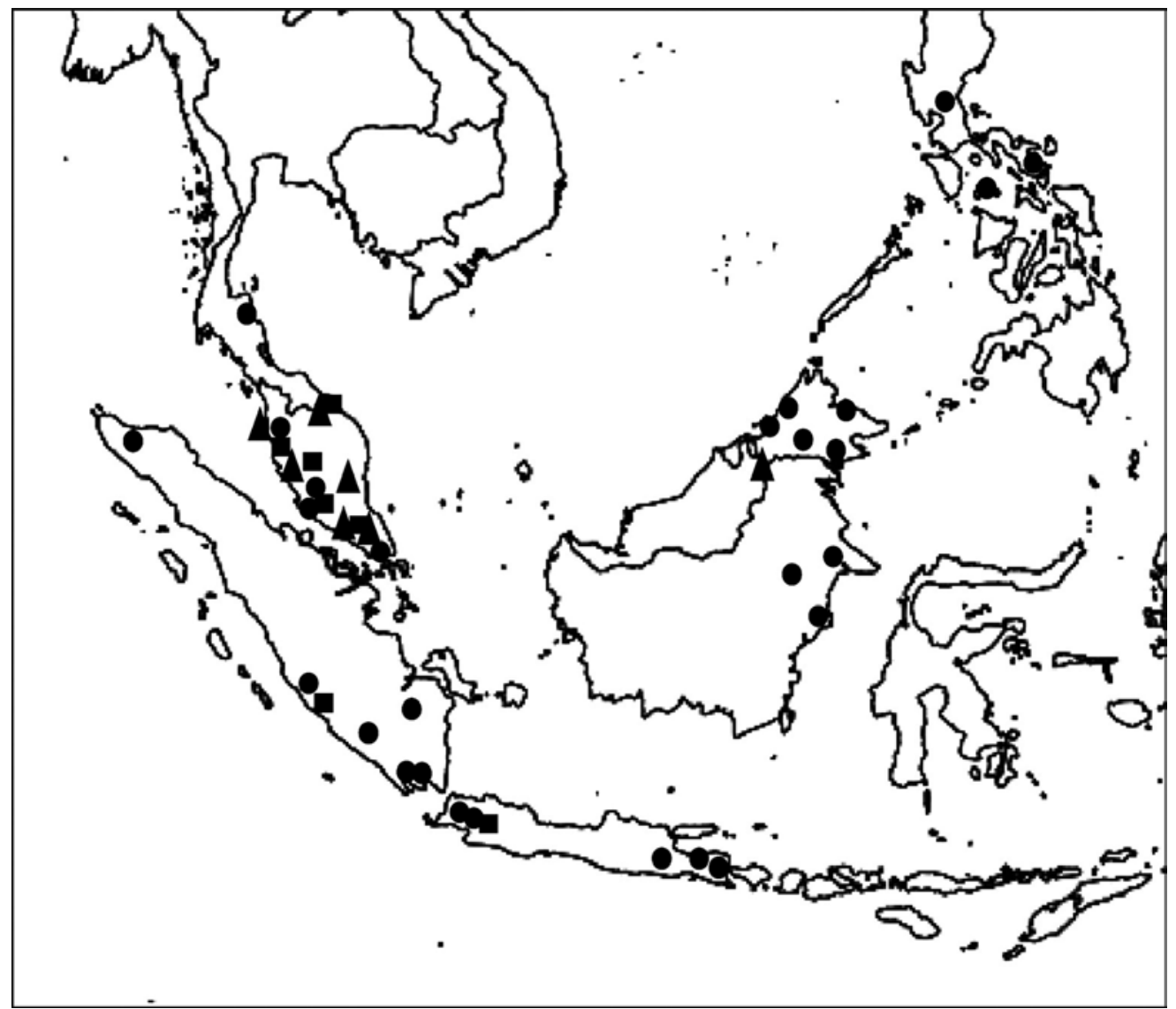

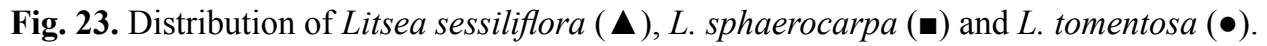

In the original description of Litsea ujongensis (Gamble, 1910b: 366), several gatherings were mentioned: Ridley's Collectors 1904, 1942, 2305, 2316, 5846, 5848 and Ridley 3172. Of all these gatherings, only one specimen, of Cantley 5848 [K000797132], could be found and it is designated here as the lectotype.

In the original description of Litsea ujongensis var. nervosa (Gamble, 1910b: 366) only two gatherings were mentioned: Wray 1129 and Scortechini 2097. Of these, the K specimen of Scortechini 2097 is sterile, while the Wray 1129 specimen at K [K000797134] has the characteristic card with drawings and dissections made by Gamble. This latter specimen is designated here as the lectotype.

35. Litsea sphaerocarpa Blume, Bijdr. Fl. Ned. Ind. 11: 559 (1826). - Actinodaphne sphaerocarpa (Blume) Nees, Syst. Laur. 605 (1836); Kochummen in Ng, Tree F1. Malaya 4: 108 (1989). - Jozoste sphaerocarpa (Blume) Kuntze, Revis. Gen. P1. 2: 570 (1891). - TYPE: [Indonesia, Java], Parang, Blume s.n. (lectotype L [L0035503], designated here). 
Litsea spathacea Gamble, Bull. Misc. Inform. Kew 1910: 358 (1910), syn. nov.; Ridley, Fl. Malay Penins. 3: 120 (1924); Kochummen in Ng, Tree Fl. Malaya. 4: 165 (1989). - TYPE: [Peninsular Malaysia], Perak, Sungai Larut, July 1988, Wray 2286(lectotype K [K000797118], designated here; isolectotype SING [SING0229222]).

Litsea spathacea Gamble var. tomentosa Gamble, J. Asiat. Soc. Bengal, Pt. 2, Nat. Hist. 75: 152 (1912); Ridley, Fl. Malay Penins. 3: 119 (1924). - TYPE: [Peninsular Malaysia], Perak, Ulu Selama, September 1884, Scortechini 1289 (lectotype K [K000797113], designated here; isolectotypes BM [BM000799152], K [no barcode]).

Tree or shrub 4.5-15 m tall; dbh 7-30 cm. Twigs slender to stout, $2.7-9 \mathrm{~mm}$ thick, grey, rarely brown, angled to round in cross-section, densely hairy when young, glabrescent; hairs appressed, yellowish; terminal leaf bud lanceolate to ovate, 2-6.3 $\mathrm{mm}$ long, apex acute, velutinous. Leaves alternate; leaf blade membranous to thinly leathery, elliptic to oblanceolate or obovate, $11-29 \times 4-12 \mathrm{~cm}$, apex obtuse to acute, base cuneate; secondary veins 9-14 pairs, curving near the margin and sometimes brochidodromous; tertiary veins scalariform-reticulate; surface above glossy, dark green, glabrous with a few hairs on midrib, midrib sunken, secondary veins raised, tertiary veins distinct; surface below green with yellowish midrib, glaucous, glabrous to sparsely hairy, always with some hairs present on midrib, midrib and secondary veins raised, tertiary veins distinct; petiole half-terete, $10-25 \mathrm{~mm}$ long, slender to slightly swollen, sparsely hairy. Inflorescences clusters of umbels $1-4 \mathrm{~cm}$ long, borne in axils of leaves or along branchlets, umbels 6-7.5 $\mathrm{mm}$ in diameter, pale yellow-green or greenish white; bracts 5, usually imbricate, (sub)orbicular, concave, 5-6.5 $\times 5-6$ $\mathrm{mm}$, velutinous outside; infructescence with 1-3 fruits. Flowers white; male flowers 6-8 in each umbel, perianth lobes 5-6, elliptic-lanceolate, $1.5-4 \times 0.8-1 \mathrm{~mm}$, hairy, stamens 8-14, unequal, 1-5 mm long, with a few hairs present, anthers $0.5-1.5 \mathrm{~mm}$ long, yellow; female flowers 3-6 in each umbel, perianth lobes 5-6, elliptic-lanceolate, 2-3 $\times 0.9-3 \mathrm{~mm}$, sparsely hairy, ovary ovoid, $0.5-1 \mathrm{~mm}$ in diameter, glabrous, style 1-2 mm long, stigma peltate. Fruits globose to elliptic, 15-20 × 11-14 mm, apex acute, smooth, densely hairy to glabrous, red or purplish when mature; cupule shallow, $13-15 \mathrm{~mm}$ in diameter, 5-7.2 $\mathrm{mm}$ high, glabrous, margins entire or undulate, surface smooth, white; stalk slightly thickened, $1.7-2.6 \mathrm{~mm}$ thick, 5-10 $\mathrm{mm}$ long, densely to sparsely hairy.

Distribution. Peninsular Malaysia, Singapore, Sumatra and Java (see Fig. 23).

Ecology. Growing in lowland and hill forests, sometimes along rivers, from 90-975 m altitude. Flowering all year round; fruiting from February to March.

Vernacular names. Pokô julutong (Malay); Medang sunyi, Medang daun puteh, Klaber (Temuan). 
Provisional IUCN conservation assessment. This species is known from at least 20 localities and has a relatively large extent of occurrence (EOO of 67,341 $\mathrm{km}^{2}$ ) and area of occupancy (AOO of $56 \mathrm{~km}^{2}$ ). It occurs in various types of forests and is reported to be common where it occurs. Therefore, an assessment of globally Least Concern is proposed.

Specimens examined. PENINSULAR MALAYSIA: Penang: Pulau Penang, Oct 1894, Curtis Collector s.n. (SING [2 sheets]). Perak: s.l., Jul 1900, Ridley s.n. (SING); Tapah Hill, 12 Jul 1966, Ng FRI 1341 (KEP, SING); Larut, Oct 1882, King's Collector 3493 (K); ibidem, Nov 1882, King's Collector 5130 (K, P); ibidem, Dec 1883, King's Collector 5280 (MEL); Relan Tujor, Jun 1888, Wray 2198 (SING); Maxwell's Hill, Wray 2198 (SING); ibidem, Aug 1888, Wray 2755 (K); ibidem, Oct 1884, Scortechini 1410 (K). Kelantan: Sungai Jenal, 27 Oct 1967, Cockburn FRI 7447 (KEP, SING). Pahang: s.1., 4 Nov 1924, Haniff 16488 (K, SING); Beserah, 6 Dec 1924, Haniff 17582 (SING); Pekin, 14 Feb 1929, Jaamat 16503 (KEP, SING); Raub, 12 Oct 1929, Ismail 20301 (KEP, SING); Hutan Simpan, 14 Mar 1986, Teo \& David KL 3485 (K, SING); Ulu Sungai Punkin Lesong, 16 Feb 1971, Ahmad \& Shukor SA 415 (KEP, SING); Jenka, 14 Mar 1989, Damahuri FRI 36587 (KEP). Selangor: Bukit Inung, 7 Mar 1959, Gadoh anak Umbai KL 1442 (KEP, SING [4 sheets]); Bukit Lagong, 24 Sep 1980, Kochummen FRI 29120 (KEP); ibidem, 12 Jan 1979, Suppiah FRI 28247 (KEP); Ulu Langat, 10 Jan 1959, Gadoh anak Umbai KL 1280 (KEP, SING [2 sheets]), KL 1245 (KEP, SING); ibidem, 4 Sep 1960, Gadoh anak Umbai KL 2176 (KEP); Bukit Lagong, 1 Nov 1953, Sinclair SFN 40097 (BM, KEP, SING); Bukit Inu, Ulu Langat, 6 Sep 1958, Gadoh anak Umbai KL 855 (KEP); Semenyih, 30 Jul 1921, Hume 8375 (SING); Ulu Gombak, 21 Jul 1921, Hume 9841 (SING); Kepong, 15 Jan 1932, Fachun 27699 (KEP). Kuala Lumpur: s.l., Feb 1890, Curtis 2371 (SING); Weld Hill, 1 Nov 1916, Hamid 860 (KEP); ibidem, Forest Dept. s.n. (SING). Negeri Sembilan: Bukit Klau, 7 Mar 1885, Alvins 889 [934] (SING); Sungai Ujong, 15 Nov 1885, Alvins 2226 (SING); Bukit Tanjung, 15 Nov 1885, Alvins 2229 (SING); Gunung Tampin, 27 Jan 1918, Burkill 3099 (K, SING); Bukit Tangga, Dec 1920, Ridley s.n. (SING). Johor: Bukit Badak, 27 Jan 1959, Hassan \& Kadim H 72 (SING); Gunung Ledang, 13 Jul 1969, Whitmore FRI 12283 (KEP).

Notes. The name Litsea sphaerocarpa Blume was moved to Actinodaphne Nees by Nees von Esenbeck (1836: 305) in his species dubiae, but without a reason given. Kochummen (1989: 108) accepted this, but he stated that he had not seen any type material and that the leaf arrangement was unusual for an Actinodaphne. Having seen type material, I have moved the name back to Litsea.

In the original description of Litsea sphaerocarpa (Blume, 1826: 559), the only data given are that it was collected from Parang in montane forest [sylvis montium] and that it has the local name 'Huru paying alus'. Of the six Blume specimens [L0035501, L0035502, L0035503, L0035504, L0035505, L0035506] available for lectotypification, only three [L0035501, L0035503, L0035505] mention the locality. Of these only one specimen has an infructescence and a fruit [L0035503] and is designated here as the lectotype.

Several gatherings were mentioned in the protologue of Litsea spathacea by Gamble (1910b: 358): Wray 2198, 2286, 2755; Scortechini 1410; King's Collector 3493, 4971, 5130, 5280 and Curtis 2371. Of these no specimens of the gatherings 
King's Collector 4971 could be found. The K specimen of Wray 2286 [K000797118] is designated here as the lectotype.

Only one gathering was mentioned in the original description of Litsea spathacea var. tomentosa (Gamble, 1912: 152): Scortechini 1289, of which there are several specimens at various herbaria. The K specimens all have flowers, but the one with more inflorescences [K000797113] is designated here as the lectotype.

36. Litsea tomentosa Blume, Bijdr. Fl. Ned. Ind. 11: 566 (1826); Gamble, J. Asiat. Soc. Bengal, Pt. 2, Nat. Hist. 75: 132 (1912); Ridley, Fl. Malay Penins. 3: 115 (1924); Backer \& Bakhuizen van den Brink, Fl. Java (Spermatoph.) 1: 125 (1963); Kochummen in Ng, Tree Fl. Malaya 4: 165 (1989); Ngernsaengsaruay et al., Thai Forest Bull., Bot. 39: 90 (2011). - TYPE: [Indonesia], Java, Blume s.n. (lectotype K [K000815822], designated by Ngernsaengsaruay et al., Thai Forest Bull., Bot. 39: 90 (2011)).

Tree 6-40 m tall, dbh 7-40 cm, buttresses extending $60 \mathrm{~cm}$ outwards; bark smooth, lenticellate, greyish or light brown to black, inner bark red-brown, sapwood yellow. Twigs slender to stout, 3.8-12 mm thick, round or angular in cross-section, velutinous, glabrescent; hairs appressed to patent, yellowish; terminal leaf bud ovate, 5.5-8.3 $\mathrm{mm}$ long, apex acuminate, velutinous. Leaves spirally arranged, crowded towards the apex of branchlets; leaf blade chartaceous, elliptic to oblanceolate, 8-40 $84-16 \mathrm{~cm}$, apex obtuse to acute, base cuneate to rarely rounded, sometimes asymmetric, margins straight; secondary veins 11-16 pairs, curving and sometimes brochidodromous; tertiary veins scalariform-finely reticulate; surface above glabrous, green with densely hairy midrib and secondary veins, midrib raised to sunken, secondary veins shallowly sunken, tertiary veins faint; surface below glaucous, sparsely to densely yellowish hairy on major veins, midrib and secondary veins raised, tertiary veins distinct; petiole halfterete, $10-55 \mathrm{~mm}$ long, velutinous (hairs appressed to patent, yellowish), glabrescent. Inflorescences clusters of umbels, $1.5-3 \mathrm{~cm}$ long, borne along branchlets, velutinous, umbels $12-20 \mathrm{~cm}$ in diameter; bracts 4-5, suborbicular or broadly ovate, concave, 5-6 $\times 4-5 \mathrm{~mm}$, velutinous. Flowers: male flowers 5-6 in each umbel, perianth lobes 9-12, lanceolate, unequal, 4-6 × 1.5-2 mm, sparsely hairy, stamens 24-30, unequal, 2-5 $\mathrm{mm}$ long, sparsely hairy, anthers $1-1.5 \mathrm{~mm}$ long; female flowers $5-6$ in each umbel, perianth lobes $8-12$, lanceolate, $2-3.1 \times 1-1.3 \mathrm{~mm}$, densely hairy, ovary ovoid, $1-1.5$ $\mathrm{mm}$ in diameter, glabrous, style 1.5-2 mm long, stigma peltate. Fruits (sub)globose, 16-22 $\times 20-21 \mathrm{~mm}$, smooth, glabrous, glossy, red when mature; cupule shallow, 11$15 \times 1.5-3 \mathrm{~mm}$, sparsely hairy, margins entire, surface warty; fruiting pedicels 7-9.6 $\mathrm{mm}$ long, $4.3-5.8 \mathrm{~mm}$ thick, sparsely hairy; stalk $2-10 \mathrm{~mm}$ long, sparsely hairy.

Distribution. Peninsular Thailand, Peninsular Malaysia, Singapore, Sumatra, Borneo, Java and Philippines (see Fig. 23). 
Ecology. Open areas in disturbed rain forests, at 600-750 m altitude. Flowering from February to June; fruiting from September to January.

Vernacular name. Medang taudok (Malay).

Provisional IUCN conservation assessment. This species is known from about 100 localities in total and has a very large extent of occurrence (EOO of 4,638,566 $\mathrm{km}^{2}$ ) and area of occupancy (AOO of $144 \mathrm{~km}^{2}$ ). Given these factors, and the fact that this species can grow in secondary vegetation, an assessment of globally Least Concern is proposed.

Specimens examined. PENINSULAR MALAYSIA: Penang: s.l., Curtis s.n. (BM); West Hill Road, May 1887, Curtis 1182 (K, SING); ibidem, Apr 1890, Curtis 1182 (SING). Pahang: Gunung Benom Game Reserve, 23 Apr 1967, Ismail KEP 100108 (KEP, SING). Selangor: Sungai Buloh, 31 Mar 1967, Kochummen FRI 2274 (KEP); Bukit Damansara, 5 Nov 1908, Hoskim 734 (KEP); Genting Highlands Road, 5 Jan 1972, Kochummen FRI 16451 (KEP); Sungai Balok Reserve, 13 Feb 1923, Kiai 8269 (KEP, SING). Kuala Lumpur: Damascus Road, 1900, Ridley s.n. (SING); Weld Hill Reserves, 10 May 1917, Curtis's Collector 975 (K, KEP, SING).

SINGAPORE: Upper Tanglin, behind barracks, 1893, Ridley s.n. (SING).

Notes. Vegetative specimens of this species look superficially very like Actinodaphne macrophylla (Blume) Nees, but can be distinguished from the latter by their large terminal leaf buds, or the scars on the twigs, and a dark brown indumentum.

37. Litsea umbellata (Lour.) Merr., Philipp. J. Sci. 14: 242 (1919); Corner, Wayside Trees Mal. 347 (1940); Kochummen in Ng, Tree Fl. Malaya. 4: 166 (1989); Ng, Gard. Bull. Singapore 57: 234 (2005); Ngernsaengsaruay et al., Thai Forest Bull., Bot. 39: 91 (2011). - Hexanthus umbellatus Lour., Fl. Cochinch. 1: 196 (1790). - Litsea hexantha [Juss., Ann. Mus. Natl. Hist. Nat. 6: 212 (1805), nom. inval.] Pers., Syn. Pl. 2(1): 4 (1806), as 'hexanthus', nom. illeg. - TYPE: Cochinchina [Vietnam], Loureiro s.n. (lectotype BM [BM000951060], designated by De Kok, Gard. Bull. Singapore 69: 176 (2017); isolectotype BM [BM000951061]). (Fig. 24).

Litsea amara Blume, Bijdr. Fl. Ned. Ind. 11: 563 (1826); Ridley, J. Straits Branch Roy. Asiat. Soc. 33: 131 (1900); Lecomte, Nouv. Arch. Mus. Hist. Nat., ser. 5, 5: 90 (1913); Lecomte, Fl. Indo-Chine 5: 136 (1914); Ridley, Fl. Malay Penins. 3: 117 (1924); Liou Ho, Laurac. Chine \& Indochine 190 (1932); Backer \& Bakhuizen van den Brink, Fl. Java (Spermatoph.) 1: 126 (1963). - Tetranthera amara (Blume) Nees in Wallich, P1. Asiat. Rar. 3: 30 (1832); Nees, Syst. Laur. 551 (1836); Blume, Mus. Bot. 1: 379 (1851); Meisner in DC., Prodr. 15: 190 (1864). - TYPE: [Indonesia, Java], in mountains, Blume s.n. (lectotype L [L0308989], designated here; isolectotype L [L0308990 \& L0308992]). 
Tetranthera angusta Nees in Wallich, Pl. Asiat. Rar. 3: 30 (1832); Kochummen in Ng, Tree Fl. Malaya. 4: 166 (1989). - Litsea amara Blume var. angusta (Nees) Meisn. in DC., Prod. 15: 190 (1864); Ridley, Fl. Malay Penins. 3: 117 (1924). TYPE: [Myanmar], Syriam/Pegu, 1826, Wallich s.n. [EIC 6344b] (lectotype K-W [K001123633], designated here; isolectotypes BM [no barcode], K [K001123634]).

Tetranthera firma Blume, Mus. Bot. 1: 381 (1851), syn. nov.; Meisner in DC., Prodr. 15: 190 (1864) 190; Ng, Gard. Bull. Singapore 57: 230 (2005). - Litsea firma (Blume) Hook.f., Fl. Brit. India 5: 162 (1886); Ridley, Fl. Malay Penins. 3: 116 (1924); Corner, Wayside Trees Mal. 347 (1940); Kochummen in Ng, Tree Fl. Malaya 4: 156 (1989); Keng, Concise Fl. Singapore, vol. 1, Gymn. Dicot. 19 (1990); Ng, Gard. Bull. Singapore 57: 230 (2005); Ngernsaengsaruay et al., Thai Forest Bull., Bot. 39: 53 (2011). - TYPE: [Borneo], Korthals s.n. (lectotype BO [sheet no. BO-1245463], designated by Ng, Gard. Bull. Singapore 57: 230 (2005)).

Litsea gracilis Gamble, Bull. Misc. Inform. Kew 1910: 317 (1910); Ridley, Fl. Malay Penins. 3: 117 (1924); Kochummen in Ng, Tree Fl. Malaya. 4: 158 (1989); Ng, Gard. Bull. Singapore 57: 242 (2005). - TYPE: [Peninsular Malaysia], Perak, Ulu Temango, July 1909, Ridley 14603 (lectotype K [K000797038], designated by De Kok, Gard. Bull. Singapore 69: 173 (2017); isolectotypes K [K000797039], SING [SING0055927]).

Litsea cylindrocarpa Gamble, Bull. Misc. Inform. Kew 1910: 318 (1910); Ridley, Fl. Malay Penins. 3: 121 (1924); Ng, Gard. Bull. Singapore 57: 230 (2005). - TYPE: [Peninsular Malaysia], Perak, Larut, October 1884, King's Collector 6673 (lectotype SING [SING0054672], designated by Ng, Gard. Bull. Singapore 57: 230 (2005); isolectotypes K [K000797096], KEP [80760], L [L0036664]).

Litsea amara Blume var. attenuatta Gamble, J. Asiat. Soc. Bengal, Pt. 2, Nat. Hist. 75: 142 (1912); Ridley, Fl. Malay Penins. 3: 117 (1924); Kochummen in Ng, Tree Fl. Malaya. 4: 166 (1989). - TYPE: [Peninsular Malaysia], Malacca, Batu Tiga, 1892, Derry 990 (lectotype K [K000797034], designated by De Kok, Gard. Bull. Singapore 69: 173 (2017); isolectotypes BM [no barcode], SING [SING0229216]).

Litsea cinerascens Ridl., J. Linn. Soc., Bot. 41: 296(1913), syn. nov.; Ridley, Fl. Malay Penins. 3: 118 (1924); Kochummen in Ng, Tree Fl. Malaya 4: 153 (1989). - TYPE: [Peninsular Malaysia], Pahang, Telom, November 1908, Ridley 13781 (lectotype SING [SING0055903], designated here; isolectotype BM [BM001209836]).

Litsea sp. '3', Kochummen in Ng, Tree Fl. Malaya. 4: 167 (1989).

Litsea salicifolia auct. non (Roxb. ex Nees) Hook.f.: Ridley, J. Straits Branch Roy. Asiat. Soc. 33: 132 (1900). 


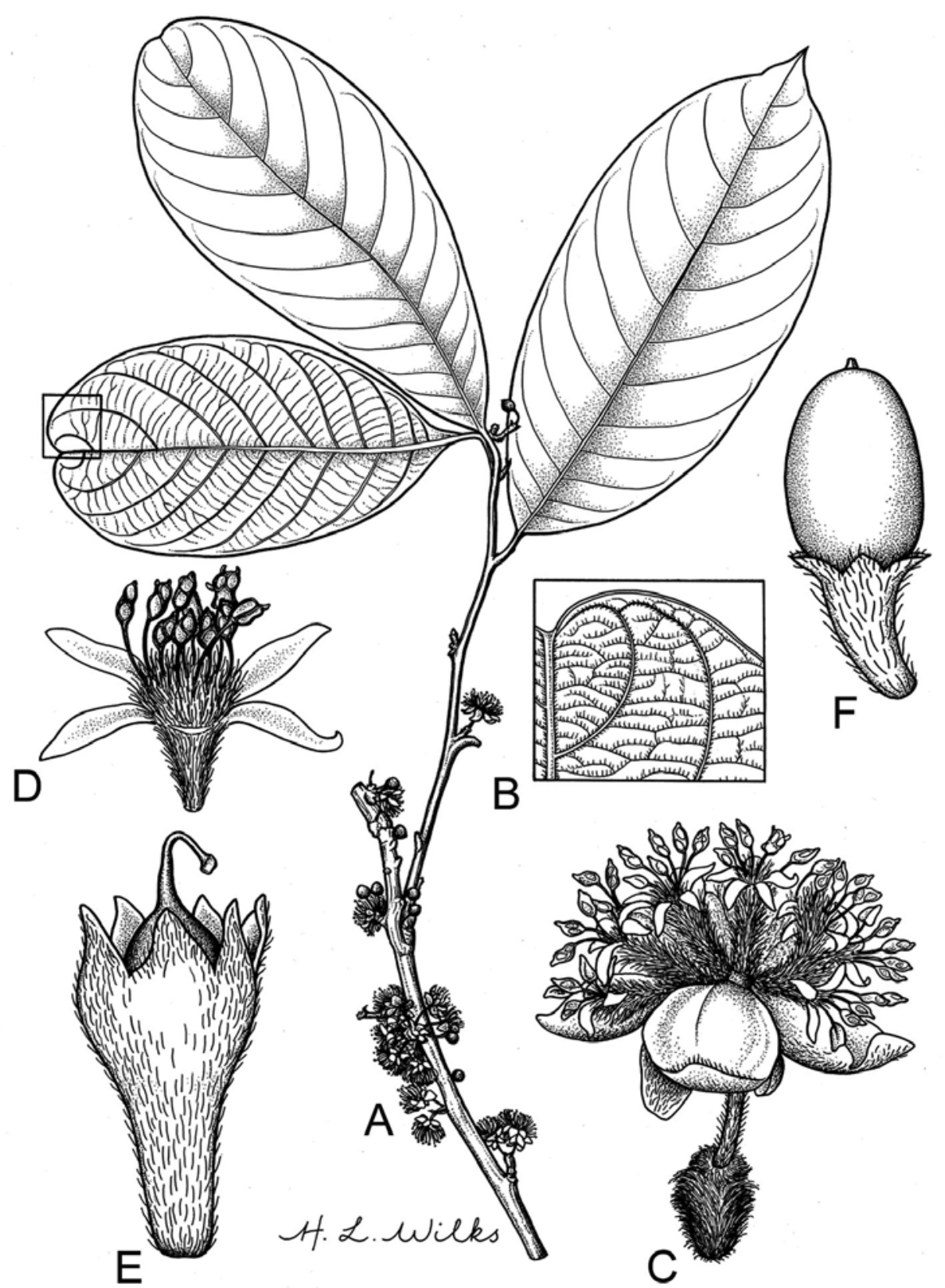

Fig. 24. Litsea umbellata (Lour.) Merr. A. Portion of leafy twig with male inflorescences in clusters of umbels. B. Detail of lower leaf surface. C. Inflorescence with male flowers. D. Open male flower. E. Female flower. F. Fruit with perianth cup and stalk. From Peninsular Malaysia, Larut; A-E from King's Collector 7626; F from King's Collector 2584. Drawn by H. Wilks. 
Tree or shrub, 1-42 m tall, dbh 4-80 cm, trunk sometimes with buttresses to $2.5 \mathrm{~m}$ high; bark smooth to scaly or dippled, lenticellate, pale to dark brown or yellowish grey or reddish brown, inner bark yellow to brownish, sapwood yellow to white, aromatic. Twigs slender, 1.5-4.4 $\mathrm{mm}$ thick, rounded to angular in cross-section, densely hairy to velutinous; hairs appressed to curly, yellowish to reddish brown; terminal leaf bud ovoid to lanceolate, 3-12 mm long, apex acute, velutinous. Leaves alternate, pleasantly scented when crushed; leaf blade papery to thinly leathery, elliptic to obovate or (narrowly) (ob)lanceolate, 3-20 × 1.2-7.5 cm, apex acute to rounded, sometimes acuminate, base rounded to cuneate, sometimes oblique, margins straight, often reddish brown when dry; secondary veins $5-17$ pairs, curving towards the margin at $45-90^{\circ}$ angle at base with midrib; tertiary veins scalariform-reticulate; surface above (dark) green to bluish green, glabrous, midrib and secondary veins very sparsely to densely hairy, midrib and secondary veins sunken to flattened, tertiary veins distinct to indistinct; surface below glaucous, pale green, sparsely hairy, indumentum denser on and along the midrib and secondary veins (hairs appressed to erect, yellowish), midrib and secondary veins raised, tertiary veins distinct; petiole half-terete, 2-23 mm long, slender to slightly swollen, velutinous to sparsely hairy (hairs appressed to erect, long, yellowish to light brown). Inflorescences clusters of umbels, $0.1-2 \mathrm{~cm}$ long, borne in axils of leaves or along branchlets; umbels $3-4.5 \mathrm{~mm}$ in diameter; bracts 4-5, usually imbricate, suborbicular, concave, $2-4.5 \times 2-4 \mathrm{~mm}$, sparsely to densely hairy outside, glabrous inside, greenish white; infructescence with 1-3 fruits. Flowers pale green to white or yellowish, sweetly scented; male flowers 3-8 in each umbel, perianth lobes 5-6, elliptic or elliptic-lanceolate, $1.5-3.8 \times 0.5-1.2 \mathrm{~mm}$, hairy, stamens cream to (bright) yellow, 8-14, unequal, $1-5 \mathrm{~mm}$ long, sparsely hairy, anthers $0.5-1.5$ $\mathrm{mm}$ long, yellow; female flowers 3-6 in each umbel, perianth lobes 5-6, elliptic to elliptic-lanceolate, $1-2.8 \times 0.4-0.8 \mathrm{~mm}$, sparsely hairy, ovary globose or ovoid, $0.5-$ $1.3 \mathrm{~mm}$ in diameter, glabrous, style $1-3.5 \mathrm{~mm}$ long, stigma peltate. Fruits elliptic or (sub)globose, 2.5-10 × 0.6-2 mm, apex rounded, smooth, glabrous, dark red-purple or black when mature, glossy; cupule shallow, 3-8 $\mathrm{mm}$ in diameter, $1.4-3.6 \mathrm{~mm}$ high, sparsely hairy, margins entire, sparsely hairy; stalk $2-10 \times 3.5-3.6 \mathrm{~mm}$, sparsely hairy.

Distribution. South China, Myanmar, Thailand, Cambodia, Laos, Vietnam, Peninsular Malaysia, Singapore, Sumatra, Borneo, Java, Sulawesi, Moluccas, Philippines and New Guinea (Fig. 25).

Ecology. Growing in lowland primary and secondary forests and in open vegetation, sometimes on peaty soils, from $0-1200 \mathrm{~m}$ altitude. Flowering from January to November; fruiting from May to December.

Vernacular names. Pokô medang busuh, Pokô kupong sûgah, usuh, Pokol turusek, Medang wangi hitam, Medang telo (Malay); Isop nanah (Tumpat); Medang bekul, Kayu pagar anak (Temuan); Hairy medang (Singapore).

Provisional IUCN conservation assessment. This species is known from at least 500 localities and has a very large extent of occurrence (EOO of 14,370,505 $\mathrm{km}^{2}$ ) and 


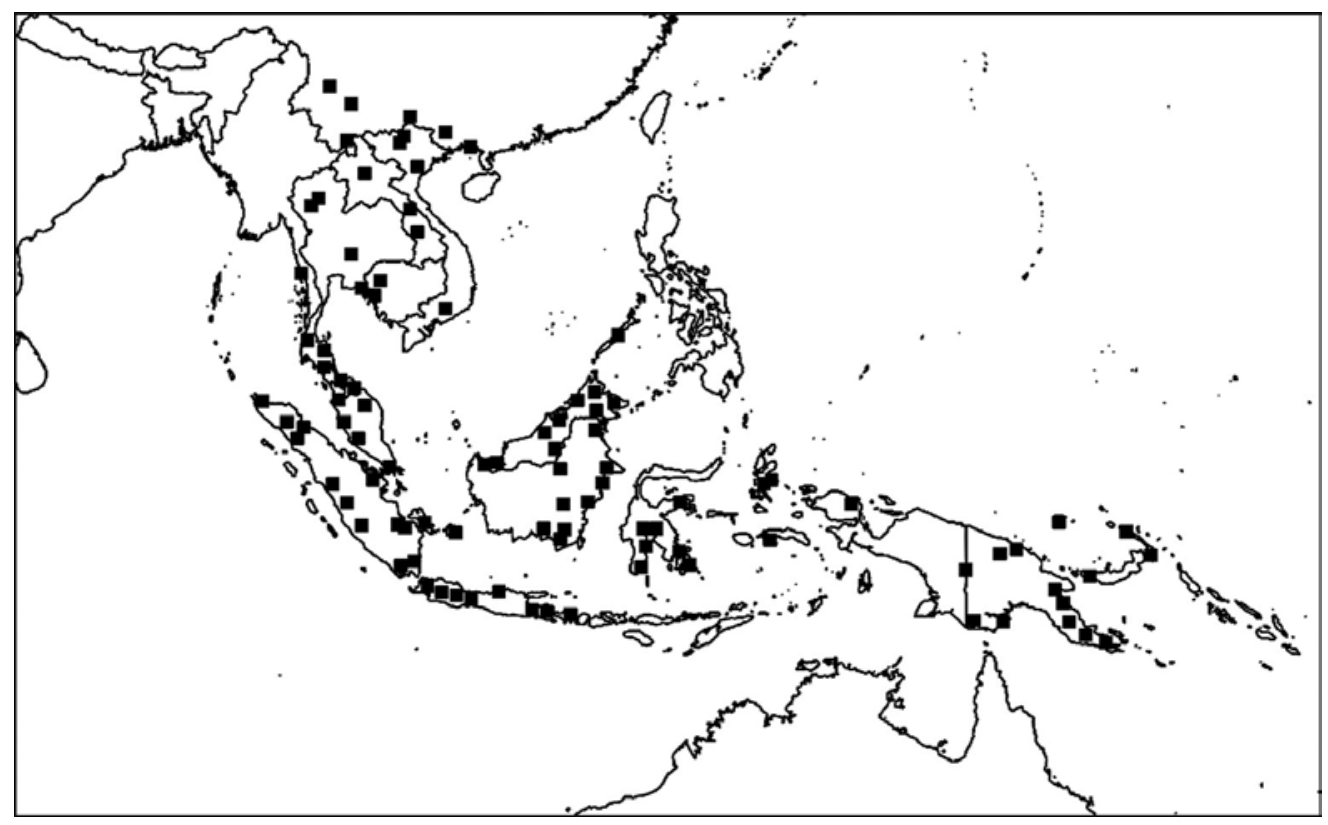

Fig. 25. Distribution of L. umbellata (๘).

area of occupancy (AOO of $1140 \mathrm{~km}^{2}$ ). Given these facts, and its ability to grow in secondary vegetation, an assessment of globally Least Concern is proposed.

Specimens examined. PENINSULAR MALAYSIA: Perlis: Kaki Bukit, 15 Apr 1938, Kiah SFN 35297 (BM, KEP, SING). Kedah: Langkawi, Curtis s.n. (BM); ibidem, Apr 1910, Ridley 15697 (BM, SING); ibidem, Apr 1911, Ridley 15810 (BM, SING); ibidem, Sep 1890, Curtis 2616 (SING [2 sheets]); ibidem, Jan 1897, Ridley 8349 (SING); ibidem, 2 Nov 1900, Ridley 14965 (SING); Alor Setar, Feb 1910, Ridley 15186 (SING); Gunung Lang, 24 Mar 1938, Kiah SFN 35027 (SING [2 sheets]). Penang: s.l., Curtis s.n. (BM, SING); s.1., 1888, Curtis 326 (SING); s.l., Jul 1893, Curtis 733 (SING); s.l., Mar 1886, Curtis 733 (SING); s.l., Apr 1893, Curtis 733 (SING); Ile Poulo Pinang, 1823, Unknown s.n. (BM); Jelok Balacy, 1906, Ridley 12684 (BM); Batik Pulau, Jun 1898, Ridley 9340 (BM); Government Hill, Mar, Curtis 1458 (SING); ibidem, Mar 1890, Curtis s.n. (SING); ibidem, Dec 1886, Curtis 1073 (SING); ibidem, Oct 1884, Curtis 1386 (SING); ibidem, 9 Jul 1889, Ridley 415 (SING); ibidem, Oct 1886, Curtis 1073 (SING); Rifle Range, 5 Jun 1928, Haniff SFN 3720 (SING). Perak: Upper Perak, Wray 3559 (SING [2 sheets]); Fuango, Jul 1909, Ridley s.n. (SING); Dindings, Feb 1892, Ridley s.n. (SING); ibidem, Jul 1885, King's Collector 7859 (BM); Larut, Jun 1884, King's Collector 6207 (BM); ibidem, Jan 1884, King's Collector 5500 (KEP); ibidem, May 1885, King's Collector 7626 (BM); ibidem, 1882, King's Collector 3585 (BM); ibidem, Oct 1886, King's Collector 6772 (BM); ibidem, Jul 1881, King's Collector 2040 (BM); ibidem, King's Collector 2584 (K); Larut, Goping, Jul 1883, King's Collector 4614 (BM); ibidem, May 1882, King's Collector 3033 (SING); Gunung Bubu, 16 Aug 1966, Chew CWL 1208 (KEP); Gunung Ijuk, Sep 1884, Scortechini s.n. (BM); Sungai Kenering, 15 Jun 1930, Henderson SFN 23886 (BM, SING); road to Fuango, Jul 1909, Ridley 14508 (BM, SING); Tapak, Nov 1908, Ridley 14046 (BM); Ulu Tenayo, Jul 1909, Ridley 14505 (BM, SING); Lumut, 28 Aug 1931, Symington KEP 27849 (SING); Lubole Merbau, 16 Jun 1924, Burkill 13588 (SING); Gunung 
Bujang Malaka, Ipoh, 10 Aug 1959, Allen \& Kadim MK 472 (SING); Bintang Hijau F.R., 28 Jul 1970, Chan FRI 13319 (KEP, SING); Tasek Gelugor, 15 Jun 1921, Burkill 6545 (KEP, SING); Maxwell's Hill, 12 Sep 1949, Sinclair SFN 38698 (BM, SING). Kelantan: Sungai Betis, 16 Jul 1935, Henderson SFN 29707 (KEP, SING); Kemaman, Bukit Kajang, 23 Nov 1935, Corner SFN 30580 (SING); Jeli, Batu Melintang, 13 Jan 2010, Imin FRI 66450 (KEP, SING). Terengganu: Gunung Tebu F.R., 11 Sep 1955, Sinclair et al. SFN 40790 (BM, SING); Budi, 1909, Rostado s.n. (SING). Pahang: Bentong, 8 Nov 1924, Burkill \& Haniff SFN 16611 (SING); Sungai Suipang, 9 Nov 1924, Burkill \& Haniff SFN 16811 (SING); Chikus F.R., 14 Aug 1952, Saari KEP 51579 (KEP, SING); Pekan, 1891, Ridley 2266 (BM); 22 Apr 1919, Lambak 2711 (KEP, SING); Temerloh, 10 Jun 1913, Murdock 161 (SING); ibidem, 19 Apr 1920, Awang Lela 2678 (KEP, SING); ibidem, 2 Oct 1921, Idris 6318 (KEP, SING); Lipis, 18 Jun 1919, Matnong FMS 4037 (KEP, SING); Sungai Nering, Temerloh, 21 Mar 1923, Henderson SFN 10600 (SING); Sabai estate, 29 Jan 1958, Mhd Shah 207 (SING); ibidem, 27 Jan 1958, Mhd Shah 174 (SING); Temerloh, 11 May 2005, Syahrir Farihan FRI 48551 (KEP, SING). Selangor: Kampung Belukar, 13 May 1929, Symington KEP 20130 (KEP, SING); Kepong, 8 May 1937, Corner SFN 33543 (SING); Cameron Highlands, Mt Berembun, Chew CWL 787 (SING); Sungai Buloh, 23 May 1918, Ngah 2412 (SING); Bukit Lagong Reserve, 8 Mar 1919, Go 2292 (KEP, SING). Kuala Lumpur: Weld Hill, 24 May 1917, Hamid 271 (KEP); Jalan Maxwell, 6 Jun 1968, Teo 95 (SING); Ulu Langat, 18 Jan 1959, Gadoh anak Umbai KL 1322 (KEP, SING); ibidem, 6 Oct 1959, Gadoh anak Umbai KL 1819 (KEP, SING); Klang gates, 17 May 1921, Hume 7207 (SING); ibidem, 21 May 1921, Hume 7311 (SING); Bukit Biulang, 30 Mar 1899, Ridley 10545 (SING); Ulu Gombak, 6 May 1966, Carrick JC 1465 (SING); ibidem, 15 Jun 1973, Mhd Shah \& Ali MS 3064 (KEP, SING); Gombak, 31 Mar 2005, Asnah FRI 35566 (KEP, SING); Bukit Lagong F.R., 4 May 1976, Chan FRI 023900 (KEP, SING); Kuala Lumpur, Jan 1908, Haskiu s.n. (BM, SING); Public Gardens, Kuala Lumpur, 29 Sep 1919, Ahmad 4930 (SING); Public Gardens, 5 Aug 1919, Ahmad 4761 (SING); Weld Hill, 11 Apr 1919, Ahmad 3049 (KEP, SING); Weld Hill Reserve, 14 May 1917, Curtis Collector 982 (SING). Negeri Sembilan: Bukit Bertam, 10 Mar 1888, Alvins 1258 (SING); Pantai, 26 Jun 1888, Alvins 2013 (SING); Tampin, Aug 1915, Nur s.n. (SING); Bukit Julio, 2 Nov 1885, Alvins s.n. (SING); Gunung Berembun, 29 Jun 1885, Alvins 1777 (SING). Malacca: Sungai Udang, 1894, Ridley 1593 (BM); ibidem, Jun 1890, Derry 524 (SING); Bukit Tampin, May 1894, Goodenough 1957 (SING); Semenyih, 21 Jul 1921, Hume 8223 (SING); Chabau, 25 Sep 1885, Alvins 2089 (SING). Johor: Tua Rauts, 1890, Ridley 4614 (BM); Kota Tinggi, Mawai Road, 8 Mar 1936, Corner SFN 30788 (KEP, SING); Gunung Blumut, 15 May 1968, Whitmore FRI 8791 (KEP); Gunung Ledang (Mt Ophir), 15 Jul 1969, Whitmore FRI 12338 (KEP); Ma'okil F.R., 15 Jul 1975, Mhd Shah MS 3672 (SING); Segamat, Simpang, 17 Jul 1975, Mhd Shah \& Ahmad MS 3688 (KEP, SING); Berau, Nov 1890, Ridley s.n. (SING).

SINGAPORE: s.l., Cantley s.n. (SING); s.l., Cantley's Collector s.n. (SING); Pulau Ubin, 2 Mar 1893, Ridley 4825 (BM, K, SING); ibidem, Chek Jawa, 5 Nov 2002, Gwee et al. GAT 93 (SING); ibidem, 7 Jan 2003, Gwee et al. GAT 144 (SING); Pasir Ris Farmway 1, 28 May 2013, Lua SING2013-101 (SING); Changi Air Base, 24 Feb 2005, Ganesan et al. SKG 85 (SING); Chua Chu Kang, 1895, Ridley 6820 (BM [2 sheets], K, SING); south side of MacRitchie Reservoir, 7 Aug 1955, Sinclair SFN 40695 (BM, K, KEP, SING); ibidem, 18 Apr 1953, Sinclair s.n. (K); near Bukit Timah, 1894, Ridley 6453 (BM, K, SING); Botanic Garden, 10 Sep 1929, Nur s.n. (BM); ibidem, Gardens' Jungle, 28 Oct 1937, Corner SFN 33700 (K, KEP, SING); ibidem, Arboretum, 10 Sep 1929, Nur s.n. (K [2 sheets]); MacRitchie Reservoir, 7 Dec 1937, Corner SFN 34615 (K, KEP, SING); ibidem, 14 Jul 1976, Mhd Shah \& Ali MS 3915 (KEP, SING); Tanjong Gul, 21 May 1953, Sinclair SFN 39642 (K, SING); Nee Soon Pipeline, 1 Sep 2013, Ali et al. SING2013-236 (SING); Seletar Reservoir, 17 Sep 2013, Ng et 
al. SING2013-210 (SING); Upper Seletar Reservoir, 21 Sep 2013, Lim et al. SING2013-224 (SING); Bukit Timah, 5 Jul 1976, Mhd Shah \& Samsusi MS 3887 (SING); Bukit Timah Village, 19 May 1918, Burkill 2877 (SING); Mandai Road, 1937, Curry s.n. (SING); ibidem, 3 Jan 1937, Corner s.n. (SING); Holland Road, 22 May 1893, Hullett s.n. (SING); Bukit Mandai, 22 May 1900, Ridley 10833 (SING); Bukit Timah Nature Reserve, 15 Aug 1938, Ngadiman SFN 35509 (K, KEP, SING [2 sheets]); ibidem, 18 Jun 1968, Noor MN 113 (SING); ibidem, Jalan Jambul, 22 Apr 1974, Noor MN 1878 (SING); ibidem, 14 Jul 1971, Tambi $H 23$ (KEP, SING); ibidem, 11 Oct 1961, Chew CWL 244 (K, SING); ibidem, 5 Dec 1982, Maxwell 82-298 (SING [2 sheets]); ibidem, 28 Feb 1982, Maxwell 82-61 (SING).

Notes. The name Litsea firma has been lectotypified twice, first by Ng (2005: 230) who selected a specimen collected by Korthals in Borneo and housed in BO [sheet no. BO-1245463], while Ngernsaengsaruay et al. (2011) selected a Bornean specimen of Korthals housed at K [K000815225], with an isolectotype at U [U0002806]). The first lectotypification has priority.

There has been much discussion on how Litsea firma differs from L. umbellata. According to Kochummen (1989: 166), Litsea umbellata has a different growth habit and height and also shorter petioles (5-7 mm long). However, during this current research, this latter difference has proved to be illusionary. In the treatment of the species for Thailand, Ngernsaengsaruay et al. (2011) noted that Litsea umbellata also has a different growth habit and height (shrub to medium-sized tree 1-13 $\mathrm{m}$ tall), short inflorescences $(0.5-1 \mathrm{~cm}$ long) and leaves without scales, while L. firma is a medium-sized or tall tree up to $42 \mathrm{~m}$ tall, with longer inflorescences (1-2 cm long) and twigs and leaves with brown scurfy scales. In this research, no specimens were found with scales, and scales were also not mentioned in the original description of Litsea firma. Inflorescence length was found to be highly dependent on the maturity of the inflorescences and the supposed differences are therefore not upheld. Overall, Litse a firma appears to be the name given to the more robust and taller trees within the total variation of L. umbellata. However, field staff at SING herbarium do differentiate between the two forms based mainly on growth habit, but also on leaf venation. Therefore, more work, in particular using molecular data, is needed to determine the relationship between these forms.

In his treatment of the species, Kochummen (1989: 167) recognised a mountain form (species 3) closely related to Litsea umbellata and differing only in tree size and habit. After seeing numerous specimens of Litsea umbellata, I conclude that this form falls within the general variation of L. umbellata.

In his account in the Tree Flora of Malaya, Kochummen (1989: 158) recognised the species Litsea gracilis, which is only known from its type, and which he claimed at that time not to have seen. However, the isotype in SING bears a later note from him reducing it to synonymy under Litsea umbellata. I agree with this reduction.

Litsea cinerascens Ridl. is only known from its type collection which has very immature inflorescences and no mature flowers or fruits. Comparing the type material with other species of Litsea in Peninsular Malaysia, it is clear that it is a synonym of L. umbellata. In the original description of this species (Ridley, 1913: 296) only one gathering is cited: Ridley 13781. The specimen in SING [SING0055903] is designated here as the lectotype. 
In the original description of Litsea amara Blume (Blume, 1826) only one gathering is cited: in mountains, C.L. Blume s.n. There are three specimens in L [L0308989, L0308990, L0308992] with the correct label information, and the specimen [L0308989] is designated here as the lectotype.

In the original description of Tetranthera angusta Nees (Nees von Esenbeck 1832: 30) two gatherings are cited: Wallich cat 6344, Syrian in Pegu, August 1828 and G. Gomez, Tavoy, September 1827. Only specimens of the first gathering could be found and the specimen [K001123633] is designated here as the lectotype.

\section{Insufficiently known species}

\section{Litsea aff. maingayi}

Tree about $5 \mathrm{~m}$ tall. Twigs slender to stout, 3.5-7.5 mm thick, dark brown, angular to round in cross-section, glabrous; terminal leaf bud 5-9 $\mathrm{mm}$ long, lanceolate, apex acute, velutinous. Leaves alternate; leaf blade leathery, elliptic to oblanceolate, 10-32 $\times 3.5-9 \mathrm{~cm}$, apex acuminate with distinct tip, base cuneate; secondary veins $8-16$ pairs, brochidodromous; tertiary veins scalariform; surface above glabrous, midrib raised to flattened, secondary veins sunken, tertiary veins indistinct; surface below glaucous, glabrous except slightly hairy on midrib, midrib and secondary veins raised, tertiary veins distinct; petiole half-terete, 24-37 mm long, glabrous, slender. Inflorescences unknown. Flowers unknown. Fruits unknown.

Distribution. Although Litsea maingayi is known from Peninsular Malaysia and Sumatra, this different form is only known from Singapore.

Ecology. Growing in lowland forest.

Specimens examined. SINGAPORE: Chestnut Peninsula, 1 Jul 2015, Leong et al. SING2015193 (SING); Bukit Timah, 4 Apr 1941, Liew 37266 (SING).

Notes. This taxon is only known from sterile specimens which closely resemble Litsea maingayi. The status of this species cannot be confirmed until we have flowering and/ or fruiting material.

\section{Excluded names}

Litsea zeylanica Nees \& T.Nees, Cinnam. Disp. 1: 58-60, pl. 5 (1823); Ridley, J. Straits Branch Roy. Asiat. Soc. 33: $132(1900) .=$ Neolitsea zeylanica (Nees \& T.Nees) Merr., Philipp. J. Sci. 57 (1906). 
ACKNOWLEDGEMENTS. The author is grateful to the curators of A, BM, BO, E, G, GH, GZU, IBK, K, KEP, L, M, MEL, NY, P, PE, S, SING and US herbaria for access to and/or the loan of specimens used in the present study. Paul Athen from SING discussed various field characters and the Litsea ridleyi problem, Bazilah Ibrahim is thanked for all her help in SING, and Helen Fortune-Hopkins corrected my English. All drawings were made by Hazel Wilkes, photos by P.K.F. Leong, R.C.J. Lim \& X.Y. Ng. This research received support from the SYNTHESYS Project http://www.synthesys.info which is financed by the European Community Research Infrastructure Action under the FP7 “Capacities” Program. In addition, it was supported in 2015 and 2017 by a Visiting Research Fellowship at FRIM (Forest Research Institute Malaysia) and a Research Fellowship at the Singapore Botanic Gardens, which are gratefully acknowledged.

\section{References}

Blume, C.L. (1823). Catalogus van eenige der merkwaardigste zoo in- als uit-heemsche gewassen: te vinden in ,s Lands Plantentuin te Buitenzorg. Batavia.

Blume, C.L. (1826). Bijdragen tot de Flora van Nederlansch Indië. 11. Batavia: Ter Lands Drukkerij.

Blume, C.L. (1851). Museum Botanicum Lugduno-Batavum, vol. 1. Leiden: E.J. Brill.

Chong, K.Y., Neo, L., Tan, S.Y., Koh, C.Y., Lim, R.C.J., Loh, J.W., Ng, W.Q., Seah, W.W., Yee, A.T.K. \& Tan, H.T.W. (2016). Towards a field guide to the trees of the Nee Soon Swamp Forest (I): Lauraceae. Nat. Singapore 9: 1-28.

Corner, E.J.H. (1940). Wayside Trees of Malaya, vol. 1. Singapore: Government Printing Office.

Davison, G.W.H., Ng, P.K.L. \& Ho, H.C. (eds) (2008). The Singapore Red Data Book: Threatened Plants and Animals of Singapore, ed. 2. Singapore: Nature Society (Singapore).

De Kok, R.P.J. (2015). A revision of Cryptocarya (Lauraceae) from Thailand and Indo-China. Gard. Bull. Singapore 67: 309-350.

De Kok, R.P.J. (2016a). A revision of Cryptocarya R.Br. (Lauraceae) of Peninsular Malaysia. Kew Bull. 71: 7.

De Kok, R.P.J. (2016b). A revision of Beilschmiedia (Lauraceae) of Peninsular Malaysia. Blumea 61: 147-164.

De Kok, R.P.J. (2017). Two new records of Litsea (Lauraceae) from Singapore and the lectotypification of twenty-two names from several Lauraceae genera. Gard. Bull. Singapore 69: 167-177.

Gamble, J.S. (1910a). New Lauraceae from the Malayan region III. Bull. Misc. Inform. Kew 1910: 312-321.

Gamble, J.S. (1910b). New Lauraceae from the Malayan Region. IV. Bull. Misc. Inform. Kew 1910: 357-368.

Gamble, J.S. (1912). Materials for a Flora of the Malayan Peninsula no 22. J. Asiat. Soc. Bengal. 75: 1-204.

Hayata, B. (1915). Icones Plantarum Formosanarum, vol. 5. Taihoku: Bureau of Productive Industry, Government of Formosa.

Hooker, J.D. (1886). Flora of British India, vol. 5. London: L. Reeve \& Co.

IUCN Standards and Petitions Committee (2019). Guidelines for Using the IUCN Red List Categories and Criteria. Version 14. Prepared by the Standards and Petitions Committee. Available from: http://www.iucnredlist.org/documents/RedListGuidelines.pdf. 
Keng, H. (1990). The Concise Flora of Singapore: Gymnosperms and Dicotyledons. Singapore: Singapore University Press.

Kiew, R. \& Turner, I.M. (2003). Are any plants endemic to Singapore? Gard. Bull. Singapore 55: $173-184$.

Kochummen, K.M. (1989). Lauraceae. In: Ng, F.S.P. (ed.) Tree Flora of Malaya, vol. 4, pp. 98-178. Kuala Lumpur: Longman.

Kostermans, A.J.G.H. (1970). Materials for a revision of Lauraceae III. Reinwardtia 8(1): 21-196.

Lamarck, J.B.A.P.M. de (1792). Encyclopédie Méthodique Botanique, vol. 3: 361-759. Paris: Chez Panckoucke.

Le Cussan, J. \& Hyland, B.P.M. (2007). Lauraceae (excluding Cassytha). In: Wilson, A.J.G. (ed.) Flora of Australia, vol. 2, pp. 106-486. Melbourne: CSIRO Publishing.

Li, J., Christophel, D.C., Conran, J.G. \& Li, H.-W. (2004). Phylogenetic relationships within the 'core' Laureae (Litsea complex, Lauraceae) inferred from sequences of the chloroplast gene matK and nuclear ribosomal DNA ITS regions. Pl. Syst. Evol. 246: 19-34.

Li, X.W., Li, J., Huang, P.H., Wei, F.N., Cui, H.B. \& Van der Werff, H. (2008). Lauraceae. In: Wu, Z.Y., Raven, P.H. \& Hong, D.Y. (eds) Flora of China, vol. 7, pp. 102-254. Beijing: Science Press; and St Louis: Missouri Botanical Garden Press.

Loureiro, J. de (1790). Flora Cochinchinensis, vol. 1. Ulyssipone.

Meissner, C.D.F. (1864). Lauraceae. In: De Candolle, A. (ed.) Prodromus Systematis Naturalis, vol. 15, pp. 1-260. Parisii: Sumptibus Sociorum Treuttel et Würtz.

Miquel, F.A.W. (1855-1858). Flora van Nederlandsch Indie, vol. 1. Amsterdam: C.G. van der Post.

Nees von Esenbeck, C.G.D. (1832). Lauraceae. In: Wallich, N. (ed.) Plantae Asiaticae Rariores, vol. 3, pp. 30-32. London: Treuttel \& Würtz.

Nees von Esenbeck, C.G.D. (1836). Systema Laurinarum. Berolini: Sumptibus Veitii et Sociorum.

Ng, F.S.P. (2005). Taxonomic Notes on Bornean Litsea, Lindera, Neolitsea and Iteadaphne (Lauraceae). Gard. Bull. Singapore 57: 217-246.

Ngernsaengsaruay, C., Middleton, D.J. \& Chayamarit, K. (2011). A revision of the genus Litsea Lam. (Lauraceae) in Thailand. Thai Forest Bull., Bot. 39: 40-119.

Ridley, H.N. (1900). The Flora of Singapore. J. Straits Branch Roy. Asiat. Soc. 33: 27-196.

Ridley, H.N. (1913). An expedition to Mount Měnuang Gasing, Selangor. J. Linn. Soc., Bot. 41: $285-304$.

Ridley, H.N. (1920). New and rare plants from the Malay Peninsula. J. Fed. Malay States Mus. 10: $128-156$.

Ridley, H.N. (1924). The Flora of the Malay Peninsula, vol. 3. London: L. Reeve \& Co.

Ridley, H.N. (1925). The Flora of the Malay Peninsula, vol. 5. London: L. Reeve \& Co.

Rohwer, J.G. \& Rudolph, B. (2005). Jumping genera: the phylogenetic positions of Cassytha, Hypodaphnis, and Neocinnamomum (Lauraceae) based on different analyses of trnK intron sequences. Ann. Missouri Bot. Gard. 92(2):153-178.

Roxburgh, W. (1800). Plants of the Coast of Coromandel: Selected from Drawings and Descriptions Presented to the Hon. Court of Directors of the East India Company, vol. 2. London: W. Bulmer \& Co. Shakespeare Printing Office, for George Nicol.

Wallich, N. (1831). Lauraceae. In: Plantae Asiaticae Rariores, vol. 2, pp. 53-86. London: Treuttel and Würtz. 